\title{
WATER-RELATED SCIENTIFIC ACTIVITIES OF THE U.S. GEOLOGICAL SURVEY IN NEVADA, FISCAL YEARS 1985-89
}

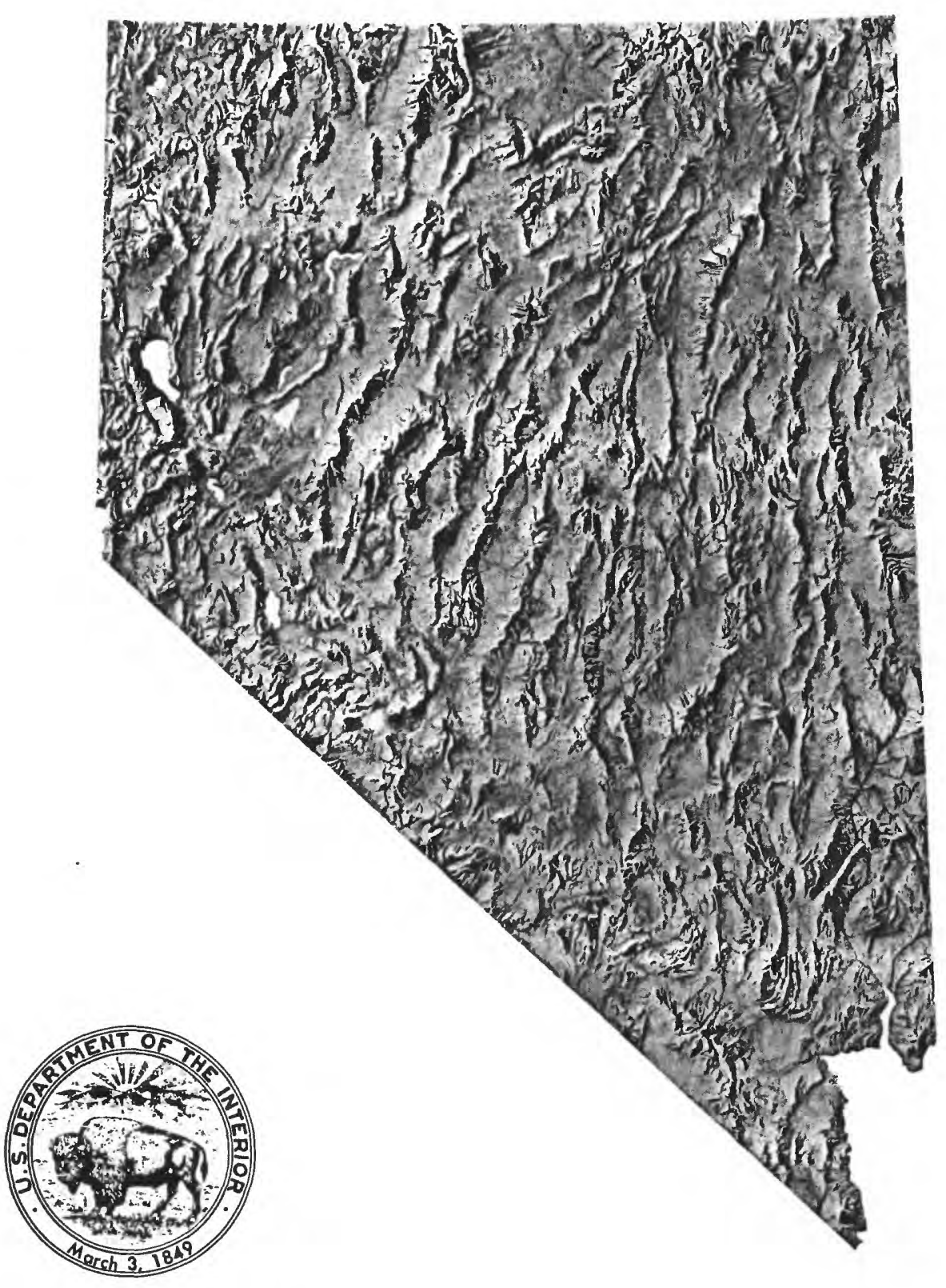

U.S. GEOLOGICAL SURVEY

Open-File Report 89-264 


\section{Water-Related Scientific Activities of the U.S. Geological Survey in Nevada, Fiscal Years 1985-89}

Compiled by Kathryn C. Kilroy

U.S. GEOLOGICAL SURVEY

Open-File Report 89-264 
DEPARTMENT OF THE INTERIOR

MANUEL LUJAN, JR., Secretary

U.S. GEOLOGICAL SURVEY

Dallas L. Peck, Director

For additional information write to:

U.S. Geological Survey Room 227, Federal Building 705 North Plaza Street Carson City, NV 89701
Copies of this report may be purchased from:

U.S. Geological Survey

Books and Open-File Reports Section

Federal Center, Building 810

Box 25425

Denver, CO 80225 


\section{CONTENTS}

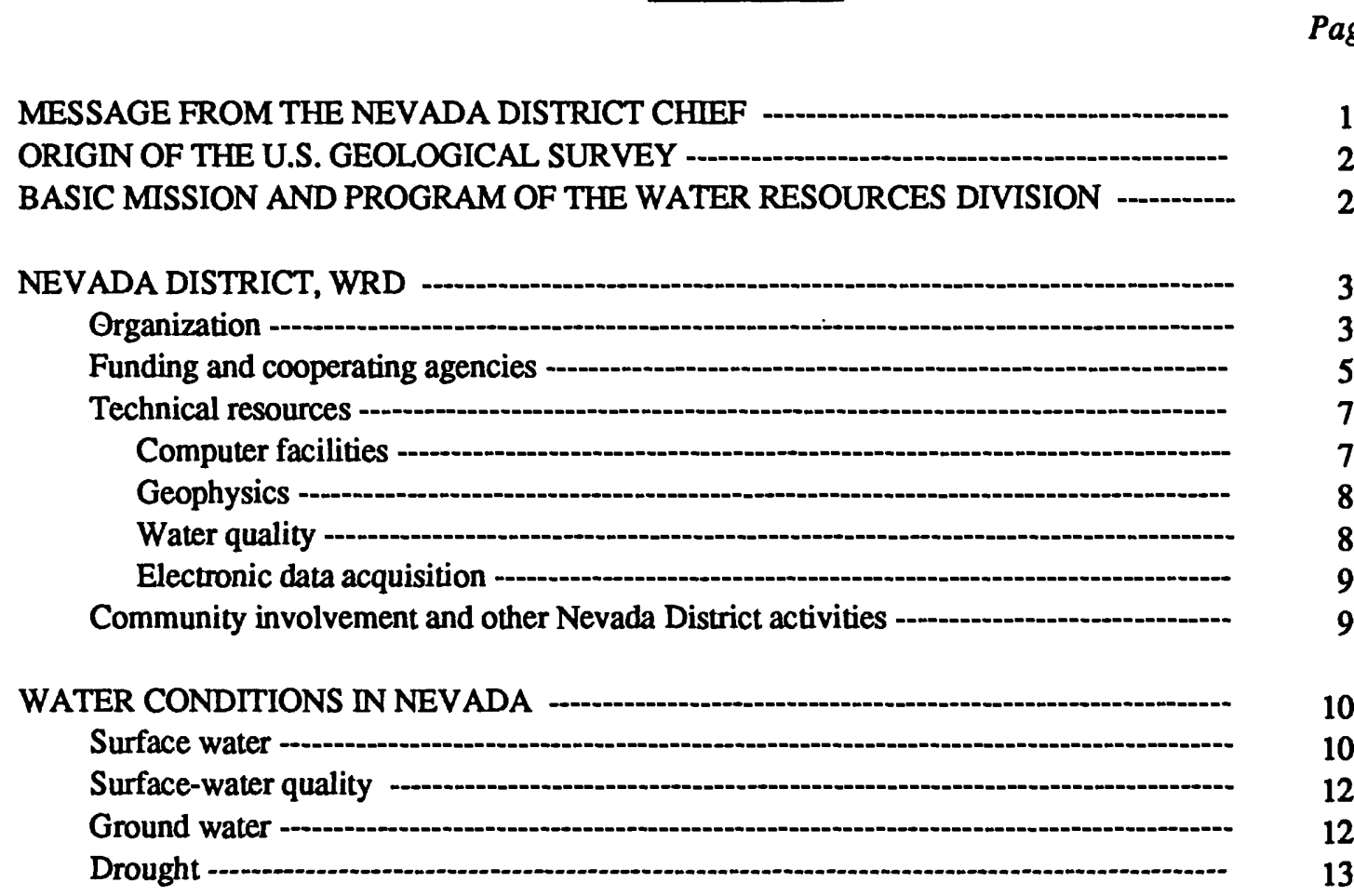

MAJOR WATER ISSUES IN NEVADA -.-.-.-. 13

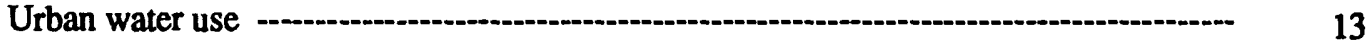

Water allocation in the Truckee-Carson River basin -

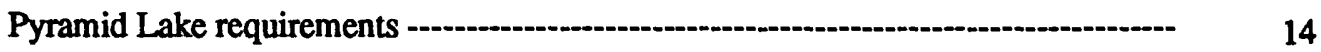

Irrigation-induced contamination at the Stillwater Wildlife Management Area ------ 14

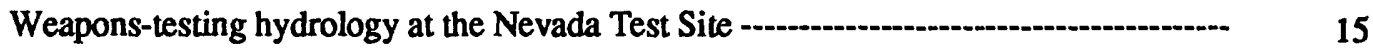

Proposed nuclear-waste repository at Yucca Mountain -

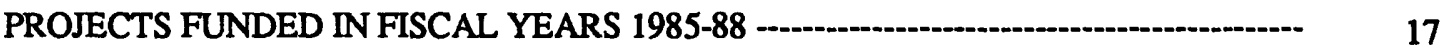

Surface-water data network (Project 001) - -

Ground-water data network (Project 002) -

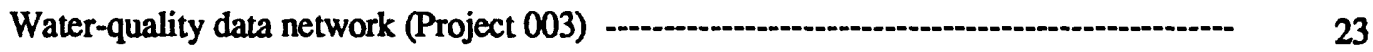

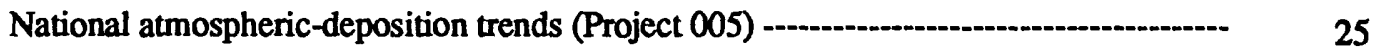

Flood-insurance studies (Project 006) -

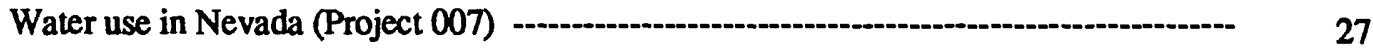

Flood investigations of Nevada streams (Project 036) --:-י-:- 28

Pumping effects on Devils Hole (Project 049) -

Environmental hydrologic studies (Project 056) --a-.- 31

Beatty disposal-site investigation (Project 072) -.-.-.-- 34 
PROJECTS FUNDED IN FISCAL YEARS 1985-88--Continued

Regional aquifer study of the Great Basin (Project 091) -....................................... 36

Carson Valley ground-water model (Project 096)

Flood and debris hazards at the Nevada Test Site (Project 105) -.......................-...- 41

Remote sensing in hydrology (Project 109) - -

Truckee River water-quality model (Project 111) -

Dendrohydrology (Project 112) -......- 46

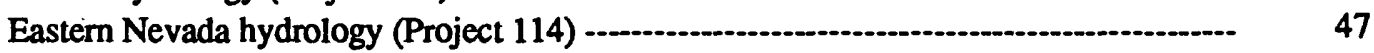

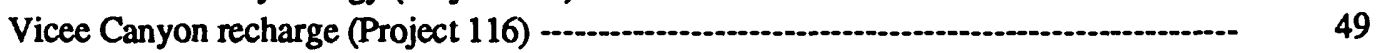

Evolution of Nevada water law (Project 118) -

Streamflow-network evaluation (Project 119) -

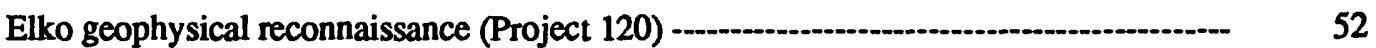

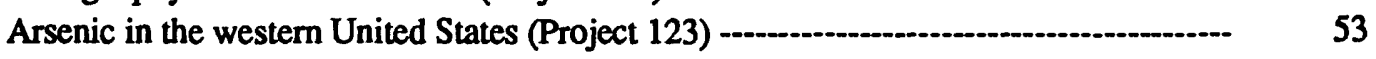

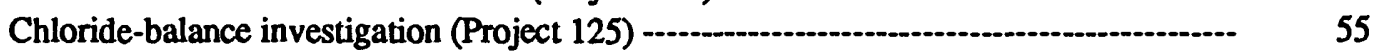

Ground-water model for Big Smoky Valley (Project 126) - -

Nevada carbonate-rock aquifers (Project 128) -

Ground-water studies, Lake Tahoe basin, Nevada (Project 129)

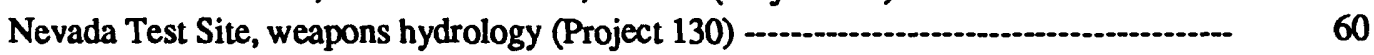

Water-resources evaluation of the Thousand Springs area (Project 131) -................... $\quad 62$

Ground-water data for Carson Valley (Project 132) -

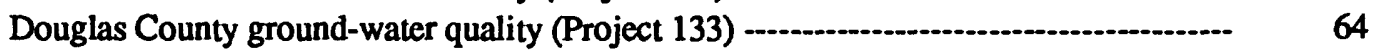

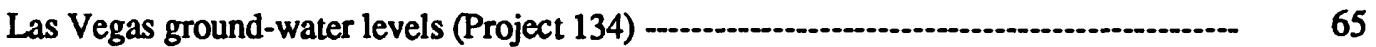

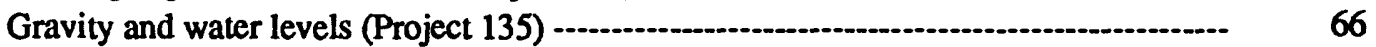

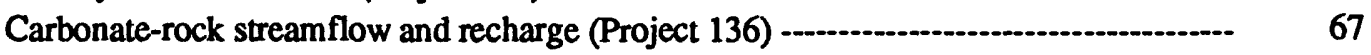

Las Vegas Wash studies (Project 137) - - 69

Southern Nevada hydrostratigraphy (Project 138) -

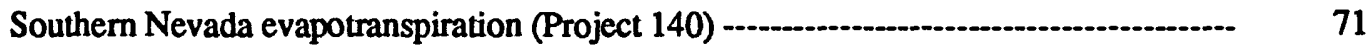

Ground-water quality in the Carson River basin (Project 142) ........................... 72

Reconnaissance study of irrigation drainage at the

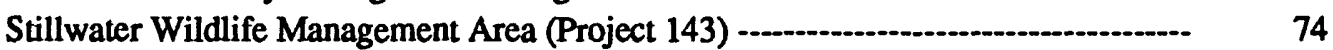

Ground-water study in Honey Lake Valley (Project 144) -............................... 75

Geographic-information system for the Carson River basin (Project 145) ---.-.---.-.-. 77

Geographic-information system for the Lake Tahoe basin (Project 146) -...-...-.-.-- 79

Stream monitoring in the Lake Tahoe basin (Project 147)

Detailed study of irrigation drainage at the

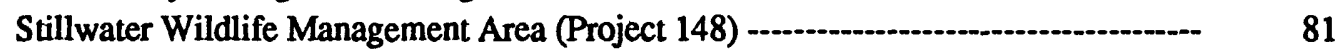

Effects of ground-water withdrawals on the Maggie Creek area (Project 149) -......-... $\quad 83$

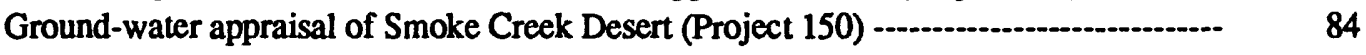

WATER-RELATED PUBLICATIONS, NEVADA DISTRICT, FISCAL YEARS 1985-88 - 86 SOURCES OF PUBLICATIONS AND INFORMATION 


\section{ILLUSTRATIONS}

Page

Figure 1. Chart showing Nevada District organizational structure

2. Map showing geographical areas of responsibility for basic-data collection by Nevada District field offices

3. Pie charts showing source of funds in fiscal years 1985-89 ...................... 5

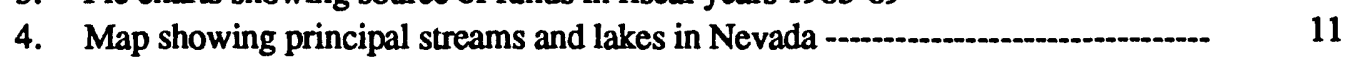

\section{TABLES}

Table 1. Nevada District budget, fiscal years 1985-89

2. Cooperating State and local agencies

3. Cooperating Federal agencies

\section{CONVERSION FACTORS AND ABBREVIATIONS}

"Inch-pound" units of measure used in this report may be converted to metric (International System) units by using the following factors:

\section{Multiply}

Acre foot (acre-ft)

Cubic foot per second $\left(\mathrm{ft}^{3} / \mathrm{s}\right)$

Foot (ft)

Inch (in.)

Mile (mi)

Square mile $\left(\mathrm{mi}^{2}\right)$
By

1,233

0.02832

0.3048

25.40

1.609

2.590
To obtain

Cubic meter $\left(\mathrm{m}^{3}\right)$

Cubic meter per second $\left(\mathrm{m}^{3} / \mathrm{s}\right)$ Meter (m)

Millimeter (mm)

Kilometer ( $\mathrm{km})$

Square kilometer $\left(\mathrm{km}^{2}\right)$

Fiscal Year and Water Year: Both comprise the 12-month period from October 1 through September 30, and are designated by the year in which that period ends (for example, Fiscal Year 1988 began October 1, 1987, and ended September 30, 1988).

Trade Names: The use of trade names in this report is for identification purposes only and does not constitute endorsement by the U.S. Geological Survey. 


\title{
Water-Related Scientific Activities of the U.S. Geological Survey in Nevada, Fiscal Years 1985-89
}

\author{
Compiled by Kathryn C. Kilroy
}

\section{- MESSAGE FROM THE NEVADA DISTRICT CHIEF}

The U.S. Geological Survey has been collecting water-resources data in Nevada since 1890. Most of the projects that constitute the current Nevada District program can be classified as either basic-data acquisition or hydrologic interpretation. About 25 percent of the program focuses on collection and dissemination of basic data on Nevada water resources, including operation of streamflow gages, ground-water level networks, and monitoring of the quality of the ground and surface water. The remaining 75 percent of our program involves interpretive hydrologic investigations and research.

About 52 percent of our activities are in cooperation with State and local agencies. Technical projects supported by other Federal agencies make up about 23 percent of the program, and the remaining 25 percent consist of USGS data collection, interpretive projects, and research.

Water conditions in Nevada during the 4 years covered by this report were by no means average, with one very wet year (1986) and two very dry years (1987 and 1988). As of April 1, it looks as if 1989 will be an approximately normal year for precipitation. During the past 4 years, the greatest variation from the average runoff (average discharge for each stream over the period of record) occurred in streams draining the Sierra Nevada. Streams draining the eastern and southern parts of the State were less affected.

The major water-resource issues facing the Nation today are water availability; competition for available water; deteriorating water-quality; optimal management of water resources; and climatic variation and its impact on water resources. Areas of concern in Nevada are directly related to the above issues, and include: water allocation in the Truckee-Carson River Basin; irrigation return-flow contamination of the Stillwater Wildlife Management Area; hydrologic effects of weapons testing at the Nevada Test Site; assessment of potential long-term impacts of the proposed Yucca Mountain Nuclear Waste Repository; and drought in Nevada.

Future water-resource issues in Nevada are likely to center on: water supply for, and the environmental effects of, the rapidly growing population centers at Las Vegas, Reno, and Elko; impacts of operations at the Nevada Test Site; management of interstate rivers such as the Truckee and Colorado Rivers; hydrologic and environmental impacts at heavily mined areas; and water-quality management in the Lake Tahoe Basin.

William J. Carswell, Jr. Nevada District Chief U.S. Geological Survey Water Resources Division Carson City, Nevada 


\section{ORIGIN OF THE U.S. GEOLOGICAL SURVEY}

The U.S. Geological Survey (USGS) was established by an act of Congress on March 3, 1879, to provide a permanent Federal agency to conduct the systematic and scientific "classification of the public lands, and examination of the geological structure, mineral resources, and products of national domain." An integral part of that original mission includes publishing and disseminating the earth-science information needed to understand, to plan the use of, and to manage the Nation's energy, land, mineral, and water resources.

Since 1879, the research and fact-finding role of the USGS has grown and been modified to meet the changing needs of the Nation it serves. As part of that evolution, the USGS has become the Federal Government's mapmaking agency, the primary source of data on the Nation's surface- and ground-water resources, and the employer of the largest number of professional earth scientists. Today's programs serve a diversity of needs and users.

\section{BASIC MISSION AND PROGRAM OF THE WATER RESOURCES DIVISION}

The mission of the Water Resources Division (WRD) is to provide the hydrologic information and understanding needed to manage the Nation's water resources for the benefit of the people of the United States. To accomplish this mission, the WRD, in cooperation with local, State, and Federal agencies, uses a wide variety of investigative and interpretive techniques to collect and transfer hydrologic information to the water-user community. An integral part of that mission includes publishing and disseminating the earth-science information needed to understand, to plan the use of, and to manage the Nation's energy, land, mineral, and water resources. The WRD undertakes this mission while adhering steadfastly to the concept of scientific method and the maintenance of an unbiased stance in the midst of often highly controversial political issues.

Programs sponsored by the WRD in Nevada include:

- Data collection to aid in the evaluation of the quantity, quality, and use of Nevada's water resources;

- Analytical and interpretive water-resources appraisals to describe the occurrence, quality, and availability of surface and ground water in Nevada;

- Basic and problem-oriented research into hydraulics, hydrology, and related fields of science and engineering;

- Public dissemination of water-resources data and results of water-resources investigations through reports, maps, computerized information services, and other forms of release;

- Scientific and technical assistance in hydrology to other Federal, State, and local agencies. 


\section{NEVADA DISTRICT, WRD}

\section{Organization}

The Nevada District Office is responsible for water-related U.S. Geological Survey activities in Nevada. The Nevada District has a staff of about 110 employees: about 85 in Carson City, about 22 in a field office in Las Vegas, and 3 in a field office in Elko. The Las Vegas office is scheduled to become a subdistrict office in the fall of 1989--an administrative change that will provide this rapidly growing part of the Nevada District greater autonomy and versatility. These staffing figures represent a nearly 100-percent increase over levels of 5 years ago and reflect a trend toward increased interest in State water-resource issues. Figure 1 shows the organization and responsibilities of the various units within the Nevada District. Basic data on water resources in Nevada are collected throughout the State by personnel from the field offices; figure 2 shows the areas of responsibility for each office.

Inquiries regarding projects described in this report may be directed to one of the following offices:

Nevada District Office 705 N. Plaza St., Room 224

Carson City, Nevada 89701
Las Vegas Field Office

1500 E. Tropicana Ave., Suite 201

Las Vegas, Nevada 89132
Elko Field Office

P.O. Box 1044

Elko, Nevada 89801

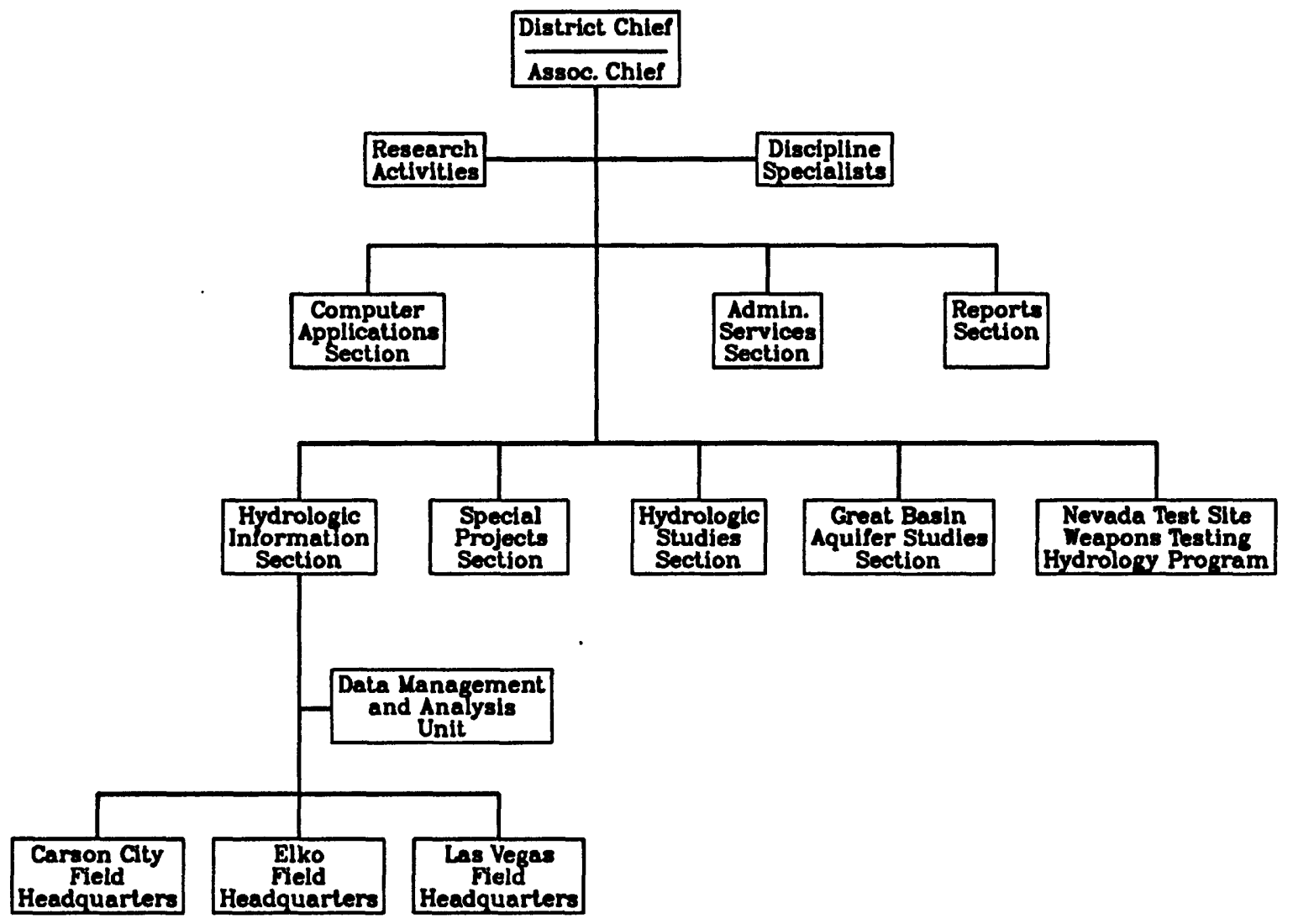

FIGURE 1.--Nevada District organizational structure. 


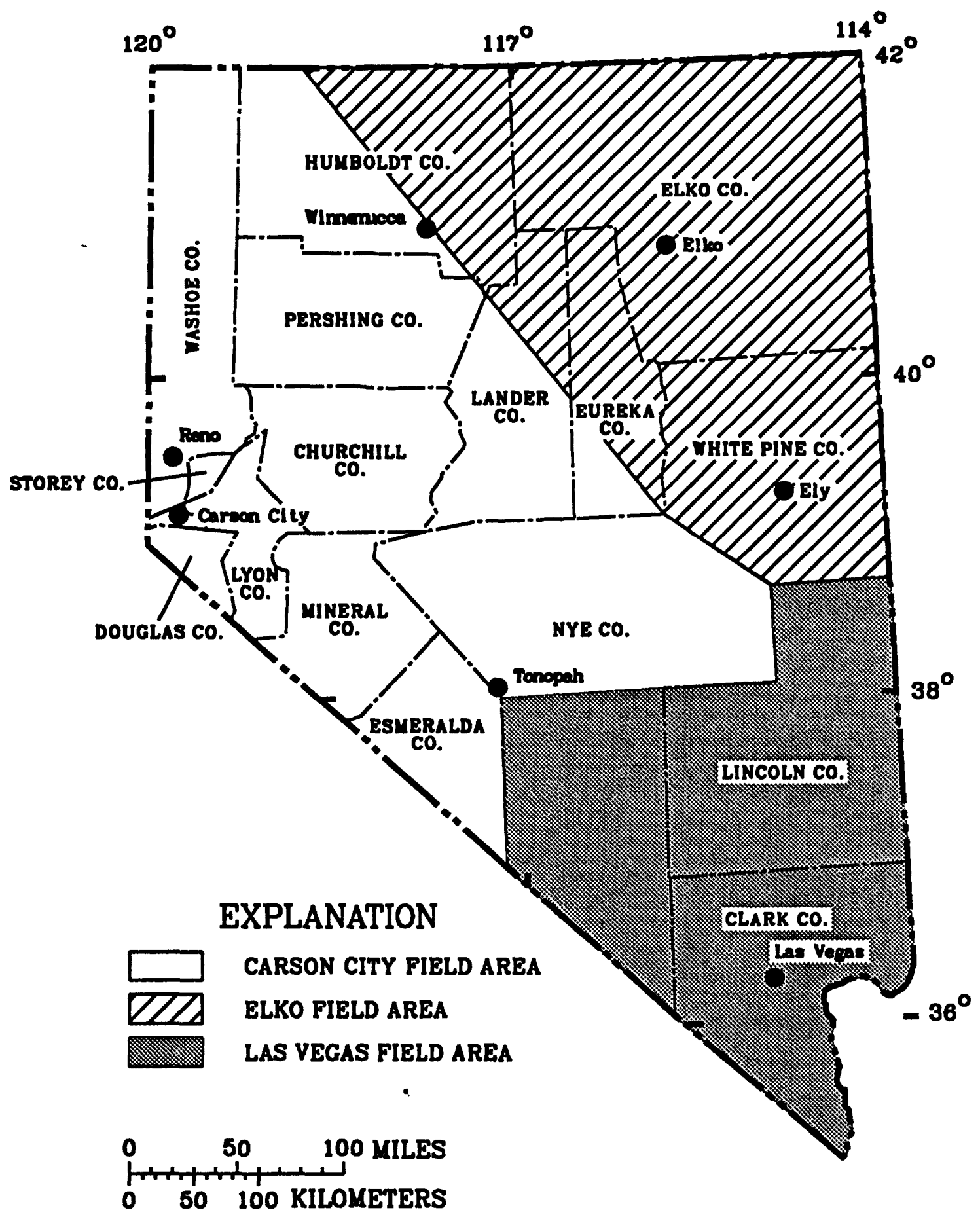

FIGURE 2.--Geographical areas of responsibility for basic-data collection by Nevada District field offices. 


\section{Funding and Cooperating Agencies}

Programs of the Water Resources Division in Nevada are funded as follows: (1) Federal Program-funding is appropriated directly to the U.S. Geological Survey by Congress for projects of national interest; (2) Cooperative Program--funding is shared equally between the USGS and interested State or local agencies; and (3) Other-Federal-Agencies Program--funding is supplied by Federal agencies requesting technical assistance from the U.S. Geological Survey. Total funds and sources of those funds for fiscal years 1985-88 and estimates for fiscal year 1989 are shown in figure 3 and listed in table 1. (The fiscal year extends from October 1 to September 30, and is designated by the calendar year in which it ends.) Total funds have increased from $\$ 3.7$ million in fiscal year 1985 to an estimated $\$ 5.9$ million for fiscal year 1989. A list of cooperating agencies active during the period 1985-88 is shown in table 2 and table 3.

FISCAL YEAR 1985 $\$ 3.7$ MILLION

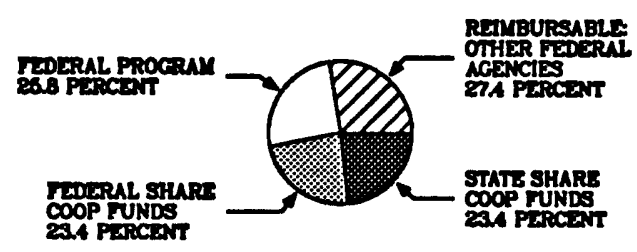

FISCAL YEAR 1987

$\$ 4.6$ MILLION

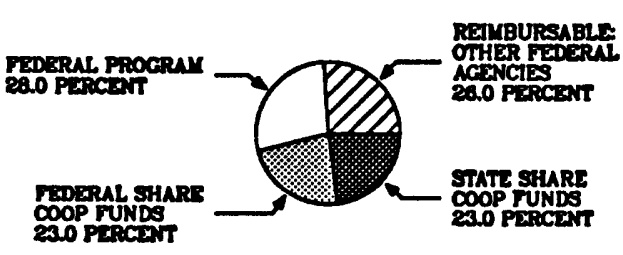

FISCAL YEAR 1986

$\$ 4.0$ MILLION

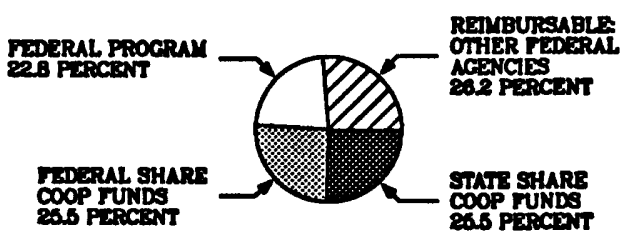

FISCAL YEAR 1988

$\$ 5.3$ MILLION

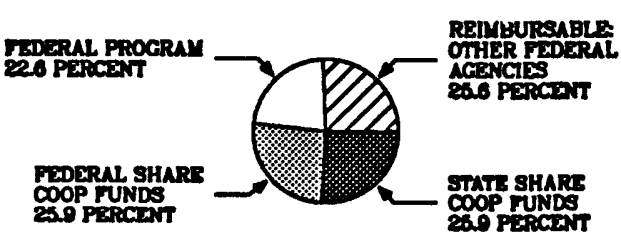

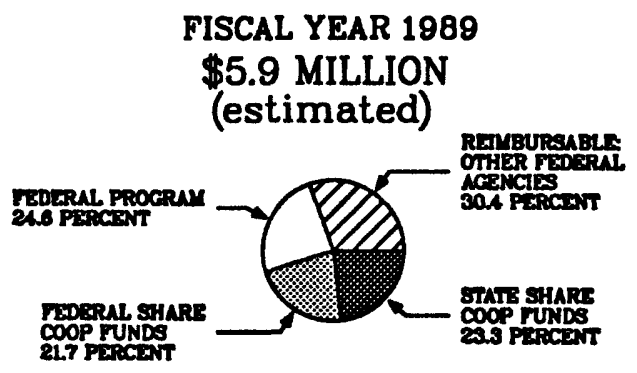

FIGURE 3.--Source of funds in fiscal years 1985-89. Proportion of total funds in each program category is shown. 
TABLE 1.--Nevada District budget, fiscal years 1985-89 (in thousands of dollars)

\begin{tabular}{|c|c|c|c|c|c|}
\hline & \multicolumn{5}{|c|}{ Fiscal year } \\
\hline & 1985 & 1986 & 1987 & 1988 & 1989E \\
\hline Federal Program Funds & \$ 961 & \$ 921 & $\$ 1,299$ & $\$ 1,201$ & $\$ 1,453$ \\
\hline $\begin{array}{l}\text { OFA Reimbursable Program } \\
\text { Cooperative Program }\end{array}$ & 1,016 & 1,052 & 1,197 & 1,357 & 1,791 \\
\hline Federal share & 861 & 1,015 & 1,053 & 1,378 & 1,280 \\
\hline State and local share & 861 & 1,015 & 1,053 & 1,378 & 1,280 \\
\hline Unmatched & 8 & 16 & 17 & 17 & 96 \\
\hline TOTAL FUNDING & $\$ 3,707$ & $\$ 4,019$ & $\$ 4,619$ & $\$ 5,331$ & $\$ 5,900$ \\
\hline
\end{tabular}

E, estimated.

TABLE 2.--Cooperating State and local agencies

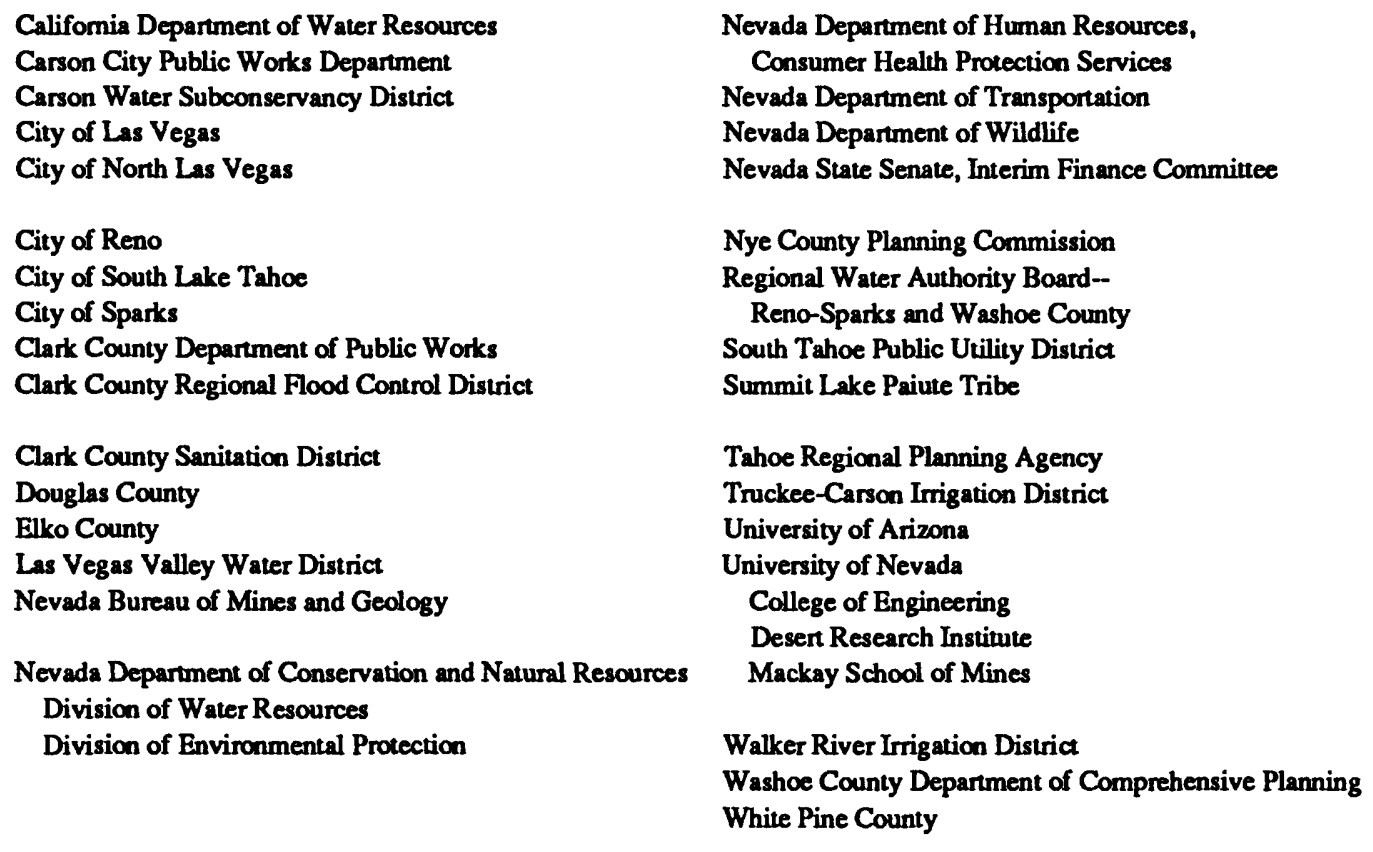


TABLE 3.--Cooperating Federal agencies

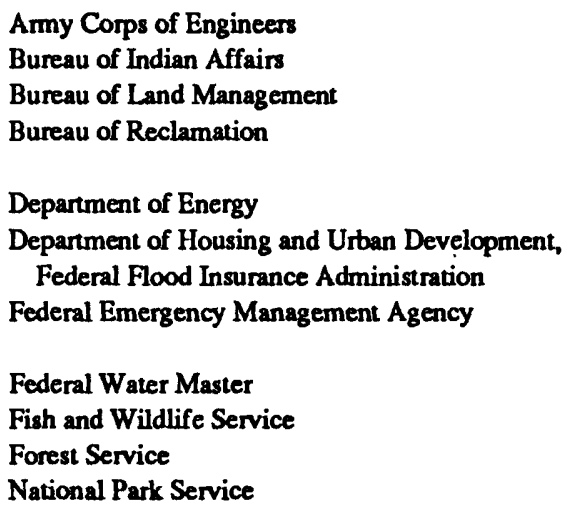

\section{Technical Resources}

\section{Computer Facilities}

The Nevada District operates a Prime 9955-II super minicomputer in the Carson City office to maintain computerized data bases; process graphic information; analyze remote-sensing imagery; run models; and perform word processing, computer graphics, mathematical processing, and a variety of other functions. This system is a node in the Distributed Information System of the Water Resources Division which links the U.S. Geological Survey headquarters in Reston, Va., with WRD offices across the Nation. Dedicated communication lines link the Nevada District field offices in Elko and Las Vegas, and offices of some cooperators, directly to the District Office in Carson City. The computer system supports more than 100 simultaneous-user processes. Peripheral hardware includes more than 3 giga bytes $(3,000,000,000$ bytes) of online high-speed disk storage, more than 80 user terminals; 8-inch to 36-inch plotters; large- and small-scale digitizers; mechanical and laser printers; flood-alert and real-time data networks; and mechanical- and digital-data recorders.

The primary storage function of the Nevada District computer system is to maintain the National WaterInformation System (NWIS) data bases. NWIS includes several subsidiary data bases: Automated Data Processing System (ADAPS), supporting continuous (hourly or more frequently) surface-water, ground-water, and water-quality data, Ground-Water Site Inventory (GWSI), Water Quality Database (QWDATA), and Water Use (WUSE). Information collected as part of basic-data programs and interpretive studies is stored in NWIS data bases at all WRD District offices. Data are aggregated in the National Water-Storage and Retrieval data base (WATSTORE), maintained on a large mainframe computer at U.S. Geological Survey headquarters in Reston.

The Nevada District computer system supports Geographic Information System (GIS) software and data bases. GIS technology integrates spatial descriptors (points, lines, and polygons) normally displayed as map features, with associated numerical and text data normally presented in tabular form (land-use, hydrographic characteristics, water quality, and other hydrologic data). The integrated system combines features of both computer-aided mapping systems and comprehensive relational data bases, and provides analytic, interpretive, and display capabilities that are difficult or impossible to achieve with conventionally structured data bases. The GIS can be directly linked to other computer systems, both within and outside the Nevada District. 
The computational functions of the Nevada District computer system are diverse. Generation of 2- and 3-dimensional models of complex hydrologic systems is perhaps the most demanding application. The complete system is capable of handling a variety of surface-water, ground-water, and climate models that include steady- and nonsteady-state simulations of hydraulic, water-quality, and biologic processes for a variety of boundary conditions.

Image processing of remotely sensed data for hydrologic studies is also done on the Nevada District computer system. Digital images from airborne and satellite-borne sensors are used to analyze and interpret rock, soil, vegetation, snow, open-water and other hydrologic characteristics. The images are capable of being integrated with basic data from NWIS and GIS data bases and with results from hydrologic and geophysical models. In-house image-processing facilities include both mini- and micro-computer hardware and software. Products can be generated at a variety of scales using local plotters, and large-format film processing is available through Regional USGS offices.

\section{Geophysics}

The Nevada District uses surface- and borehole-geophysical methods pertinent to hydrologic problems. A variety of surface-geophysical instrumentation, and computer software to process the data, are maintained within the District. Instrumentation includes two seismographs capable of monitoring "P" and "S" waves (reflection and refraction), two gravimeters, a magnetometer, and an electrical-resistivity array. In addition, a whole spectrum of geophysical instrumentation is available for District use at the national level: surface (electromagneto-tellurics, very low frequency, and resistivity); airborne (ground-penetrating radar, radiometrics, magnetics, and side-looking radar); and borehole (short- and long-normal resistivity, resistance, acoustic velocity, neutron, gamma density, natural gamma, temperature, flow meter, and televiewer).

\section{Water Quality}

Water-quality investigations are another important part of Nevada District operations. The District maintains mobile field laboratories with instrumentation for qualitative pesticide testing and to sample and analyze $\mathrm{pH}$, conductance, dissolved oxygen, stable and unstable isotopes, and for gas chromatography, immunoassays, and gas scintillation. Tracer studies can also be done with passive tracers (hydrogen, oxygen, carbon, chlorine, uranium isotopes) and active tracers (dyes, boron, salts). Limited inhouse facilities are maintained for sample preparation and storage, reagent preparation, bacterial analyses, and instrument calibration and repair. The USGS Water-Quality Laboratory in Arvada, Colo., which does production analyses and state-of-the-art research, is used for detailed laboratory analyses. Analytical support also is provided by cooperators and contract laboratories. 


\section{Electronic Data Acquisition}

Many studies undertaken by the Nevada District now involve some form of electronic data acquisition. Electronic field monitors and data loggers are used for continuous, fixed interval, and event monitoring or sampling in areas where frequent site visits are not practical. Electronic recording of water-quality data, water levels in wells and streams, and climatologic parameters related to evapotranspiration, are the most common applications.

Field monitors are being used to record water-quality parameters--pH, conductance, and dissolved oxygen-in studies such as at Stillwater National Wildlife Management Area. Hourly well-water levels are being electronically monitored in the eastern part of the State to determine aquifer response to earth-tide dilations. Two systems are used for remote transmission of data. Data-collection platforms transmit data to geosynchronous satellites that relay the data through the DIS computer network to the District data bases. Direct line-of-site radio telemetry is also in use, such as the Clark County Flood-Alert System that provides real-time monitoring of precipitation and streamflow for 17 sites. The District is actively using instrumentation and techniques for direct determination of bare-soil evaporation and transpiration, most of which is measured with electronic equipment.

\section{Community Involvement and Other Nevada District Activities}

As part of its responsibility to provide water-resources information to the public, the U.S. Geological Survey is involved in several activities other than data collection and hydrologic investigations.

Committee Involvement.--Members of the Nevada District staff serve on a wide variety of committees and advisory boards. Recent examples include: American Society of Testing Materials Standards Committees, Carson City Water Management Board, the Desert Research Institute Advisory Council on Water Resources Research, Federal-State Resource Action Council, Governor's Technical Advisory Committee for the Carson River, Reno Area Federal Executive Council, and the Truckee River Water Quality Technical Advisory Committee.

Environmental Impact Statements.--Staff members frequently review Environmental Impact Statements for Federal, State, and local agencies to verify the accurate interpretation of hydrologic data presented in the statements.

Education.--The Nevada District is involved in a continuing effort to actively participate in the educational community. Presentations on basic hydrology and general earth-science concepts are given at local schools, formal classes on hydrologic techniques are prepared for local universities, and students from universities, junior colleges, and high schools are employed in work-study programs.

Public Information.--The Nevada District serves as a focal point for the general public regarding map and earth-science questions. Staff members answer questions on regional hydrology and geology, basic-science concepts, USGS publications, and other related items. 


\title{
WATER CONDITIONS IN NEVADA
}

\author{
Surface Water
}

Most of Nevada is semi-arid to arid with little precipitation and stream runoff in most years.

Typically, as much as 75 percent of Nevada's precipitation falls during the winter months. Only the highest mountains produce more than 1 inch of average annual runoff. Three of the principal mountain sources of runoff are the Sierra Nevada, near the western boundary of the State, and the Ruby and Jarbidge Mountains in the northeast.

Nevada has no large rivers. The largest streams in the State are the Humboldt River, which drains the Ruby and Jarbidge Mountains; the Truckee, Carson, and Walker Rivers, which drain parts of the Sierra Nevada; and the Muddy and Virgin Rivers, which flow into the Colorado River in the southeast part of the State (figure 4). Many of these rivers are controlled by dams, reservoirs, and diversions. Of the mentioned rivers, only the Humboldt and Muddy Rivers begin and terminate within Nevada.

Surface-water conditions for water year 1985 (October 1, 1984, through September 30, 1985) were dominated by greater-than-average winter snowfalls, an unusually early spring melt, and a dry summer. The net result was that annual streamflow for streams draining the eastern Sierra Nevada was about 70 percent of the long-term average. Streams draining the eastern part of the state had approximately average streamflow, and the Colorado River, although controlled, discharged at 186 percent of its long-term (1935-88) annual average.

Streamflow in central and southern Nevada was average or below average during water year 1986. Northern and western Nevada, however, experienced an unusual 9-day wet period from February 12 to 20. The Humboldt, Truckee, Carson, and Walker Rivers all flowed at over 175 percent of their long-term annual averages. Extensive flooding occurred in towns along the eastern flank of the Sierras during this period.

Except for the Colorado River, which discharged at 128 percent of its long-term average, all major streams in Nevada had less-than-average streamflow for the 1987 water year. The Humboldt River had an annual streamflow of only 42 percent, and the rivers draining the Sierra Nevada discharged at $40-70$ percent of their long-term averages. The Virgin River discharged at 75 percent of its average annual streamflow.

Drought conditions continued in the 1988 water year throughout the State as the usually heavy snows of late winter failed to arrive. The Colorado River discharge was near average as water stored in upstream reservoirs from earlier, wetter years was used to supplement natural streamflow. Rivers draining the Sierra Nevada discharged at 30-50 percent, and the Humboldt River discharged at 40 percent of its long-term (19021988) average-annual streamflow. 


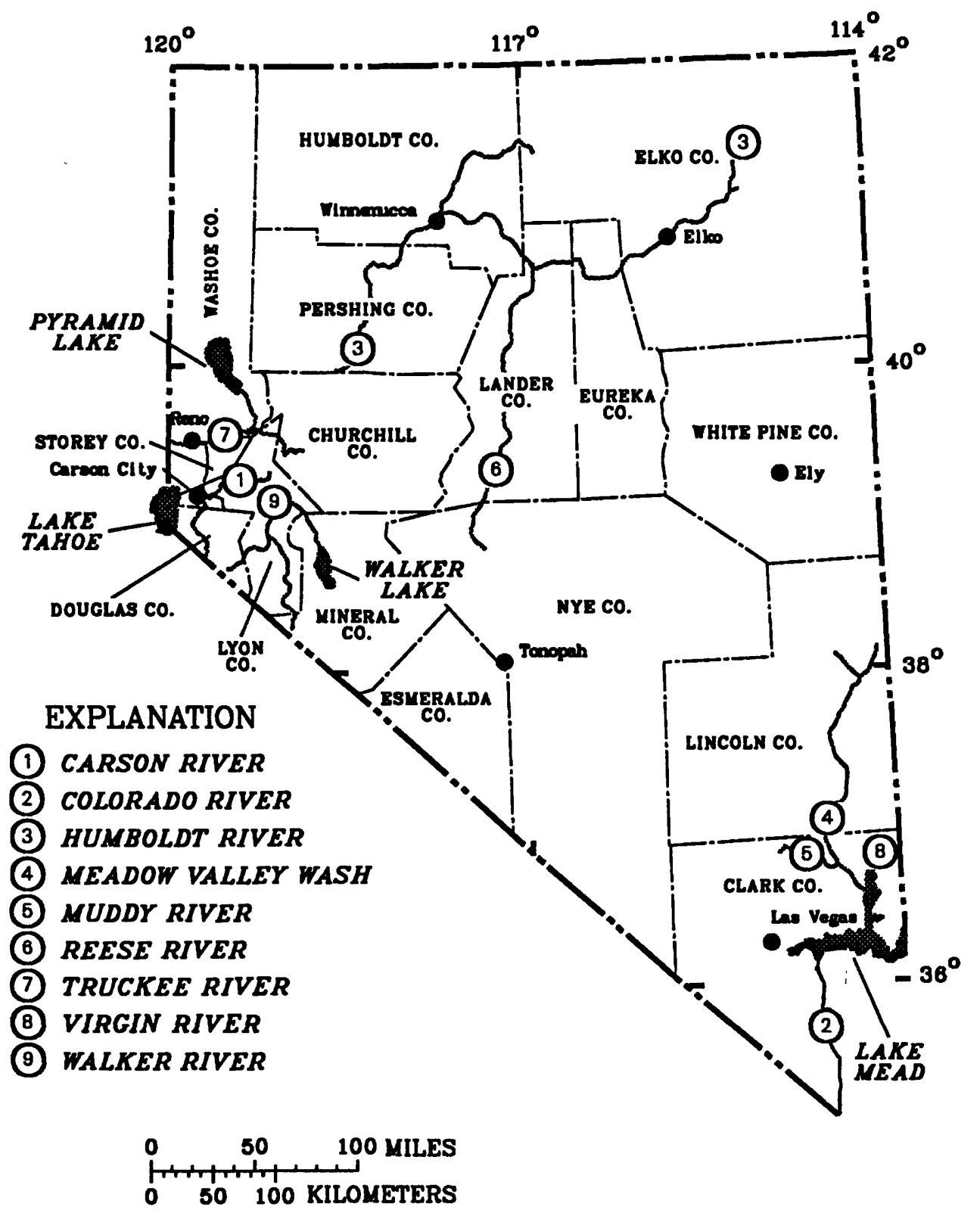

FIGURE 4.--Principal streams and lakes in Nevada. 


\section{Surface-Water Quality}

The quality of surface water in Nevada varies greatly from place to place, as well as seasonally. Concentrations of dissolved solids are generally higher in the southern part of the State than in the north part, and are dependent to a large extent on water discharge. Concentrations usually are greatest during periods of low streamflow, and lowest during periods of high streamflow due to dilution by precipitation or snowmelt runoff.

Surface-water quality did not change significantly in most streams during the period 1985-88; however, a few areas did gain notoriety. High mercury concentrations, probably as a result of 19 th-century mining operations in the Comstock Lode near Virginia City, were detected in the lower Carson River and Lahontan Reservoir sediments. Urbanization in the Las Vegas Metropolitan area greatly accelerated erosion and increased sediment transport in Las Vegas Wash. Increased discharge during the 1985-88 period also caused a decrease in dissolved-solids concentrations in lower Las Vegas Wash near Boulder City and the Colorado River below Hoover Dam. Conversely, high concentrations of dissolved solids in the Virgin River near Littlefield are probably related to low flows in recent years.

\section{Ground Water}

Development of ground-water supplies continued in Nevada during 1985-88 as drillers' logs of approximately 5,000 wells were submitted to the State Engineer's Office. The number of logs submitted increased at an annual rate of approximately 20 percent. Of the logs submitted during this period, approximately three-fourths were from wells drilled for domestic use. The remainder were from wells drilled for exploration, industrial and public supply, and irrigation use. Well drilling was concentrated in the northwestern and southern parts of the State, particularly near the cities of Reno and Las Vegas.

As in the past, most wells were drilled into unconsolidated deposits of sand, gravel, silt, and, less commonly, clay that partly fill the numerous basins in Nevada. Most development is in the basins, where water is readily obtained from relatively shallow depths in unconsolidated deposits, and where well yields are more predictable than in the mountains. Consolidated igneous, metamorphic, and sedimentary rocks underlie the basins and crop out in adjacent mountains. Some consolidated rocks, particularly those that are fractured, can yield substantial quantities of water. Development of consolidated rock aquifers became more common during the period $1985-88$ than previously.

Ground-water levels fluctuate in the short and long term in response to seasonal and climatic changes in recharge and discharge. Water levels generally rise from late winter to early summer in response to runoff from snows in the mountains and generally decline during the summer to early winter, when recharge is small and discharge by evapotranspiration and pumping is large. Long-term climatic changes can also affect water-level trends over a period of years. Many wells in the State experienced water-level declines during the 1970's, small inclines during the early 1980's, and further declines during the 1985-88 period of interest. 


\section{Drought}

The winter of 1987-88 marked the second consecutive year of deficient precipitation in Nevada, a drought that has essentially equaled that of 1977-78. During the period 1985-88, the greatest departures in runoff from the average occurred in rivers draining the Sierra Nevada. Streams draining the eastern and southern parts of the State were less affected. As of April 1, 1989, the snowpack in the Sierra Nevada was at nearly 100 percent of its average water content for this time of year. However, streams and reservoirs are so depleted after two dry years in a row, that the Nevada State Climatologist has estimated 150-200 percent of average annual runoff would be needed just to fill them to normal levels (written communication, 1989). The problem is exacerbated by increased water demand due to growth in the State's population during the last decade.

\section{MAJOR WATER ISSUES IN NEVADA}

\section{Urban Water Use}

The population in Nevada increased by more than 63 percent in the 1970's, and growth has continued at a slightly slower pace through 1988. The major growth centers in Nevada are the northwest (Reno-Sparks, Carson City, and Minden-Gardnerville), the southeast (Las Vegas), and the mining districts near Elko.

The Truckee River--which flows from Lake Tahoe, through the Reno-Sparks metropolitan area to Pyramid Lake--is the major source of water for the Reno-Sparks area. Water rights for the Truckee River are entirely allocated, water-use restrictions have been imposed in the metropolitan area for three out of the past four summers, and few local resources are left to support the continuing population growth. This has prompted the search for ground-water sources in an ever-widening region of northwestern Nevada.

Las Vegas has two sources of water supply: Lake Mead and the basin-fill aquifer beneath the city. Water levels in the basin-fill aquifer near city wells have declined as much as 50 feet since 1985, with seasonal fluctuations of approximately 30 feet. The Colorado River water stored in Lake Mead is fully allocated, with approximately 300,000 acre-feet set aside for Las Vegas. Currently, this allocation is not being fully utilized; however, population growth and the associated demand for water is expected to exceed this allocation within the next decade. An alternative source of ground water is currently (1989) being sought.

The Elko-Carlin area, although less densely populated than major cities of the State, is experiencing the most rapid growth rate. Both towns derive 100 percent of their water from wells in basin-fill aquifers. Elko has already replaced one city well because drawdown in the aquifer exceeded the working depth of the well, but the most pressing water-related problem at present is inadequate sewage facilities.

The Nevada District currently is involved in four projects that address the issue of water resources near urban areas. Ground-water appraisals are being made of Honey Lake Valley and Smoke Creek Desert north of Reno, of the southern Nevada carbonate-rock aquifers near Las Vegas, and of pumping effects on the Maggie Creek area near Carlin. Three other projects completed during 1985-88 include a ground-water assessment of Carson Valley, a recharge study at Vicee Canyon near Carson City, and a well-recovery test in Las Vegas. The issue of urban water use is also being addressed by a project to identify, quantify, and catalog all types of consumptive water use throughout Nevada. 


\title{
Water Allocation in the Truckee-Carson River Basin
}

\begin{abstract}
Allocation of surface water in the Truckee and Carson River basins of California and Nevada has been in litigation since the late 1800 's. Basic issues involve division of the resources between the States, and competing demands in Nevada among: (1) urban use in the booming Reno-Sparks area (mid-basin); (2) Indian and endangered-species fishery requirements at Pyramid Lake (terminus of Truckee River); and (3) irrigation, fish, and waterfowl demands in Fallon and the Stillwater Wildlife Management Area (WMA).
\end{abstract}

Water allocation in the Truckee and Carson Rivers is managed under a number of Federal Court decrees by an "interim" (since the mid '30s) Federal Water Master. Major reservoirs and diversions on the Truckee and lower Carson Rivers are U.S. Bureau of Reclamation (USBR) projects, but most are operated under contract by the Truckee Carson Irrigation District (TCID).

The Nevada District operates 31 streamflow gaging stations and 6 water-quality monitoring stations in the Truckee and Carson River basins. The Truckee River water-quality assessment program developed a calibrated daily nutrient and oxygen model for the Truckee River to address some of the water-quality issues and began to develop, but did not have funds to complete, a daily streamflow model for the two rivers. Unfortunately, current data-collection networks are insufficient in spatial and temporal density to calibrate a comprehensive management model for operation of this important river system.

\section{Pyramid Lake Requirements}

In response to the Pyramid Lake Indian Tribe and U.S. Fish and Wildlife Service legal challenges, the USBR has promulgated a new set of Operating Criteria and Practices for the TCID Truckee River diversions. The result will significantly reduce streamflow diversion to the Newlands Irrigation Project at Fallon in favor of increased flows to Pyramid Lake.

\section{Irrigation-Induced Contamination at the Stillwater Wildlife Management Area}

The Stillwater WMA is 1 of 13 international shore-bird preserves in the western hemisphere. Irrigation drainage from the Newlands Irrigation Project, which contains elevated concentrations of dissolved solids and potentially toxic trace elements, is the principal source of water to the Stillwater WMA. In a physical environment having some similarities to the Kesterson area in California, contaminants that have exceeded biological criteria include selenium, arsenic, boron, and mercury. Many fish and birds have died during the past year (1988) in the area, although direct links to a specific water-quality constituent have not been established.

The water-supply and water-quality issues are complicated by legal and environmental pressures on USBR to reduce diversions from the Truckee River to the Newlands Project, potentially resulting in greatly reduced inflows to the Stillwater WMA. Among the solutions being proposed to guarantee a secure water supply to the Stillwater WMA is the purchase of irrigation water rights by wildlife interests. 
Nevada District project activities in the area include the ongoing Stillwater Irrigation Drainage Project of the U.S. Department of the Interior, the National Water-Quality Assessment pilot ground-water study of the Carson River basin, and a Geographic Information System study of the Carson River basin.

\section{Weapons-Testing Hydrology at the Nevada Test Site}

The Nevada District provides support to the U.S. Department of Energy by studying the hydrologic impacts of weapons testing. Nuclear weapons have been tested at the Nevada Test Site (NTS) since the 1940's. The site was chosen because of its remote location, government ownership, and interior drainage system (Great Basin). Long-term studies of basin-and-range hydrology have identified regional aquifers that may allow migration of radionuclides out of the NTS. However, no study to date has shown that such migration is occurring, nor has any conclusively shown that it is not.

\section{Proposed Nuclear-Waste Repository at Yucca Mountain}

In December of 1987, the U.S. Congress identified Yucca Mountain as a potential site for the Nation's first high-level nuclear-waste repository. The planned repository is scheduled to be completed by 2010 and would be expected to contain nuclear waste for at least 10,000 years. About 22,000 tons of waste currently are stored at reactor sites throughout the country, and all of it is targeted for the selected repository. The repository's ultimate capacity is expected to be about 96,000 tons.

The Nevada District assists the Yucca Mountain Project Branch by studying the paleohydrology and flooding potential in the Yucca Mountain area. The District also operates data-monitoring networks to support individual Yucca Mountain Project studies of unsaturated and saturated ground-water flow. 


\section{PROJECTS FUNDED IN FISCAL YEARS 1985-88}

$-17-$

(p.19 follows) 


\section{Surface-Water Data Network (Project 001)}

Location: Statewide in Nevada and eastern California.

Project Chief: Alex Pupacko.

Period of Project: Continuous since 1894.

Cooperating Agencies: California Department of Water Resources, Carson Water Subconservancy District, Carson City Public Works Department, City of Las Vegas, City of Reno, City of Sparks, Douglas County, Nevada Department of Conservation and Natural Resources, Nevada Department of Transportation, South Tahoe Public Utility District, Summit Lake Paiute Indian Tribe, Truckee-Carson Irrigation District, U.S. Army Corps of Engineers, U.S. Bureau of Indian Affairs, U.S. Bureau of Land Management, U.S. Bureau of Reclamation, Federal Water Master, U.S. Board of Water Commissioners, Walker River Irrigation District, and Regional Water Authority Board--

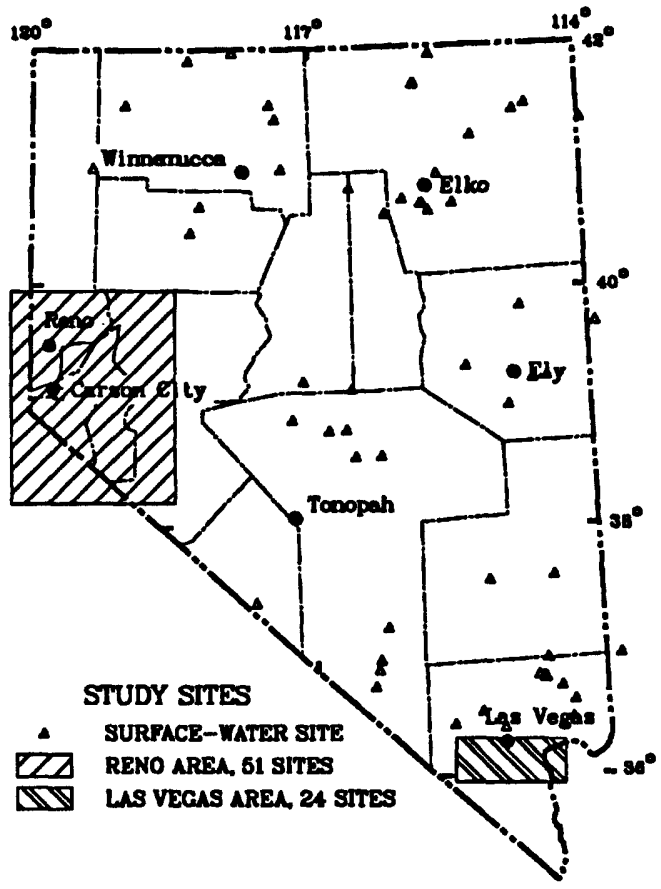
Reno-Sparks and Washoe County.

Problem: Surface-water runoff is highly variable, both areally and seasonally, throughout the State. Information is needed for purposes of surveillance, planning, design, hazard warning, and management. These data are particularly relevant to water-related fields such as water supply, hydroelectric power, flood control, irrigation, bridge and culvert design, wildlife management, pollution abatement, floodplain management, and water-resources development. An appropriate data base is necessary to support such ongoing needs.

Objectives: A network of surface-water stations is maintained to collect data needed for: (1) assessment of water resources; (2) operation of reservoirs and industries; (3) waste disposal and pollution control; (4) water-quality estimations; (5) compact and legal requirements; (6) analysis of temporal variability and long-term trends for forecasting; and (7) research.

Approach: The stage and discharge of lakes and streams are measured using standard U.S. Geological Survey methods. Data-collection intervals are determined by the principal purpose of each site.

Progress and Significant Results, Fiscal Years 1985-88: Continuous streamflow monitoring at 88 sites, including 83 year-round and 5 irrigation-season stations continued throughout 1985-87. Year-round sites were increased to 121 and irrigation-season sites increased to 10 in 1988. In addition, stage measurements were made at 21 lakes and reservoirs. All data were processed and are stored in the NWIS computer data base.

Plans for Fiscal Year 1989: Statewide surface-water data collection, computation, and compilation will be continued. Field surveys and computations for indirect measurements of flow where gages have not yet been located will be made as needed. A flood-alert system will be expanded in the Las Vegas area. The 1988 data report will be completed and published. 


\section{Publications, Fiscal Years 1985-88:}

Frisbie, H.R., La Camera, R.J., Riek, M.M., and Wood, D.B., 1984, Water-resources data for Nevada, water year 1983: U.S. Geological Survey Water-Data Report NV-83-1, 328 p.

----1985, Water-resources data for Nevada, water year 1984: U.S. Geological Survey Water-Data Report NV-84-1, $247 \mathrm{p}$.

-.--1985 [1988], Water-resources data for Nevada, water year 1985: U.S. Geological Survey Water-Data Report NV-85-1, 255 p.

Pupacko, Alex, La Camera, R.J., Riek, M.M., and Wood, D.B., 1988, Water-resources data for Nevada, water year 1986: U.S. Geological Survey Water-Data Report NV-86-1, 263 p.

Pupacko, Alex, La Camera, R.J., Riek, M.M., and Swartwood, J.R., (in press), Water-resources data for Nevada, water year 1987: U.S. Geological Survey Water-Data Report NV-87-1. 


\section{Ground-Water Data Network (Project 002)}

Location: Statewide.

Project Chief: James R. Swartwood, 1988-89;

David B. Wood, 1985-87;

Period of Project: Continuous since 1945.

Cooperating Agencies: Carson City Public Works Department, Carson Water Subconservancy District, Elko County, Las Vegas Valley Water District, Nevada Division of Water Resources, and Nevada Bureau of Mines and Geology.

Problem: The long-term response of regional aquifers throughout the State to natural climatic variations and induced stresses is largely unknown. Proper planning and management of State water resources requires long-term information so that trends can be defined, problems ascertained, and ameliorative actions taken. Measurements of recharge to and discharge from ground-water systems provide a data base from which to evaluate the effects of management and development, and assist in the prediction of future supplies.

Objectives: Long-term records will be kept to determine if any long-term trends in ground-water levels are occurring within the State. The long-term data will also be used as a base against which short-term data from local studies can be compared. The data will serve as a management tool for national, State, and local planners.

Approach: A regionally representative network of wells is maintained to allow measurement of water levels in most basin-fill aquifers within the State. The wells are situated, if possible, away from areas of human impact such as communities, agriculture, or industry. Measurements are made at approximately the same time of year to reduce seasonal effects. New wells will be added to the network as old wells are destroyed, local land use changes, or as other needs arise.

Progress and Significant Results, Fiscal Years 1985-88: A formal program was initiated, in cooperation with the Nevada Division of Water Resources (NDWR), to develop a computer data base to store and retrieve Nevada well-log data (exclusive of lithology); data have been entered for wells completed since 1985. Data bases have also been developed for ground-water pumpage data, supplied by local utilities and NDWR since January of 1985. The GWSI data base for Nevada was moved from a national site to the Carson City office in the spring of 1986. The observation-well network was rearranged in 1988 to include 409 wells (including 2 with continuous recorders) and 40 springs.

Plans for Fiscal Year 1989: Ground-water data collection, computation, and compilation will be continued. Further cooperative computer data bases will be developed by both the USGS and NDWR. The 1988 waterdata report will be compiled and published. 
Publications, Fiscal Years 1985-88:

Frisbie, H.R., La Camera, R.J., Riek, M.M., and Wood, D.B., 1984, Water-resources data for Nevada, water year 1983: U.S. Geological Survey Water-Data Report NV-83-1, 328 p.

-----1985, Water-resources data for Nevada, water year 1984: U.S. Geological Survey Water-Data Report NV-84-1, $247 \mathrm{p}$.

--.--1985 [1988], Water-resources data for Nevada, water year 1985: U.S. Geological Survey Water-Data Report NV-85-1, 255 p.

Pupacko, Alex, La Camera, R.J., Riek, M.M., and Wood, D.B., 1988, Water-resources data for Nevada, water year 1986: U.S. Geological Survey Water-Data Report NV-86-1, 263 p.

Pupacko, Alex, La Camera, R.J., Riek, M.M., and Swartwood, J.R., (in press), Water-resources data for Nevada, water year 1987: U.S. Geological Survey Water-Data Report NV-87-1.

Wood, D.B., (in press), Water-level changes associated with ground-water development in Las Vegas Valley, Nevada, 1978-79: Nevada Division of Water Resources, Information Report 30.

-.--(in press), Water-level changes associated with ground-water development in Las Vegas Valley, Nevada, 1979-81: Nevada Division of Water Resources, Information Report 31. 


\section{Water-Quality Data Network (Project 003)}

Location: Statewide.

Project Chief: Richard J. LaCamera

Period of Project: Continuous since 1939.

Cooperating Agencies: City of Las Vegas, City of Reno, Nevada Division of Water Resources, and U.S. Bureau of Land Management.

Problem: The physical, chemical, and biological quality of surface water is highly variable and must be monitored and defined to enable sound management and planning. This requires a long-term data base of standardized water-quality information so that local influences, seasonal trends, sampling variability, and long-term trends may be distinguished.

Objectives: Evaluation of regional water quality requires a base knowledge of spatial and temporal

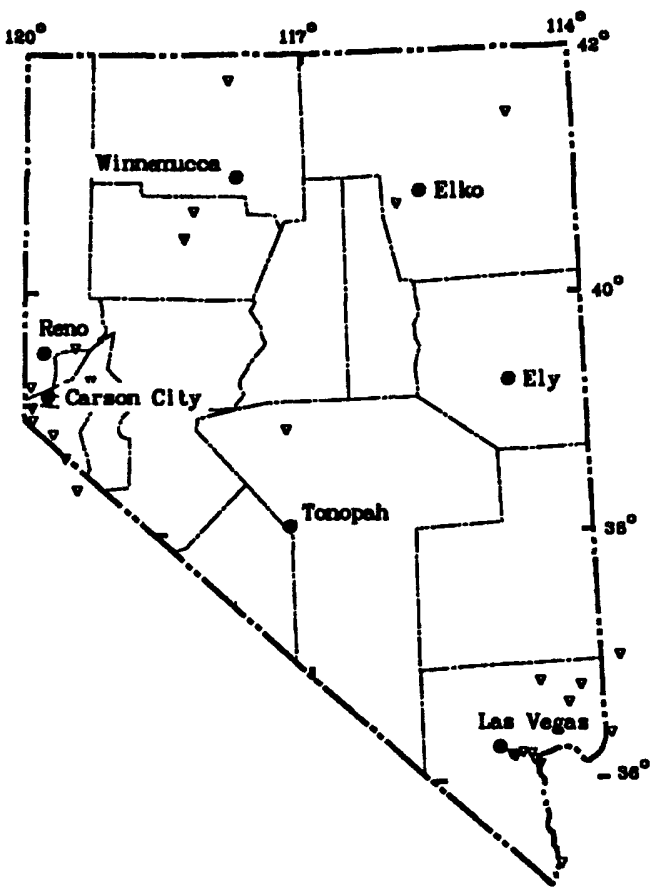
variability and trends with which to compare current conditions. The data will allow distinction of short-term and long-term trends, provide an early warning of developing water-quality problems, and provide data for Federal management of interstate waters. It will also serve as a management tool for national, State, and local planners.

Approach: A network of water-quality stations for surface water has been established to provide information about variation in sediment loads and physical, chemical, and biological characteristics. Standard USGS methods of water-sample collection, preservation, and analysis are used.

Progress and Significant Results, Fiscal Years 1985-88: The data-collection network was reduced during 1985 to 1987 primarily due to funding limitations. Since 1987, the network has increased by about one third, to address additional regional water-quality concerns. Currently (fiscal year 1989), there are 30 active sites (28 year-round sites and 2 irrigation-season sites) in the network. All data were stored in NWIS. Water-data reports for 1984-87 were completed.

Plans for Fiscal Year 1989: The present network will continue. The quality of data collection and analysis will continue to be improved as a result of better equipment and sampling techniques. The 1988 water-data report will be compiled and published. 
Publications, Fiscal Years 1985-88:

Frisbie, H.R., La Camera, R.J., Riek, M.M., and Wood, D.B., 1984, Water-resources data for Nevada, water year 1983: U.S. Geological Survey Water-Data Report NV-83-1, 328 p.

----1985, Water-resources data for Nevada, water year 1984: U.S. Geological Survey Water-Data Report NV-84-1, 247 p.

----1985 [1988], Water-resources data for Nevada, water year 1985: U.S. Geological Survey Water-Data Report NV-85-1, 255 p.

Pupacko, Alex, La Camera, R.J., Riek, M.M., and Wood, D.B., 1988, Water-resources data for Nevada, water year 1986: U.S. Geological Survey Water-Data Report NV-86-1, 263 p.

Pupacko, Alex, La Camera, R.J., Riek, M.M., and Swartwood, J.R., (in press), Water-resources data for Nevada, water year 1987: U.S. Geological Survey Water-Data Report NV-87-1. 


\section{National Atmospheric-Deposition Trends (Project 005)}

Location: Smith Valley in Lyon County.

Project Chief: Richard J. La Camera.

Period of Project: Continuous since 1985.

Cooperating Agencies: None (U.S. Geological Survey program).

Problem: Acid precipitation has caused adverse ecological and economic consequences in the eastern United States. In the western United States, the chemical composition and variability of wet atmospheric deposition is largely unknown due to a lack of quantitative data. However, industrial and vehicular emissions, which are known to cause acid precipitation in the east, are also found in the west.

Objectives: This study is part of a nationwide program to quantify the chemical properties of wet

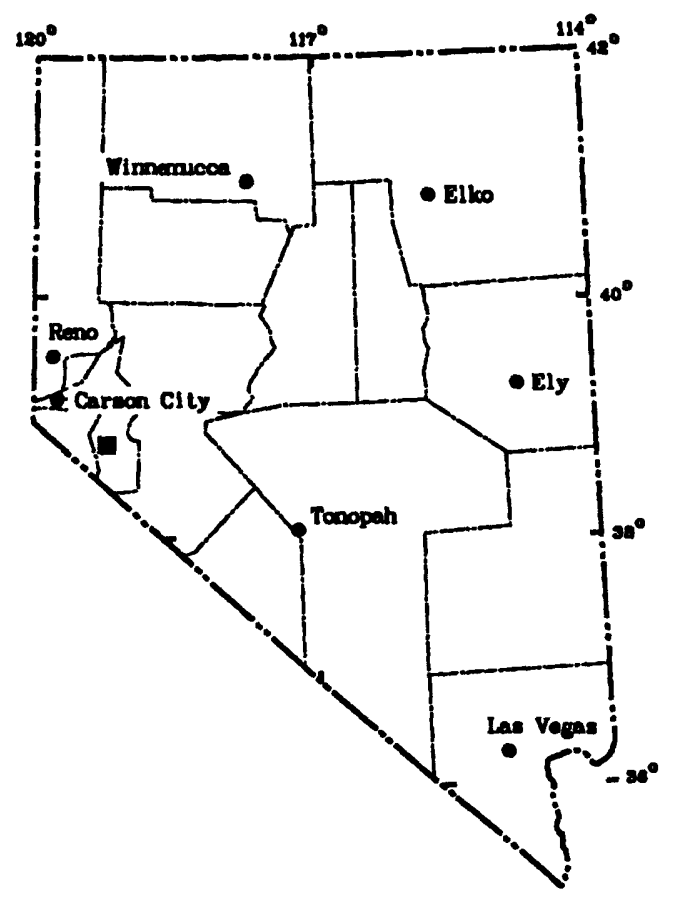
atmospheric deposition in the Nation. Currently, the study is focused on sampling and analyzing variations and trends with respect to time.

Approach: A single atmospheric-deposition sampler is being operated in Smith Valley, Nev. The sampler is checked weekly; however, measurements can be made only during those weeks when significant precipitation occurs. Samples are analyzed for $\mathrm{pH}$ and specific conductance.

Progress and Significant Results, Fiscal Years 1985-88: Sampling was continued on a weekly basis throughout the $1985-88$ period. During 1988, 20 samples that contained adequate quantities of precipitation for field analysis of $\mathrm{pH}$ and specific conductance were collected. No acidity was detected. Wet fall data was published in the annual data summaries of the National Atmospheric Deposition Program.

Plans for Fiscal Year 1989: The site will continue to be operated as it has in the past. There are no plans for any new sites at present. 


\section{Flood-Insurance Studies (Project 006)}

Location: Northem Nevada.

Project Chief: Rhea P. Williams, 1986-88;

Robert R. Squires, 1985.

Period of Project: 1985-89.

Cooperating Agencies: Federal Emergency

Management Agency and Federal Flood

Insurance Administration.

Problem: Flooding in arid regions can be unusually devastating. This is because most rain occurs in the spring, when rain on snow events are likely and sparse vegetation and compacted desert soils allow little infiltration. Excessive overland flow is also a random, but not uncommon, consequence of locally intense thunderstorms. The National Flood Insurance Act of 1968 provides that the Federal Emergency Management Association (FEMA) operate a flood

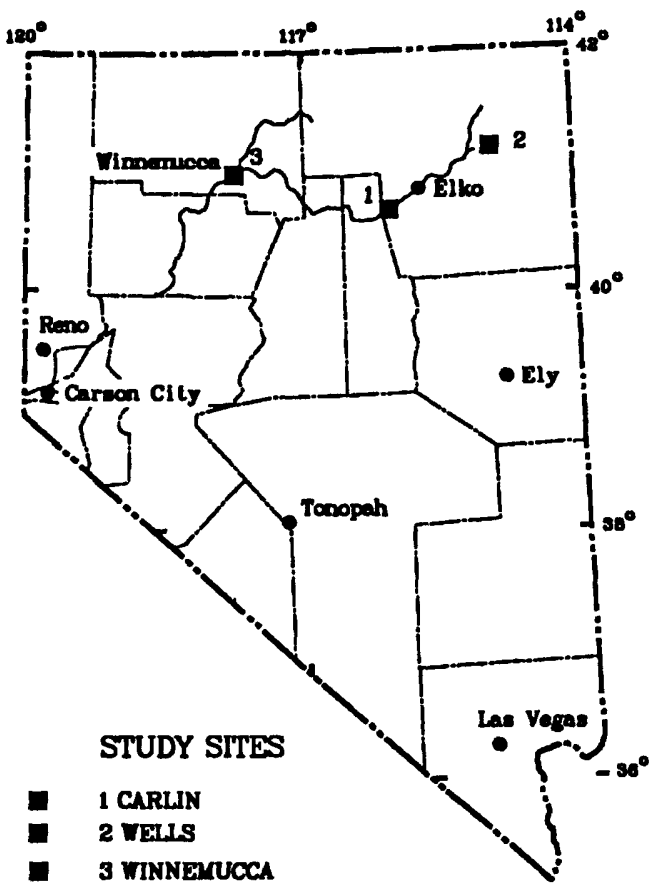
insurance program through the Federal Flood Insurance Administration. FEMA needs information from flood studies in selected areas to determine applicable flood insurance premiums.

Objectives: The objective of this study is to evaluate several methods and develop the most efficient procedures to attain the information and accuracy required by FEMA on flood-frequency and inundated areas. Estimates of flood frequency and the associated inundated area can be made a number of ways depending on the information available and the accuracy required. A method in use requires long-term measurement of river stages and discharge. Other methods require detailed analysis of river slope, channel and flood-plain dimensions, drainage networks, and runoff characteristics of the drainage basin.

Approach: Precipitation, river-stage, and discharge measurements are being collected as part of the surfacewater data network. Flood frequencies will be estimated from long-term measurements of river stages and discharge or from regional flood-frequency analyses. River slopes, channel and flood-plain dimensions, drainage networks, and runoff characteristics of drainage basins will be estimated from maps, where possible, and measured directly otherwise. Areas of potential inundation will be estimated using ground surveys, photogrammetry, and other available data in conjunction with flood-frequency estimates, hydraulic analysis, and, as appropriate, drainage-basin models.

Progress and Significant Results, Fiscal Years 1985-88: Flood-boundary data for the city of Winnemucca was compiled for FEMA. Analysis of data from the Wells flood study is almost finished.

Plans for Fiscal Year 1989: Compilation of the flood data for Wells will be completed and sent to FEMA. Studies in the Carlin area and Humboldt River Basin are planned for 1989. 


\section{Water Use in Nevada (Project 007)}

Location: Statewide.

Project Chief: E. James Crompton, 1988; Elizabeth A. Frick, 1985-87;

Period of Project: Intermittent since October 1978.

Cooperating Agency: Nevada Division of Water Resources.

Problem: Nevada is an arid state with limited water resources. Water-use data are critically needed for the planning and management of this resource. The U.S. Geological Survey is participating in a cooperative program with the Nevada Division of Water Resources (NDWR) to determine water use in basins designated as areas of critical water supply.

Objectives: The program provides water-use information for the optimum utilization and management of the State's water resources. It provides for the collection, storage, and dissemination of water-use data to complement the available water-quantity and water-quality information. The storage system is designed to handle site-specific and aggregated water-use data to meet the needs of local users, the U.S. Geological Survey, and other Federal agencies.

Approach: Information is to be compiled on the basis of the smallest unit feasible, usually individual points of diversion or withdrawal. Three major advantages of using this approach are: (1) more sources of reliable information are available at smaller scales; (2) compilations detailed enough to provide specific information about small areas are very much in demand at a local level; (3) larger scale requirements may be satisfied by summing the small-scale information.

Progress and Significant Results, Fiscal Years 1985-88: A poster display entitled "How Nevada Dealt its Water in 1985" was presented at the American Water Resources Association Water-Use Symposium. Several meetings were held with the Nevada State Engineer to discuss ways to increase the exchange of information between the two agencies.

Plans for Fiscal Year 1989: Development of a computerized storage and retrieval program for the State's water-level and crop-inventory data will continue. The 1987 National Water Summary, a USGS publication that includes water-use data throughout the United States, including Nevada, for 1985, will be published. A detailed report of Nevada water use in 1985 will be written. Expansion of the water-use program to include other State and regional agencies will be attempted.

Publications, Fiscal Years 1985-88:

Crompton, E.J., Frick, E.A., and Thiel, C.M., 1988, How Nevada dealt its water in 1985: American Water Resources Association Symposium on Water-Use Data for Water Resources Management, Tucson, Ariz., August 1988, Poster-Session Display.

Frick, E.A., and Carman, R.L., (in press), Nevada water supply and demand, in Moody, D.W., and Chase, E.B., compilers, National water summary 1987--Hydrologic events and water supply and demand: U.S. Geological Survey Water-Supply Paper 2350. 


\section{Flood Investigations of Nevada Streams (Project 036)}

Location: Statewide.

Project Chief: Rhea P. Williams, 1986-88;

Robert R. Squires, 1985.

Period of Project: Continuous since 1961.

Cooperating Agency: Nevada Department of Transportation.

Problem: The design of hydraulic structures within stream channels depends on accurate estimations of flood frequency and debris-flow magnitude. It is rarely possible to estimate flood-recurrence intervals based on channel characteristics alone; longterm measurements of peak flow are also necessary.

Objectives: Long-term peak-streamflow and debrisflow data for streams crossing Nevada highways will continue to be collected and analyzed for use by the Nevada Department of Transportation.

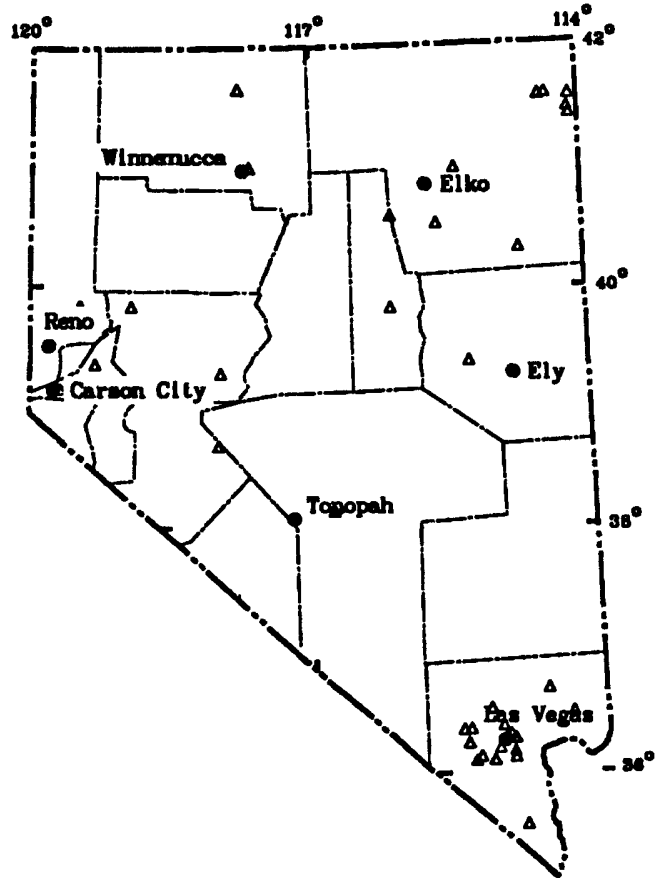

Approach: Crest-stage gages to measure peak streamflow stages have been installed, maintained, and operated. Periodic visits to the sites are made to verify flood recordings, maintain equipment, and make indirect measurements. Each crest-stage site will be monitored for at least 10 years to provide data showing flood magnitude and frequency. Debris flows will be visited as they occur and, where debris flows occur on streams not formerly monitored with crest-stage gages, the streams will be evaluated for their importance as possible year-round measurement sites.

Progress and Significant Results, Fiscal Years 1985-88: Peak-streamflow data were collected and interpreted at 45 sites in fiscal year 1986, 35 sites in fiscal year 1987, and 40 sites in fiscal year 1988. Each year, several additional sites which experienced severe flooding or debris flows were also investigated. All previously unpublished data for 1984-85 were submitted for publication in the 1987 water-data report. Statistical analyses were used to develop regional flood-frequency regression relations for streams monitored in this study.

Plans for Fiscal Year 1989: Peak-streamflow data collection and investigation of debris flows will continue. The regional flood-frequency report for Nevada streams will be completed. 
Publications, Fiscal Years 1985-88:

Frisbie, H.R., La Camera, R.J., Riek, M.M., and Wood, D.B., 1984, Water-resources data for Nevada, water year 1983: U.S. Geological Survey Water-Data Report NV-83-1, 328 p.

-----1985, Water-resources data for Nevada, water year 1984: U.S. Geological Survey Water-Data Report NV-84-1, $247 \mathrm{p}$.

-.---1985 [1988], Water-resources data for Nevada, water year 1985: U.S. Geological Survey Water-Data Report NV-85-1, 255 p.

Pupacko, Alex, La Camera, R.J., Riek, M.M., and Wood, D.B., 1988, Water-resources data for Nevada, water year 1986: U.S. Geological Survey Water-Data Report NV-86-1, 263 p.

Pupacko, Alex, La Camera, R.J., Riek, M.M., and Swartwood, J.R., (in press), Water-resources data for Nevada, water year 1987: U.S. Geological Survey Water-Data Report NV-87-1. 


\section{Pumping Effects on Devils Hole (Project 049)}

Location: Ash Meadows, Amargosa Desert, Nevada.

Project Chief: Craig Westenburg, 1987-88;

Daniel E. Hitch, 1986.

Period of Project: Continuous since 1970.

Cooperating Agencies: National Park Service.

Problem: Devils Hole is the sole habitat of the Devils Hole pupfish. Water levels in Devils Hole and nearby springs are significantly affected by wells pumping in Ash Meadows. Lowered water levels have a deleterious effect on Devils Hole pupfish by lessening the growth of algae on which the fish feed.

Objectives: Water levels in Devils Hole and discharge at nearby springs are being monitored to determine the effects of pumping in nearby wells.

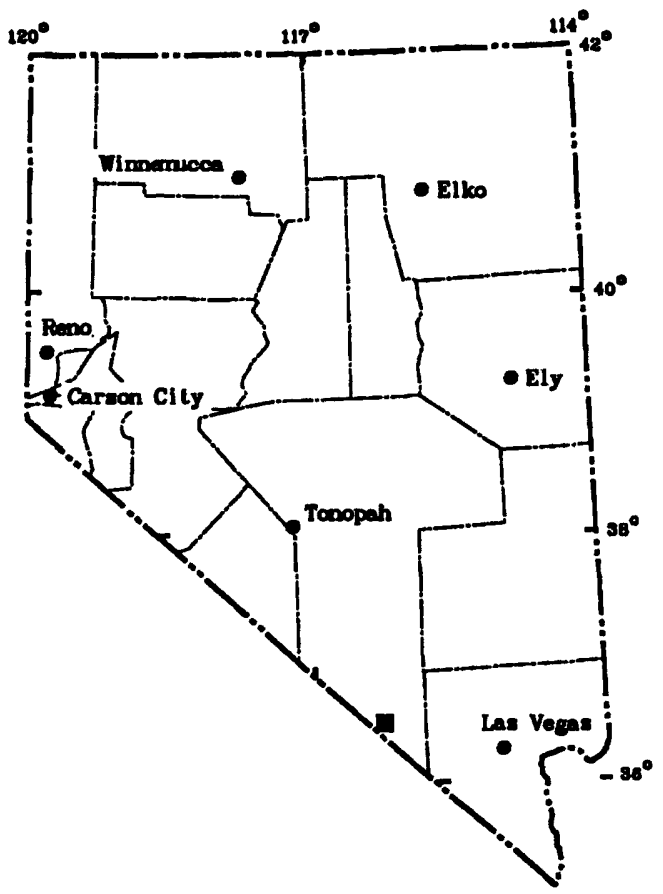

Approach: Measurements of water levels in Devils Hole and nearby wells, and discharge of springs and flowing wells, are being made on a monthly or more frequent basis.

Progress and Significant Results, Fiscal Years 1985-88: Monthly water-level and discharge measurements were collected from wells and springs throughout the study period. The data were entered into the NWIS computer data base.

Plans for Fiscal Year 1989: Routine data collection will be continued. A summary report of data collected during the 1978-88 water years will be prepared. 


\section{Environmental Hydrologic Studies (Project 056)}

Location: Carson City and Las Vegas areas.

Project Chief: Patrick A. Glancy, 1987-88;

Terry Katzer, 1985-86.

Period of Project: Continuous since 1973.

Cooperating Agency: Nevada Bureau of Mines and Geology.

Problem: Western Nevada has a striking contrast in landscape and geohydrologic conditions which result in a wide variety of fluvial hazards. Maps showing flood potential, water logging, and fluvial-debris hazards greatly assist planners, developers, and water users in dealing with expanding urban growth and consequent conflicting demands on water resources.

Objectives: A variety of fluvial hazards and aquifer characteristics are to be mapped at a scale

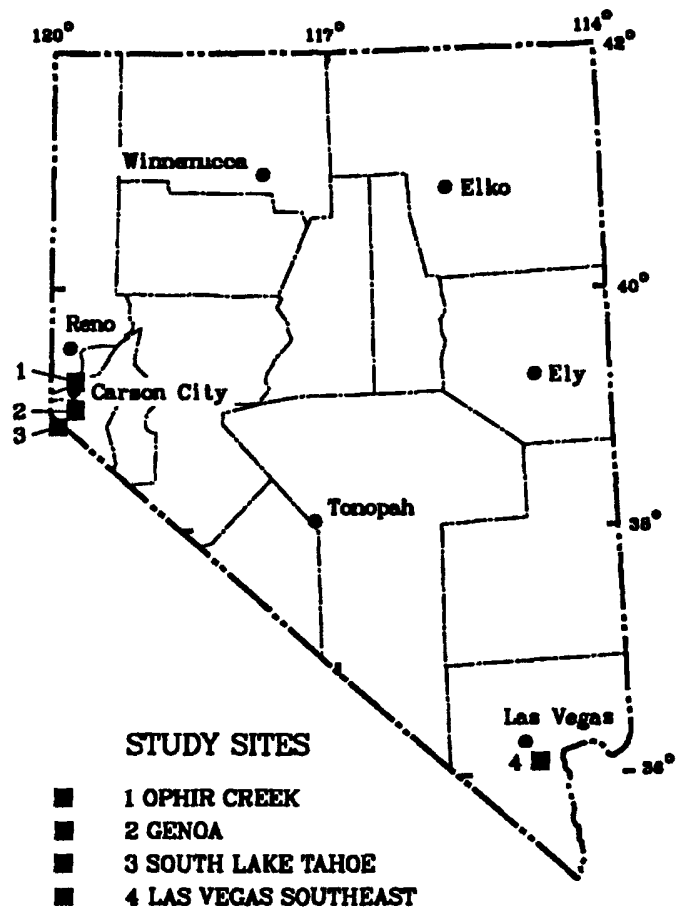
of 1:24,000. These include: (1) flood-hazard zones, including information on magnitude and recurrence interval; (2) debris-transport hazards; (3) areas of shallow ground water and water logging; and (4) wellyield information (transmissivity distribution).

Approach: Information is to be obtained from existing reports and from original field work. The field work involves mapping of flood-prone areas, evaluation of potential for hazardous debris movement down mountainstream channels into valley areas, and collection of data on water levels and well yields. The work began in Washoe Valley and later was extended to other areas of western and southern Nevada. The results are to be published on 7-1/2-minute quadrangle maps.

Progress and Significant Results, Fiscal Years 1985-88: The Vista Quadrangle environmental map was completed and is in press. A first draft of the report on the Ophir Creek flood of 1983 was completed. It was coauthored by John Bell of the Nevada Bureau of Mines and Geology who reviewed and made additions to the initial draft. A flood-and debris-hazard map of the Genoa 7-1/2-minute quadrangle was completed and placed in technical review. In 1988, part of the funding was reallocated to study radon gas accumulation in public and private buildings throughout the State.

Plans for Fiscal Year 1989: Technical review of the Genoa report will be completed and it will be prepared for publication. Sampling of wells in Carson City, Douglas, and Washoe Counties will be completed. 


\section{Publications, Fiscal Years 1985-88:}

Bell, J.W., and Katzer, Terry, 1984, Quaternary tectonic history of the IXI Canyon quadrangle, Dixie Valley, Nevada (abs.): Geological Society of America Abstracts with Programs, v. 16, no. 6, p. 442.

----1987, Surficial geology, hydrology, and late Quaternary tectonics of the IXI Canyon area, Nevada--As related to the 1954 Dixie Valley earthquake: Nevada Bureau of Mines and Geology Bulletin 102, 52 p.

Berggren, Gregg, and Harrill, J.R., 1986, Vegetation, South Lake Tahoe quadrangle [Nevada and Califomia]: Nevada Bureau of Mines and Geology Urban Maps Series, South Lake Tahoe Folio, Map 2Ae, scale 1:24,000.

-----1986, Vegetation, South Lake Tahoe quadrangle, Nevada and California: Nevada Bureau of Mines and Geology Open-File Report 86-3 [supplement to Urban Map 2Ae], 2 p.

Glancy, P.A., 1984, Flash flooding--A critical hydrologic process that relates man and geomorphology in western Nevada, in Lintz, Joseph, Jr., ed., Western geological excursions [in conjunction with 1984 annual meetings of Geological Society of America and affiliated societies]: University of Nevada, Reno, Mackay School of Mines, v. 3, p. 113-114.

----1985, The Ophir Creek debris flood of May 30, 1983--A real test of geohydrologic hazard mapping (abs.): Specialty Conference on Delineation of Landslide, Flash Flood, and Debris Flow Hazards in Utah, Logan Utah, June 1984, Proceedings, p. 195-196.

Glancy, P.A., and Whitney, J.W., 1986, Las Vegas Wash--Dynamic evolution of a southern Nevada drainage channel (abs.): Geological Society of America Abstracts with Programs, v. 18, no. 6, p. 615.

Harrill, J.R., 1986, Hydrology, South Lake Tahoe quadrangle, Nevada and California: Nevada Bureau of Mines and Geology Open-File Report 86-4 [supplement to Urban Map 2Af], 4 p.

Katzer, Terry, 1986, Ground water hydrology, Carson City quadrangle, Nevada: Nevada Bureau of Mines and Geology Open-File Report 86-7 [supplement to Urban Map 1Af], 7 p.

----1986, Flood and related debris flow hazards, Las Vegas SE quadrangle, Nevada: Nevada Bureau of Mines and Geology Open-File Report 86-5 [supplement to Urban Map 3A1], 4 p.

-----1986, Flood and related debris flow hazards, Las Vegas SW quadrangle [Nevada]: Nevada Bureau of Mines and Geology Urban Maps Series, Las Vegas SW Folio, Map 3Bl, scale 1:24,000.

Katzer, Terry, and Glancy, P.A., 1986, Flood and related debris flow hazards, South Lake Tahoe quadrangle, Nevada and California: Nevada Bureau of Mines and Geology Open-File Report 86-6 [supplement to Urban Map 2A1], 11 p.

Katzer, Terry, Harrill, J.R., Berggren, Gregg, and Plume, R.W., 1985, General ground-water map, Las Vegas SW quadrangle [Nevada]: Nevada Bureau of Mines and Geology Urban Maps Series, Las Vegas SW Folio, Map 3Bf, scale 1:24,000. 
Katzer, Terry, and Schroer, C.V., 1986, Flood and related debris-flow hazards along principal drainages, Carson City quadrangle, Nevada: Nevada Bureau of Mines and Geology Open-File Report 86-8 [supplement to Urban Map 1A1], 12 p.

Maurer, D.K., (in press), General hydrogeology of the Vista quadrangle [Nevada]: Nevada Bureau of Mines and Geology Urban Maps Series, Vista Folio, scale 1:24,000. 


\section{Beatty Disposal-Site Investigation (Project 072)}

Location: Amargosa Desert near Beatty, Nevada.

Project Chief: Brian J. Andraski, 1987-88;

Jeffrey M. Fischer, 1985-86.

Period of Project: Continuous since 1976.

Cooperating Agency: None (U.S. Geological Survey program).

Problem: Low-level, solid radioactive waste has been buried at a site near Beatty, Nev., from 1962 to the present. Knowledge of geology and hydrology at the site is inadequate. The net downward soilmoisture flux is unknown; consequently, the potential rate of downward movement of radioactive solutes cannot be determined for present climatic conditions.

Objectives: The potential transport rates and extent of downward migration of radionuclides within and

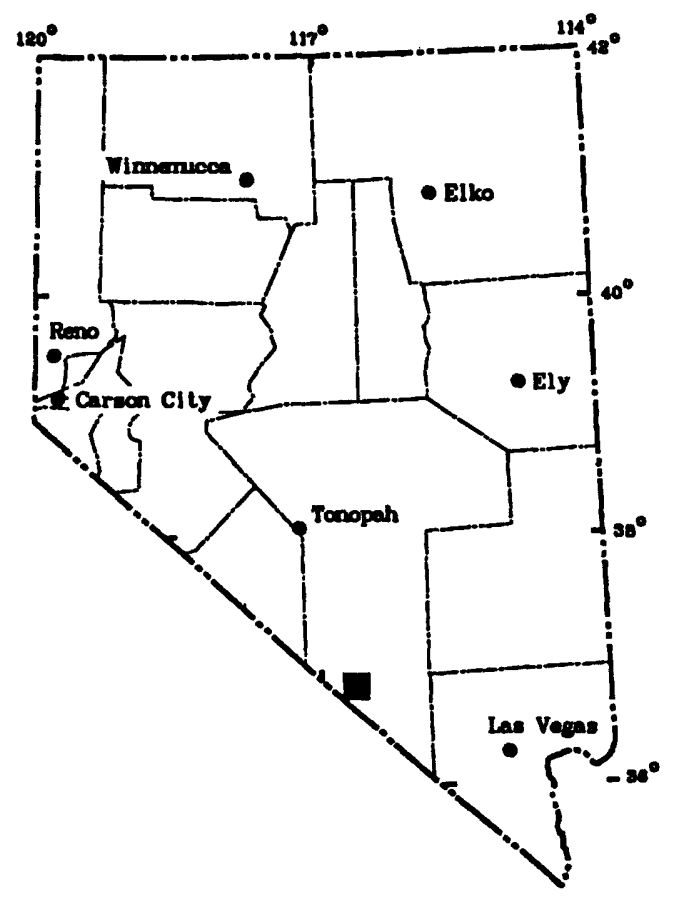
beneath the burial trenches will be estimated.

Analysis of how trench construction modifies the natural site environment will also be made. The results of these studies will be used to evaluate the geohydrologic suitability of the existing site and to contribute to the development of guidelines and criteria for selecting future burial sites.

Approach: Ground-water levels downgradient from the burial site and experimental trenches is being monitored. Water content and water potential (due to capillarity) are being measured in both the undisturbed soil and within experimental trenches. Other physical and chemical properties of the undisturbed profile and experimental trench backfill, such as structural stability and grain-size distribution, are also being characterized. The vertical variability of these properties is being evaluated through statistical analysis.

Progress and Significant Results, Fiscal Years 1985-88: Installation of psychrometers at the instrument shaft was completed in July 1987, and soil-water content, soil-water potential, and meteorologic parameters continue to be monitored at the shaft facility. A 400-foot-deep observation well was installed in February 1987 , and is being monitored. Two experimental trenches, designed to simulate burial of low-level radioactive waste, and to aid in evaluating the potential for radionuclide migration, were constructed in September 1987. Daily monitoring of 80 psychrometers (that measure water potential) and monthly monitoring of wells (with a neutron probe that determines water content) within and near the experimental trenches are being carried out. Subsidence and surface degradation of the experimental trenches are being monitored. Analyses of over 80 samples for soil-water content, bulk density, and coarse-fragment content indicate that trench construction greatly modifies the natural environment. 
Plans for Fiscal Year 1989: Soil-moisture instruments at the shaft facility and experimental trenches will continue to be monitored and instrument reliability will be evaluated. Meteorologic data will continue to be collected, and the weather station will be upgraded. Ground water from the observation well will be sampled and analyzed for major ions and radionuclides. Structural monitoring at the experimental trenches will continue. Laboratory analyses for particle-size distribution, saturated hydraulic conductivity, and water retention of the undisturbed soil and trench backfill will begin.

Publications, Fiscal Years 1985-88:

Andraski, B.J., (in press), Physical properties of trench backfill at a simulated burial site for low-level radioactive waste near Beatty, NV (abs.): 80th Annual Meeting, American Society of Agronomy, Anaheim, Calif., December 1988, Program of Agronomy Abstracts, v. 80.

Fischer, J.M., (in press), Hydrogeology of the near-surface unsaturated zone adjacent to the disposal site for low-level radioactive waste near Beatty, Nevada, in Bedinger, M.S., ed., Geologic aspects for siting and design of low-level radioactive waste isolation: U.S. Geological Survey Circular.

Fischer, J.M., and Nichols, W.D., 1986, Beatty, Nevada, in Dinwiddie, G.A., and Trask, N.J., eds., U.S. Geological Survey research in radioactive waste and disposal--Fiscal years 1983, 1984, 1985: U.S. Geological Survey Water-Resources Investigations Report 87-4009, p. 87-88.

Morgan, D.S., and Fischer, J.M., 1984, Unsaturated-zone instrumentation in coarse alluvial deposits of the Amargosa Desert near Beatty, Nevada: Sixth Annual Participants' Information Meeting--U.S. Department of Energy Low-Level Waste Management Program, Denver, Colo., September 1984, Proceedings, p. 617-630.

Nichols, W.D., 1987, Geohydrology of the unsaturated zone at the burial site for low-level radioactive waste near Beatty, Nye County, Nevada: U.S. Geological Survey Water-Supply Paper 2312, 57 p.

Prudic, D.E., and Dennehy, K.F., (in press), Summary of session 1--Hydrology of low-level radioactive-waste repository sites, in Bedinger, M.S., ed., Geologic aspects for siting and design of low-level radioactive waste isolation: U.S. Geological Survey Circular. 


\section{Regional Aquifer Study of the Great Basin (Project 091)}

Location: Nevada, western Utah, and parts of adjacent states.

Project Chief: James R. Harrill.

Period of Project: 1980-88.

Cooperating Agency: None (U.S. Geological Survey program).

Problem: The Great Basin contains an extensive regional ground-water system of about 200 valleyfill aquifers which, in some places, are underlain and interconnected by permeable, consolidated rock. This system has been included in a national program of regional aquifer-systems analysis (RASA). The

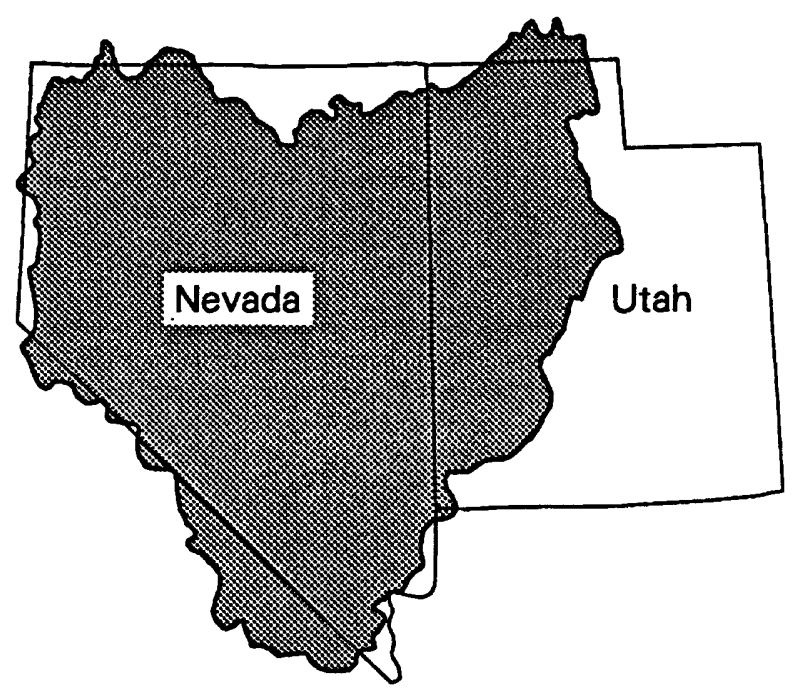

Great Basin area of Nevada and Utah is experiencing increasing demands for water. Demand in many areas has reached the point where careful management is needed to meet anticipated future needs. This study was needed to provide understanding of the system at a regional scale essential for wise management of the resource.

Objectives: The general objectives were to: (1) describe, both hydraulically and geochemically, the present ground-water system and the original ground-water system as it existed prior to development; (2) analyze the changes which led to the present condition of the system; (3) tie together, in a regional analysis, the results of prior studies dealing with individual segments of the system; and (4) provide predictive capabilities through which the effects of further ground-water development can be estimated.

Approach: The approach was to identify widespread hydrologic problems and areas typical of the Great Basin, to conduct detailed study, and then to regionalize results and incorporate them into an overall analysis of the Great Basin. Effort was concentrated in three general directions: (1) a description and regional analysis of aquifers; (2) a series of detailed studies to produce information that has transfer value to similar areas; and (3) to draw results together into a comprehensive regional analysis.

Progress and Significant Results, Fiscal Years 1985-88: All field work and analyses were completed. Reports were drafted and placed in review. A report on regional simulation was approved by the Director, USGS, and is in press. A draft of a report on regional geochemistry was completed and the manuscript sent out for colleague review. The total number of reports published to date for this regional assessment is 33 , including one of three chapters of Hydrologic Atlas 694. This atlas provides a description of the geologic framework, water levels, and flow systems of the study area.

Plans for Fiscal Year 1989: The remaining two chapters of the atlas will be published and other reports will be processed to approval. 


\section{Publications, Fiscal Years 1985-88:}

Bedinger, M.S., Harrill, J.R., Langer, W.H., Thomas, J.M., and Mulvihill, D.A., 1984, Maps showing groundwater levels, springs, and depth to ground water, Basin and Range province, Nevada: U.S. Geological Survey Water-Resources Investigations Report 83-4119-B, 2 sheets, scale 1:500,000.

Bedinger, M.S., Harrill, J.R., and Thomas, J.M., 1984, Maps showing ground-water units and withdrawals, Basin and Range province, Nevada: U.S. Geological Survey Water-Resources Investigations Report 83-4119-A, 2 sheets, scale 1:500,000.

Bunch, R.L., and Harrill, J.R., 1984, Compilation of selected hydrologic data from the MX missile-siting investigation, east-central Nevada and western Utah: U.S. Geological Survey Open-File Report 84-702, $123 \mathrm{p}$.

Burbey, T.J., and Prudic, D.E., 1985, Simulation of regional ground-water flow in carbonate-rock aquifers of the Great Basin in Nevada, Utah, and adjacent states (abs.): Geological Society of America Abstracts with Programs, v. 17, no. 7, p. 534.

-----(in press), Conceptual evaluation of regional ground-water flow in the carbonate-rock province of the Great Basin, Nevada, Utah, and adjacent states: U.S. Geological Survey Professional Paper 1409-D.

Carlton, S.M., 1985, Fish Springs multibasin flow system, Nevada and Utah: University of Nevada, Reno, Mackay School of Mines, unpublished M.S. thesis 1941, 103 p.

Carlton, S.M., and Thomas, J.M., 1986 [1987], Documentation for a digital computer model of the basin-fill aquifer in Smith Creek Valley, Lander County, Nevada: U.S. Geological Survey contribution; available only from National Technical Information Service, U.S. Department of Commerce, Springfield, VA 22161, accession number PB-87 142899 (text) and PB-87 142907 (magnetic tape).

Carman, R.L., 1985, Estimating evapotranspiration from a phreatophyte area in Smith Creek Valley, Nevada (abs.): 17th Conference, Agricultural and Forest Meteorology, and Seventh Conference, Biometeorology and Aerobiology, Scottsdale, Ariz., May 1985, Program, p. 48.

----(in press), Data on evapotranspiration in phreatophyte areas, Smith Creek Valley and Carson Desert, west-central Nevada, 1983: U.S. Geological Survey contribution; available only from National Technical Information Service, U.S. Department of Commerce, Springfield, VA 22161, accession numbers PB-89 167399 (text) and PB-89 167407 (magnetic tape).

Dettinger, M.D., (in press), Evaluation of ground-water resources in a structurally extended terrain-Geologic considerations in the eastern Great Basin, Nevada and Utah (abs.): American Geophysical Union, EOS, v. 69, no. 44.

Duffrin, B.G., Berger, D.L., and Schaefer, D.H., 1985, Principal facts for gravity stations in the Humboldt House geothermal area, Pershing County, Nevada: U.S. Geological Survey Open-File Report 85-162, $11 \mathrm{p}$.

Gates, J.S., 1984, Hydrogeology of northwestern Utah and adjacent parts of Idaho and Nevada: Utah Geological Association Publication 13, p. 239-248. 
Gates, J.S., 1987, Ground water in the Great Basin part of the Basin and Range province, western Utah: Utah Geological Association Publication 16, p. 75-89.

Harrill, J.R., 1986, Great Basin regional aquifer-system study, in Sun, R.J., ed., Regional aquifer-system analysis program of the U.S. Geological Survey--Summary of projects, 1978-84: U.S. Geological Survey Circular 1002, p. 146-151.

Harrill, J.R., Gates, J.S., and Thomas, J.M., (in press), Major ground-water flow systems in the Great Basin Region of Nevada, Utah, and adjacent states: U.S. Geological Survey Hydrologic Investigations Atlas HA-694-C.

Harrill, J.R., Welch, A.H., and Preissler, A.M., (in press), Hydrogeochemical evidence for subsurface inflow to Stagecoach Valley, Lyon County, Nevada, in Subitzky, Seymour, ed., Selected papers in the hydrologic sciences: U.S. Geological Survey Water-Supply Paper.

Plume, R.W., 1984, Use of aeromagnetic data to define some properties of a carbonate-rock aquifer in eastern Nevada (abs.): Geological Society of America Abstracts with Programs, v. 16, no. 6, p. 624.

----1985, Geologic features that control regional ground-water movement in the eastern Great Basin, Nevada and Utah (abs.): Geological Society of America Abstracts with Programs, v. 17, no. 7, p. 691.

-----(in press), Use of aeromagnetic data to define boundaries of a carbonate-rock aquifer in east-central Nevada, in Subitzky, Seymour, ed., Selected papers in the hydrologic sciences: U.S. Geological Survey Water-Supply Paper 2330.

Plume, R.W., and Carlton, S.M., (in press), Hydrogeology of the Great Basin region of Nevada, Utah, and adjacent states: U.S. Geological Survey Hydrologic Investigations Atlas HA-694-A, 1 sheet, scale $1: 1,000,000$.

Robbins, S.L., Prudic, D.E., Schaefer, D.H., and Clutsom, F.G., 1985, Principal facts and density estimates for borehole gravity stations in three water wells located in Dixie and Paradise Valleys, Nevada: U.S. Geological Survey Open-File Report 85-426, 20 p.

Schaefer, D.H., 1988, Bouguer-gravity anomaly maps of Paradise, Stagecoach, Dixie, Fairview, and Stingaree Valleys, northwestern Nevada: U.S. Geological Survey Geophysical Investigations Map GP-985, 1 sheet.

Schaefer, D.H., Duffrin, B.G., and Plume, R.W., 1986, Principal facts for gravity stations in Paradise and Stagecoach Valleys, Humboldt and Lyon Counties, Nevada: U.S. Geological Survey Open-File Report 85-694, 15 p.

Schaefer, D.H., Thomas, J.M., and Duffrin, B.G., 1984, Principal facts for gravity stations in Dixie, Fairview, and Stingaree Valleys, Churchill and Pershing Counties, Nevada: U.S. Geological Survey Open-File Report 84-586, 15 p.

Thomas, J.M., Carlton, S.M., and Hines, L.B., (in press), Ground-water hydrology and simulated effects of development in Smith Creek Valley, a hydrologically closed basin in Lander County, Nevada: U.S. Geological Survey Professional Paper 1409-E. 
Thomas, J.M., Mason, J.L., and Crabtree, J.D., 1986, Ground-water levels in the Great Basin region of Nevada, Utah, and adjacent states: U.S. Geological Survey Hydrologic Investigations Atlas HA-694-B, 2 sheets.

Thomas, J.M., Welch, A.H., and Preissler, A.M., 1985, Geochemical evolution of ground water in a hydrologically closed basin, northem Basin and Range province, Nevada (abs.): Practical Applications of Ground-Water Geochemistry Conference, Banff, Canada, June 1984, Proceedings, p. 189.

-.--(in press), Geochemical evolution of ground water in Smith Creek Valley, a hydrologically closed basin in central Nevada: Applied Geochemistry.

Welch, A.H. and Williams, R.P., 1986-87, Data on ground-water quality for $1^{\circ}$ by $2^{\circ}$ quadrangles [see list below]: U.S. Geological Survey Open-File Report 85-648, scale 1:250,000.

85-648A. Millet quadrangle (central Nevada), 1986.

85-648B. Elko quadrangle (eastern Nevada), 1986.

85-648C. Ely quadrangle (eastern Nevada), 1986.

85-648D. Lund quadrangle (eastern Nevada), 1986.

85-648E. McDermitt quadrangle (northern Nevada), 1987.

85-648F. Lovelock quadrangle (western Nevada), 1987.

85-648G. Winnemucca quadrangle (central Nevada), 1987.

85-648H. Reno quadrangle (western Nevada), 1987.

85-648I. Walker Lake quadrangle (western Nevada and eastern California), 1987.

85-648J. Tonopah quadrangle (central Nevada), 1987.

85-648K. Goldfield quadrangle (central Nevada), 1987.

85-648L. Caliente quadrangle (eastern Nevada), 1987.

85-648M. Death Valley quadrangle (southern Nevada), 1987.

85-648N. Kingman quadrangle (southern Nevada), 1987. 


\section{Carson Valley Ground-Water Model (Project 096)}

Location: Douglas County, Nevada, and Alpine County, California.

Project Chief: Douglas K. Maurer.

Period of Project: 1981-86.

Cooperating Agency: Douglas County.

Problem: Rapid growth in Carson Valley and surrounding areas is causing increased demand for development of the ground-water resources underlying the valley. A mathematical model of the ground-water reservoir and its relation with surface water in the basin will be useful in assessing the impact of ground-water development on these resources.

Objectives: A ground-water model of Carson Valley, based on investigation of the basin geology and hydrology, was prepared to simulate the response of the

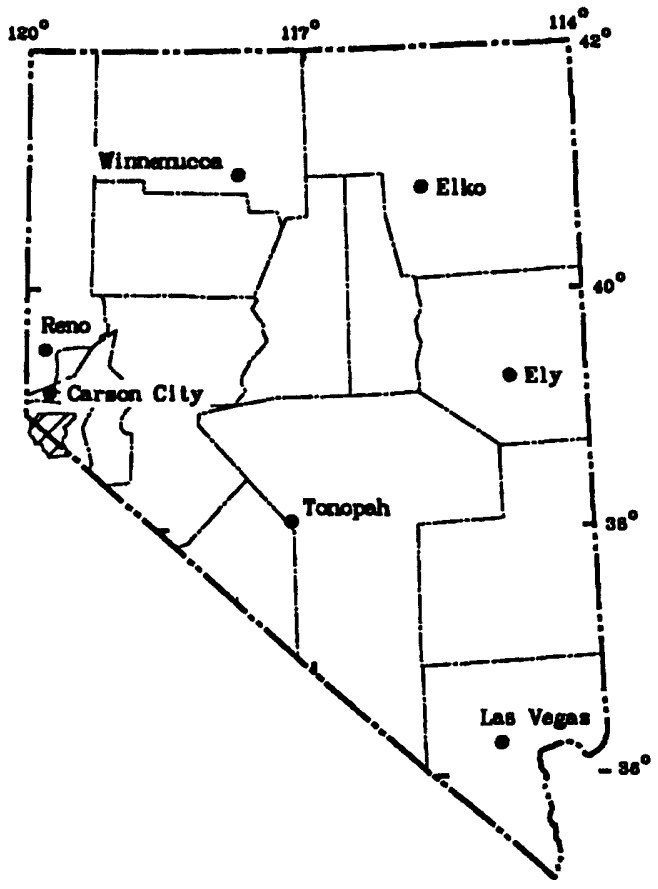
aquifer to changes in recharge and discharge.

The model was used to simulate the effects of various development scenarios suggested by the cooperator.

Approach: Gravity and seismic geophysical surveys provided data on the thickness and distribution of aquifers. Data on the characteristics of the aquifers were obtained from the U.S. Bureau of Reclamation, pump tests on existing wells, and studies of water-level fluctuations. Each element of ground-water recharge and discharge was quantified and used in the mathematical model. The model included a representation of the Carson River and simulated interaction between the surface- and ground-water systems.

Progress and Significant Results, Fiscal Years 1985-88: All phases of data collection, modeling, and the final project report were completed in 1986. Model calibration involved matching 3 years of ground-water fluctuations and Carson River outflow for the basin at quarterly intervals. Simulation of seven management scenarios for a 45-year period showed that stream losses maintain water levels in the basin-fill aquifer and are the source for 70 percent of the pumped ground water.

Publications, Fiscal Years 1985-88:

Maurer, D.K., 1985, Gravity survey and depth to bedrock in Carson Valley, Nevada-California: U.S. Geological Survey Water-Resources Investigations Report 84-4202, 20 p.

----1986, Geohydrology and simulated response to ground-water pumpage in Carson Valley, a river-dominated basin in Douglas, County, Nevada, and Alpine County, California: U.S. Geological Survey WaterResources Investigation Report 86-4328, 109 p.

---1988, Simulated changes in ground-water flow caused by hypothetical pumping in east Carson Valley, Douglas County, Nevada: U.S. Geological Survey Open-File Report 87-765, 6 p. 


\section{Flood and Debris Hazards at the Nevada Test Site (Project 105)}

Location: Yucca Mountain, Nevada Test Site, Nye County, Nevada.

Project Chief: Patrick A. Glancy.

Period of Project: Continuous since 1981.

Cooperating Agency: U.S. Department of Energy.

Problem: Yucca Mountain is being considered as a storage site for high-level nuclear waste. Flooding and associated sediment movement is a continual natural hazard at Yucca Mountain and at the Nevada Test Site (NTS). Engineering designs for all types of waste-storage facilities, including critically sensitive ones, require that the hazards be defined. Current flood-prediction capability is inhibited by an inadequate understanding of the natural processes involved, shortages of necessary hydrologic data, and inadequate technology to interpret the data. Other

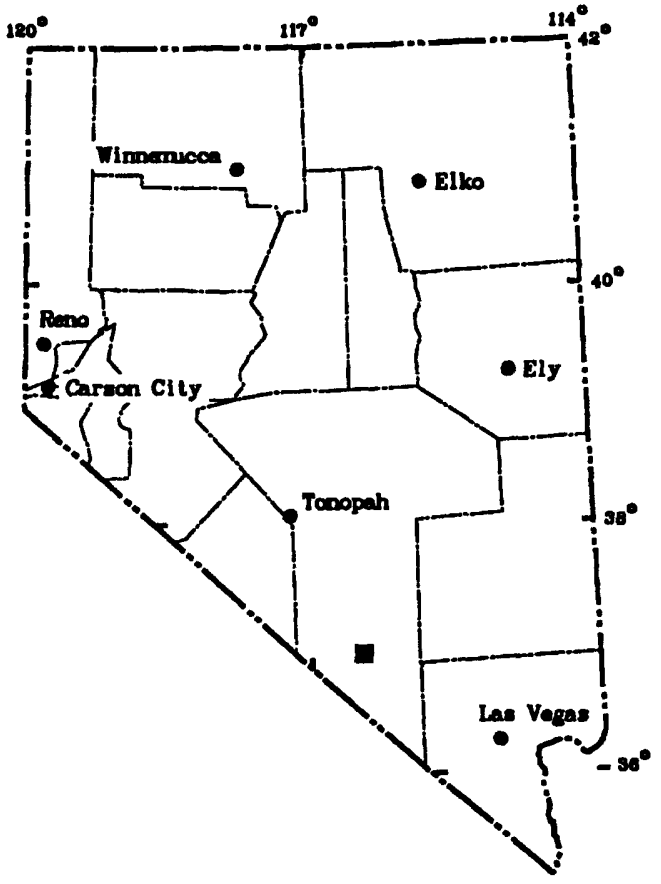
hydrologic studies for feasibility of nuclear wastestorage require runoff data, principally to determine effects of runoff on ground-water recharge.

Objectives: This study is intended to increase knowledge and understanding of flood processes throughout the Yucca Mountain area, NTS, and the surrounding region by: (1) adding needed hydrologic data on precipitation and runoff to the data base to enhance predictive capability; (2) expanding the data base of high-flow events; and (3) collecting information on prehistoric floods. The data are intended to be of use to other hydrologic studies as well.

Approach: A two-pronged approach that will improve the data base is planned: (1) An ongoing hydrologic data-collection program to investigate storm and runoff events will be the main focus of the study; this will include collection of precipitation and streamflow data, mainly at stream-gage sites. (2) Paleohydrologic data-collection and interpretation techniques developed by other investigators will be applied to determine those that are workable, and new techniques will be devised as necessary. These two approaches should lead to improved knowledge of the natural runoff processes, leading to the improved capability to predict flooding and severe debris transport by runoff.

Progress and Significant Results, Fiscal Years 1985-88: The streamflow and precipitation-measurement network operated on schedule, but only minor runoff occurred at a couple of sites in 1987-88. Stop-work orders by the Department of Energy (DOE) in 1987 and 1988 curtailed other field investigations. The revised site-characterization report for Yucca Mountain was nearly completed. A draft report on the evidence of prehistoric flooding and the potential for future flooding at Coyote Wash, Yucca Mountain, was approved by DOE and forwarded for USGS approval. Study plans and quality-assurance procedures were written and revised and an audit for quality assurance by DOE was successfully completed. 
Plans for Fiscal Year 1989: Streamflow data will continue to be collected and the streamflow-measurement network will be upgraded. Plans for the meteorology program will continue and be modified as necessary. The scientific investigation plan will be revised and completed. The prototype phase of the Yucca Mountain intensive-runoff study will be started, and a strategy for the paleohydrology study will be developed. 


\section{Remote Sensing in Hydrology (Project 109)}

Location: Statewide.

Project Chief: J. LaRue Smith.

Period of Project: Continuous since 1981.

Cooperating Agency: Mackay School of Mines, University of Nevada, Reno.

Problem: Nevada is the driest state in the Nation, averaging less than 10 inches per year of precipitation. The demand for water by the rapidly expanding population frequently exceeds the available supply. Agricultural practices account for over 90 percent of the total consumptive water use in Nevada. As the demand for potable and irrigation waters increase, the need for comprehensive planning and management tools becomes critical to sound management of State water resources.

Objectives: Digital remote-sensing techniques that can be used in obtaining water-resources data on a regular and reliable basis will be developed and implemented. Published methods will be used when applicable, and new methods will be developed and applied when appropriate.

Approach: A State water-data analysis system using standard remote-sensing methods will be developed to provide information that will aid in facilitating water-management policy. The proposed data-analysis system will provide the means to: (1) monitor and inventory land use in Nevada as related to water resources; (2) map regions of agriculture and phreatophytic plant growth where intense transpiration occurs; (3) map structural features for use in well-siting studies; (4) integrate remote-sensing and GIS data bases; and (5) offer the required flexibility to respond to present and future needs for water resources information.

Progress and Significant Results, Fiscal Years 1985-88: Remotely sensed data have been processed and printed by U.S. Geological Survey personnel in Flagstaff, Ariz., for a number of Nevada District projects. Landsat Thematic Mapper images were used to delineate the extent of high water in the Stillwater Wildlife Management Area of central Nevada during 1984 flooding. Linear geologic features and paleo-spring mounds in southern Nevada were identified for the Nevada Carbonate Aquifer Programs. A new image-analysis system has been acquired to more efficiently analyze radar data.

Plans for Fiscal Year 1989: Landsat Multispectral Scanner data will be used for the identification of phreatophyte zones in the Smoke Creek Desert area of western Nevada. Data from Landsat thematic mapper and advanced very high resolution radiometer sources will be investigated for use in determining evapotranspiration in Smith Creek Valley in central Nevada.

\section{Publication, Fiscal Years 1985-88:}

McBeth, P.E., Jr., 1986, Hydrogeologic significance of LANDSAT Thematic Mapper lineament analyses in the Great Basin: University of Nevada, Reno, unpublished M.S. thesis, 133 p. 


\section{Truckee River Water-Quality Model (Project 111)}

Location: Washoe and Storey Counties, Nevada.

Project Chief: Jon O. Nowlin.

Period of Project: 1982-87.

Cooperating Agencies: City of Reno and City of Sparks.

Problem: Rapid population growth in the Reno area has required expansion of the Reno-Sparks sewagetreatment plant. The plant discharges secondarytreated effluent to the Truckee River. Small agricultural diversions also exist along much of the Truckee River below Reno, reducing river flows during low-flow periods and contributing nonpoint loadings from return flow. Adverse water quality may affect the threatened Lahontan cutthroat trout and endangered Cui-ui Lakesuckers that spawn in the lower Truckee River and live in the receiving waters of

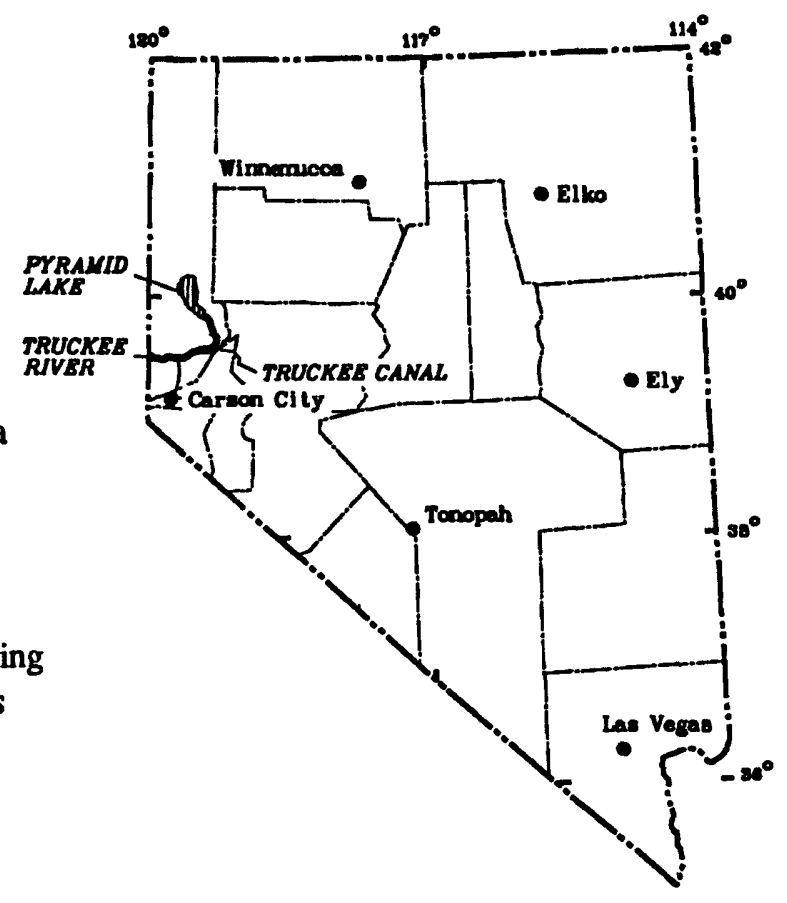
Pyramid Lake. Nutrient loadings from sewage effluent may also affect beneficial uses of Lahontan Reservoir, which receives diversions from the Truckee River.

Objectives: Evaluate potential impacts of increased sewage discharge, the effects of agricultural diversions, and the importance of agricultural return flows on instream quality of the Truckee River and Truckee Canal, and predict loads of constituents delivered to Pyramid Lake and Lahontan Reservoir. A waterquality model was developed to provide information on the sources, rates of transport, rates of consumption or adsorption, and net discharge of dissolved constituents in the Truckee River and Truckee Canal. It was also applied to evaluate potential effects on stream quality from alternative processes for sewage treatment, ranging from continued secondary treatment to tertiary treatment with denitrification of the effluent.

Approach: Selected water-quality indicators were modeled along a 56-mile reach of the Truckee River and along a 31-mile length of the Truckee Canal between the Reno-Sparks area and their respective discharge points in Pyramid Lake and Lahontan Reservoir. Four intensive stream-sampling studies had been made as part of another project in June and August of 1979 and 1980 to measure instream concentrations of dissolved oxygen, dissolved solids, biochemical oxygen demand, and nutrients (nitrogen and phosphorus). Other field studies included dye-tracer injection to determine river traveltimes for a wide range of flows and gas-tracer studies to develop methods for prediction of instream-reaeration coefficients. The results of the comprehensive field studies were used to calibrate and verify the model. Steady-state flows were modeled for conditions during spring-runoff high flow (June) and late-summer low flow (August). 
Progress and Significant Results, Fiscal Years 1985-87: The model was completed and reports published. Field studies showed that oxygen concentrations in the river and canal generally meet State standards except in heavily vegetated reaches during low flow at night. The calibrated and verified model simulates mean daily concentrations of dissolved solids; carbonaceous biochemical oxygen demand; organic-, ammonia-, nitrite-, and nitrate-nitrogen; ortho-, and total phosphorus; and dissolved oxygen. It also showed that river quality above Derby Dam is greatly influenced by combined urban and agricultural discharges from Steamboat Creek and North Truckee Drain, and that below Derby Dam the effects of nonpoint agricultural returns and ground-water inflows predominate. Simulations for low-flow conditions projected that waterquality standards for dissolved solids, nutrients, and minimum daily dissolved oxygen would not be met in one or more reaches of the river for all modeled alternatives at the proposed municipal sewage-discharge rate for the year 2000 .

\section{Publications, Fiscal Years 1985-87:}

Blodgett, J.C., Oltmann, R.N., and Poeschel, K.R., 1984, Estimation of streamflow for selected sites on the Carson and Truckee Rivers in California and Nevada, 1944-80: U.S. Geological Survey Water-Resources Investigations Report 84-4058, $223 \mathrm{p}$.

Brown, W.M. III, Nowlin, J.O., Smith, L.H., and Flint, M.R., 1986, River-quality assessment of the Truckee and Carson River system, California and Nevada--Hydrologic characteristics: U.S. Geological Survey Open-File Report 84-576, 201 p.

La Camera, R.J., Hoffman, R.J., Nowlin, J.O., Smith, L.H., and Lima, S.M., 1985, Data on surface-water quality and quantity, Truckee River system, Nevada and California, 1979-81: U.S. Geological Survey Open-File Report 84-238, 189 p.

Nowlin, J.O., 1987, Modeling nutrient and dissolved-oxygen transport in the Truckee River and Truckee Canal downstream from Reno, Nevada: U.S. Geological Survey Water-Resources Investigations Report 87-4037, $512 \mathrm{p}$.

-.--1987, Documentation for a digital computer model of nutrient and dissolved-oxygen transport in the Truckee River and Truckee Canal downstream from Reno, Nevada: U.S. Geological Survey Open-File Report 87-554, 181 p. 


\section{Dendrohydrology (Project 112)}

Location: Northeastern Nevada.

Project Chief: William D. Nichols.

Period of Project: 1982-85.

Cooperating Agencies: University of Arizona, University of Nevada, and Nevada Department of Conservation and Natural Resources.

Problem: Historic precipitation and streamflow records in the Great Basin are too short for meaningful statistical analysis of long-term hydrologic trends. Studies have shown that growth rings of trees can be correlated with both annual precipitation and mean annual stream discharge; this type of scientific investigation is termed "dendrohydrology." Tree-ring chronologies can be developed for periods 400-1,000 years before the present, thereby providing significantly long time series for hydrologic and climatic analysis.

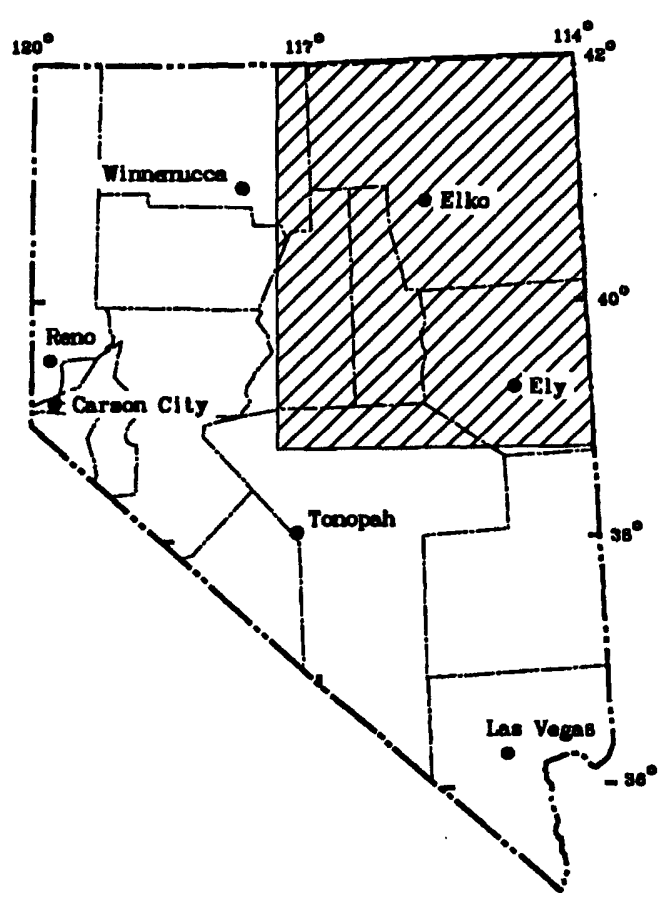

Objectives: Tree-ring chronologies for high- and low-altitude sites in the Nevada part of the Great Basin were developed. This information was then used to establish the appropriate transfer functions to correlate tree-ring width with measured values of precipitation and streamflow.

Approach: Cores were collected from trees growing in climatically sensitive conditions. Chronologies based on the width of tree rings were used to reconstruct prehistoric annual precipitation and runoff fluctuations through the use of transfer functions. The reconstructed hydrologic time series was then subjected to further statistical analysis.

Progress and Significant Results, Fiscal Years 1985-88: The project was completed in 1985. Chronologies were developed for 11 sites in northeastern Nevada. Precipitation and drought history reconstructions were made for the period 1600 to 1982.

Plans for Fiscal Year 1989: The project was completed and reports written. One report is awaiting publication.

\section{Publications, Fiscal Years 1985-88:}

Nichols, W.D., 1988, Drought duration and frequency in the north-central Great Basin, 1600-1982, and implications for water supply: Symposium on Water-Use Data for Water-Resources Management, American Water Resources Association, Tucson, Ariz., August 1988, p. 479-485.

Smith, W.P., 1986, Reconstruction of precipitation in northeastern Nevada using tree rings, 1600-1982: Journal of Climate and Applied Meteorology, v. 25, no. 9, p. 1255-1263. 


\section{Eastern Nevada Hydrology (Project 114)}

Location: Eastern Nevada.

Project Chief: Alex Pupacko, 1986-88;

Michael D. Dettinger, 1985.

Period of Project: 1982-87.

Cooperating Agency: Nevada Division of Water Resources.

Problem: Thick sequences of Paleozoic limestone and dolomite underlie much of eastern Nevada. These rocks comprise a deep carbonate-aquifer system of regional significance. Few data have been available to document the configuration, or even existence, of a regional flow system in the carbonate-rock province. Comprehensive studies of this aquifer system have not been made, and little appropriate data are available. Much new data must be collected

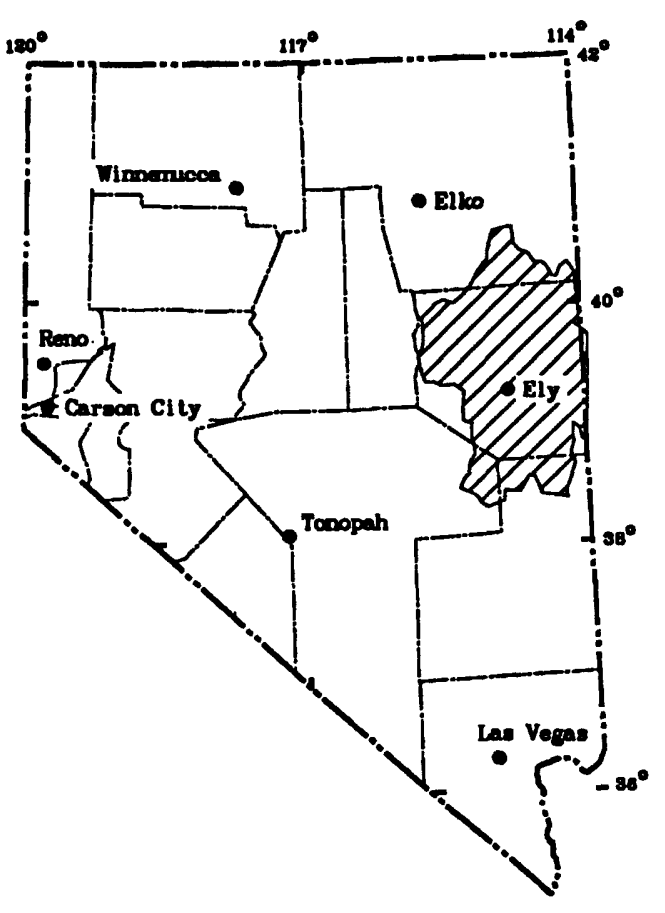
and existing data networks need to be expanded to define the system adequately. Some of the essential data can be obtained only by drilling deep test wells.

Objectives: The objectives of this study are to: (1) obtain and organize available data for the eastern Nevada carbonate-aquifer system; (2) establish new and expand existing hydrologic-data networks as needed for comprehensive planning, and develop working hypotheses as to how the system functions; and (3) develop a detailed program for a long-term (5-7 year) study of the carbonate-aquifer system that will test the hypotheses developed in this study.

Approach: During the first year, networks for the collection of surface-water, ground-water, water-quality, and precipitation data were established or expanded in eastern Nevada. During the second year, working hypotheses of how the system functions were developed, and a comprehensive plan for the further investigation of the eastern Nevada carbonate-aquifer system was prepared. During subsequent years, data collection was continued and a ground-water flow model of steady-state flow in Steptoe Valley was developed and tested.

Progress and Significant Results, Fiscal Years 1985-88: The project has significantly increased the available hydrologic data base in eastern Nevada. In 1985, a report describing a 10-year program for studying the carbonate aquifer was completed and published by the U.S. Department of the Interior. A flowmodeling study of ground-water flow in valley-fill deposits in Steptoe Valley was also completed. Installation of data-collection networks was completed in 1986.

Plans for Fiscal Year 1989: The active phase of the project is complete. Some data-collection elements have been continued or expanded under the carbonate-aquifer study (Project 128). A summary open-file report will be published documenting hydrologic data collected during 1982-87. 


\section{Publications, Fiscal Years 1985-88:}

Frick, E.A., 1985, Quantitative analysis of groundwater flow in valley-fill deposits in Steptoe Valley, Nevada: University of Nevada, Reno, unpublished M.S. thesis, $192 \mathrm{p}$.

Plume, R.W., 1988, Geologic features that affect the movement of recharge to ground-water basins adjacent to the central Egan Range, White Pine County, Nevada (abs.): Geological Society of America Abstracts with Programs, v. 20, no. 3, p. 221.

Savard, C.S., (in press), Hydrology of four watersheds in the carbonate-rock province, White Pine County, Nevada (abs.): 24th Annual American Water Resources Association Conference, Milwaukee, Wis., November 1988, Program.

U.S. Department of the Interior, 1985, A proposed program to study the water resources of the carbonate-rock system of eastern and southern Nevada: U.S. Department of the Interior, $14 \mathrm{p}$. 


\section{Vicee Canyon Recharge (Project 116)}

Location: Eagle Valley, Nevada.

Project Chief: Douglas K. Maurer.

Period of Project: 1983-88.

\section{Cooperating Agency: Carson City Public Works} Department:

Problem: Rapidly declining ground-water levels in the Eagle Valley area have prompted the search for additional water supplies, including ground-water recharge by augmented streamflow to Vicee Canyon, a tributary to the basin. The amount of the augmented streamflow that would actually recharge the groundwater system, and the amount that may be lost to evaporation, was unknown.

Objectives: Knowledge of the magnitude and efficiency of ground-water recharge from the

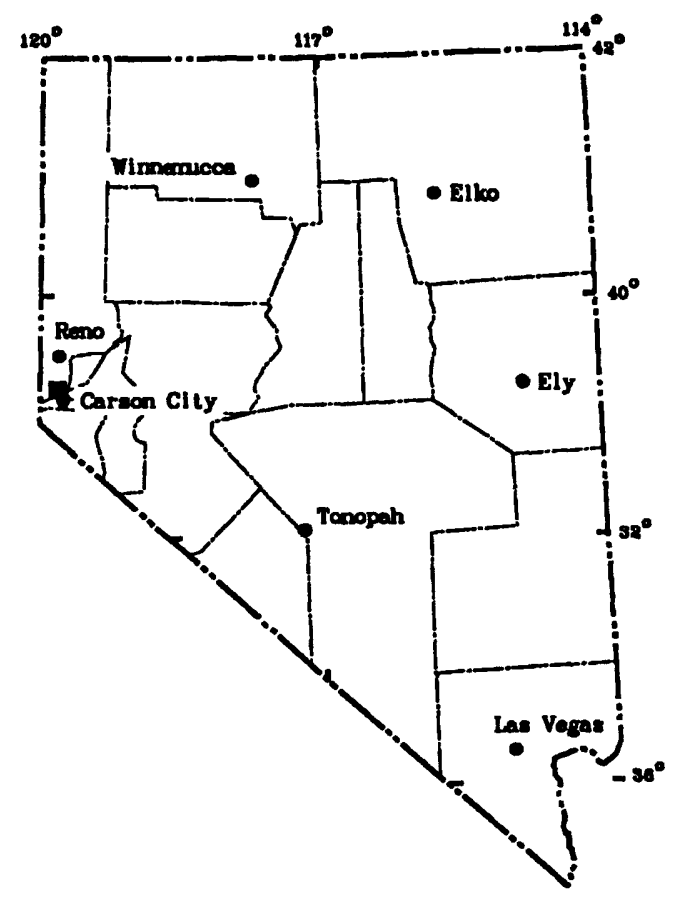
augmented streamflow is the main objective.

A secondary objective is to determine the impact of continuous discharge in an ephemeral channel on channel geometry, sediment load, and alluvial-fan morphology.

Approach: A definition of the effects of sustained streamflow from Vicee Canyon requires monitoring of streamflow at several points, monitoring changes in soil moisture and water-level fluctuations over the area where infiltration was expected to occur, and periodic surveys of longitudinal profiles of the stream channel and alluvial-fan surface.

Progress and Significant Results, Fiscal Years 1985-88: The study showed that long-term augmentation would erode the naturally occurring gravel infiltration bed. A simple model of the study area showed that water-levels could rise as much as 15-30 feet in the vicinity of a hypothetical 100-by-100-foot infiltration bed if streamflow were augmented with additional continuous flow of 1 cubic foot per second during a 5-year period.

Publications, Fiscal Years 1985-88:

Fischer, J.M., 1988, Streamflow infiltration and ground-water recharge through the unsaturated zone at Vicee Canyon, Nevada: University of Nevada, Reno, unpublished M.S. thesis, 100 p.

Maurer, D.K., and Fischer, J.M., (in press), Recharge to the Eagle Valley ground-water basin by streamflow in Vicee Canyon, west-central Nevada: U.S. Geological Survey Water-Resources Investigations Report 88-4158.

Maurer, D.K., and Myers, C.M., (in press), Recharging the ground water in Eagle Valley, west-central Nevada, by augmenting natural streamflow in Vicee Canyon: U.S. Geological Survey Open-File Report 88-487 (Water Fact Sheet). 


\section{Evolution of Nevada Water Law (Project 118)}

Location: Statewide.

Project Chief: Hugh A. Shamberger, 1985-88.

Period of Project: 1982-88.

Cooperating Agency: Nevada Division of Water Resources.

Problem: Nevada has one of the fastest growing populations of any state in the Nation. This growth has accelerated stresses on the State water resources. Conflicts over water rights have been common throughout Nevada's history, but because of the historically sparse population, most early conflicts were resolved by easily developed surface-water rights. The rapidly accelerating demand for ground water has caused, and will continue to cause, water-resource conflicts including those dealing with conjunctive use of surface and ground water.

Objectives: All available and pertinent knowledge of the development and evolution of Nevada water laws from 1866 to about 1960 will be documented and published.

Approach: Published and publicly available documents, as well as numerous persons who were or still are the principal activists in Nevada water law development, will be consulted during this project. A report of the findings will be published when the topic has been thoroughly researched.

Progress and Significant Results, Fiscal Years 1985-88: The lengthy report was drafted in 1986, and is currently undergoing review.

Plans for Fiscal Year 1989: Reviews will be completed and the report prepared for publication. 


\section{Streamflow-Network Evaluation (Project 119)}

Location: Statewide.

Project Chief: Freddy E. Arteaga.

Period of Project: 1983-85.

Cooperating Agencies: None (U.S. Geological Survey program).

Problem: Stream gaging in Nevada was begun in 1890 and has remained one of the most important aspects of basic water-resources data collection to this day. Several methods of direct and indirect measurement have been and continue to be used successfully in this endeavor, each with its own attendant accuracy and cost limitations. Costs for stream-gaging activities in the Nevada District accounted for approximately 20 percent of the budget in 1983. The continued importance of stream gaging on the national level requires that the most accurate and cost-effective methods of data collection be identified and promoted.

Objectives: The objective of this study was to associate the average standard error of each data-collection method currently in use with its inherent cost in order to determine the most productive cost-benefit ratio, with analysis of a variety of equipment, methods, sites, and budget levels.

Approach: The study analyzed the cost-effectiveness of a variety of streamflow-gaging methods for 81 sites that were under direct operation by Nevada District personnel in 1983. The possibility of developing streamflow data at ungaged sites was evaluated using flow-routing and statistical techniques. Cost-effective allocations of resources, including budget and operational criteria, were studied using statistical procedures (Kalman-filtering technique).

Progress and Significant Results, Fiscal Year 1985: The study showed that the methods used in Nevada produce acceptable data quality at a reasonable cost for the 81-site network in operation in 1983, and no reduction of gaging sites was recommended. Neither flow-routing nor statistical techniques provided sufficiently accurate results to warrant their use as substitutes for conventional stream gaging. An approximately 4-percent reduction in operational costs could be realized by redistributing expenditures more equitably between sites. The study also showed that a major source of error was periods of missing record, mostly due to equipment failure. The project ended in fiscal year 1985 and a report summarizing the findings was subsequently completed.

Plans for Fiscal Year 1989: The report will be prepared for publication.

Publication, Fiscal Years 1985-88:

Arteaga, F.E., (in press), Cost effectiveness of the stream-gaging program in Nevada: U.S. Geological Survey Water-Resources Investigations Report 87-4213. 


\section{Elko Geophysical Reconnaissance (Project 120)}

Location: Elko County, Nevada.

Project Chief: Donald H. Schaefer.

Period of Project: $1983-86$.

Cooperating Agency: U.S. Bureau of Land Management.

Problem: Many wells in the Elko area yield lowtemperature geothermal water. The area supports a population of approximately 8,000 people, a significant percentage of which could possibly use the geothermal resources for space heating. The U.S. Bureau of Land Management needed information on the probable extent and location of the resource to assist local residents in using the geothermal potential.

Objectives: Depth to bedrock in valley-fill sediments and the location and extent of the

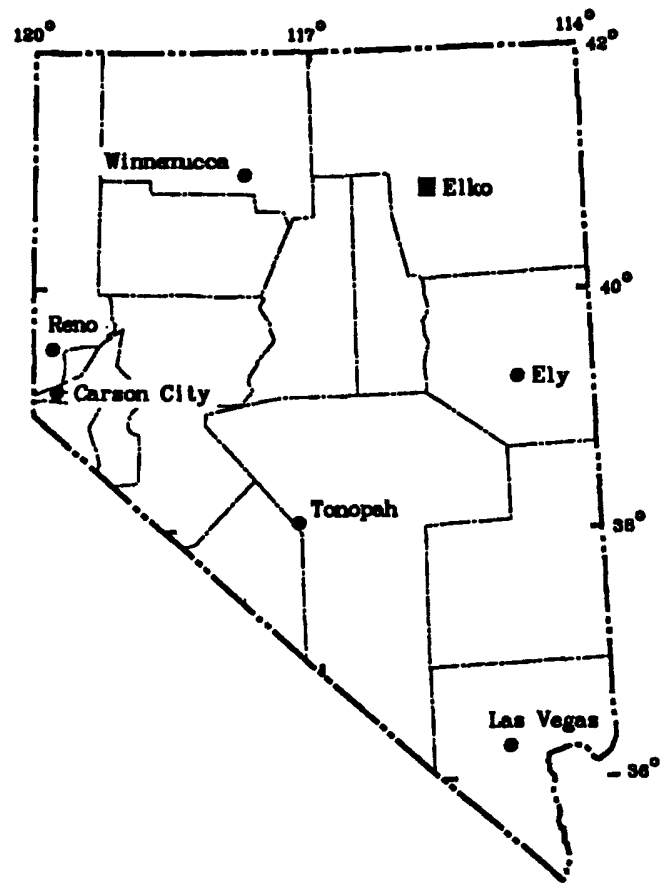
geothermal system near Elko were to be estimated through geophysical methods.

Approach: A detailed gravity survey, with stations located about 2,000 feet apart, was made, with effort concentrated to the north and northwest of town. Fifty regional stations were also used to measure regional gravity trends in the area. Gravity data were analyzed by standard methods, and depth to bedrock estimated and checked against measured values wherever possible. Limited seismic refraction, reflection, and electrical resistivity surveys were also made. Approximately 100 control points were used in the temperature survey.

Progress and Significant Results, Fiscal Years 1985-88: Depth-to-bedrock estimates were made from about 200 gravity measurements. The maximum thickness of valley-fill sediments (about 4,500 feet) was found to be west of Elko, and the average thickness of sediments in the remainder of the valley was 2,500 feet. Soiltemperature measurements, made at a depth of 6.6 feet at 35 locations in the study area, indicate a major thermal anomaly southwest of Elko, an area of known hot-springs activity. The project report was approved and submitted for publication.

\section{Publication, Fiscal Years 1985-88:}

Schaefer, D.H., (in press), Gravity, depth to consolidated rock, and soil temperature in the Elko area, northeastern Nevada: U.S. Geological Survey Miscellaneous Investigations Map I-1900. 


\section{Arsenic in the Western United States (Project 123)}

Location: Western United States.

Project Chief: Alan H. Welch.

Period of Project: 1983-87.

Cooperating Agencies: None (U.S. Geological Survey program).

Problem: Elevated concentrations of arsenic are not uncommon in ground water in the western United States. The geochemical processes responsible for the mobilization and removal of aqueous arsenic are poorly understood. This lack of knowledge limits the ability to predict the occurrence of elevated arsenic concentrations and to manage the aquifers where the concentrations are deemed to be a problem.

Objectives: The investigation was designed to describe the occurrence of arsenic in ground water in the western United States. Specifically, geochemical environments associated with high arsenic concentrations were to be identified and specific geochemical controls on arsenic solubility were to be described for as many of these environments as possible.

Approach: The approach consisted of a regional appraisal and several site-specific field studies. The regional appraisal included a compilation of existing data complemented by additional intensive sampling. The site-specific studies required detailed sampling of solid and liquid phases at selected field sites. Laboratory studies were also made to support the field effort.

Progress and Significant Results, Fiscal Years 1985-88: All field and investigative work was completed in 1987. In addition, three technical papers were given at conferences. The study was terminated earlier than originally planned due to a change of funding emphasis in the national program.

Plans for Fiscal Year 1989: Those reports remaining in review status will be processed through to publication.

Publications, Fiscal Years 1985-88:

Lico, M.S., Welch, A.H., and Hughes, J.L., 1986, Hydrologic, lithologic, and chemical data for sediments in the shallow alluvial aquifer at two sites near Fallon, Churchill County, Nevada, 1984-85: U.S. Geological Survey Open-File Report 86-250, 43 p.

---1987, Geochemistry of ground water in the shallow alluvial aquifer, Carson Desert, western Nevada: 8th Rocky Mountain Regional Meeting, American Chemical Society, Denver, Colo., June 1986, Proceedings, p. 89-109.

Maest, A.S., Wing, Rachel, Nordstrom, D.K., Welch, A.H., and Lico, M.S., 1986, The determination and preservation of dissolved arsenic species in high arsenic waters from Fallon, NV, and Mono Lake, CA (abs.): American Geophysical Union, EOS, v. 67, no. 44, p. 940. 
Welch, A.H., and Lico, M.S., 1986, Arsenic in shallow ground water beneath an irrigated pasture in western Nevada (abs.): American Geophysical Union, EOS, v. 67, no. 44, p. 941.

----1988, Aqueous geochemistry of ground water with high concentrations of arsenic and uranium, Carson River basin, Nevada (abs.): Chemical Geology, v. 70, no. 1/2, p. 19.

-----1988, Arsenic in an alluvial-lacustrine aquifer, Carson Desert, western Nevada, in Ragone, S.E., ed., U.S. Geological Survey Program on Toxic Waste--Ground-water contamination, October 1985, proceedings: U.S. Geological Survey Open-File Report 86-481, p. E-13 - E-18.

Welch, A.H., Lico, M.S., and Hughes, J.L., 1986, Arsenic in ground water of the western United States (abs.): Second Annual Canadian/American Conference on Hydrogeology: Hazardous Wastes in Ground Water-A Soluble Dilemma, Banff, Alberta, Canada, June 1985, Proceedings, p. 81-82.

----1988, Arsenic in ground water of the western United States: Ground Water, v. 26, no. 3, p. 333-347. 


\section{Chloride-Balance Investigation (Project 125)}

Location: Statewide.

Project Chief: Michael D. Dettinger.

Period of Project: 1983-87.

Cooperating Agency: Nevada Division of Water Resources.

Problem: The chloride-balance method of estimating recharge has been applied with generally good results in two interpretive studies in Nevada. The method assumes: (1) the only significant source of chloride in the recharge water is precipitation and dry fallout; and (2) the ground-water sample used to estimate the chloride concentration of recharge water is representative of the amount of chloride entering the system. Despite the fact that the chloride-balance method appears to work well, these assumptions had not actually been tested in Nevada.

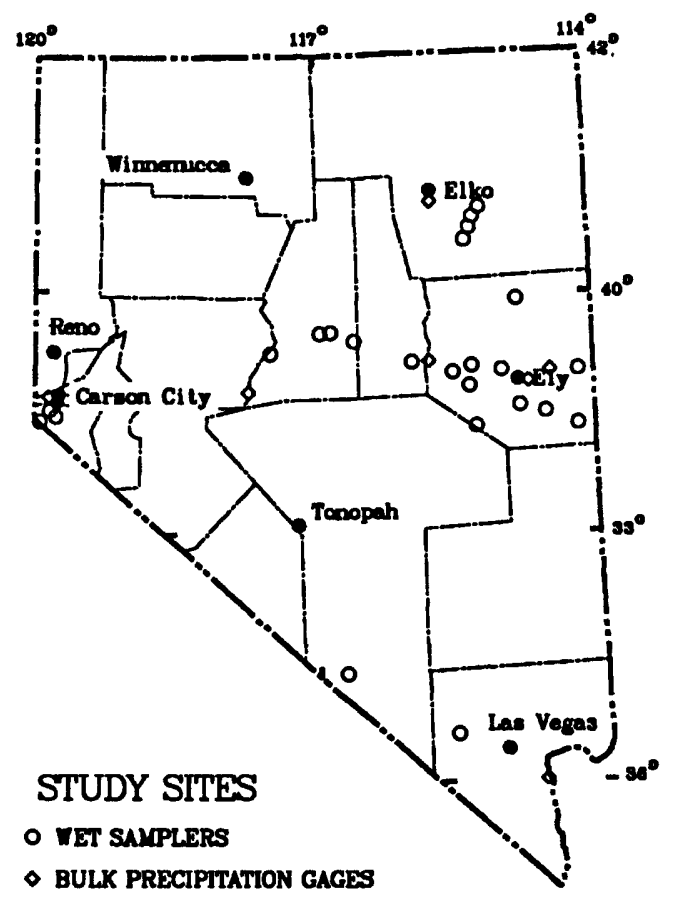

Objectives: The objectives of this study were to assess and test the assumptions on which the chloride-massbalance method of estimating recharge are based.

Approach: The assumptions on which the chloride-balance method of estimating recharge are based were assessed for a semiarid environment using results of existing geochemical studies, existing hydrogeologic data, and new data describing precipitation chemistry. The method was applied to a total of 16 basins in diverse areas of Nevada. Seven bulk-precipitation samplers were located in selected areas of the State and wet-precipitation samples were collected in many more.

Progress and Significant Results, Fiscal Years 1985-88: All field sampling, chemical analysis, interpretation, and report writing related to this project were completed in 1987. The new chloride-balance estimates were compared to previous recharge estimates, with which they showed good agreement. The assumptions on which the chloride-balance method of estimating recharge are based were found to be reasonable for many basins in the State. Errors in delineating recharge-source areas in the carbonate-rock province and large variations in precipitation chemistry were identified as critically limiting factors. Runoff that never recharges some basins generally required only small correction to the recharge estimates.

\section{Publication, Fiscal Years 1985-88:}

Dettinger, M.D., (in press), Reconnaissance estimates of natural recharge to desert basins in Nevada, U.S.A., by using chloride-balance calculations: Journal of Hydrology, v. 106. 


\section{Ground-Water Model for Big Smoky Valley (Project 126)}

Location: Lander and Nye Counties, Nevada.

Project Chief: Elinor H. Handman.

Period of Project: 1983-86.

Cooperating Agency: Nye County Planning Commission.

Problem: Competition is increasing between agricultural and mining interests for the available water resources in northern Big Smoky Valley. An earlier reconnaissance study was conducted in 1970 and a conceptual model of the ground-water system was developed. Newer methods of field investigation and quantitative analysis are now available to better define and quantify the ground-water system.

Objectives: A quantitative analysis of the aquifer system in northern Big Smoky Valley was to be made. A flow model of the basin-fill aquifer was to be con-

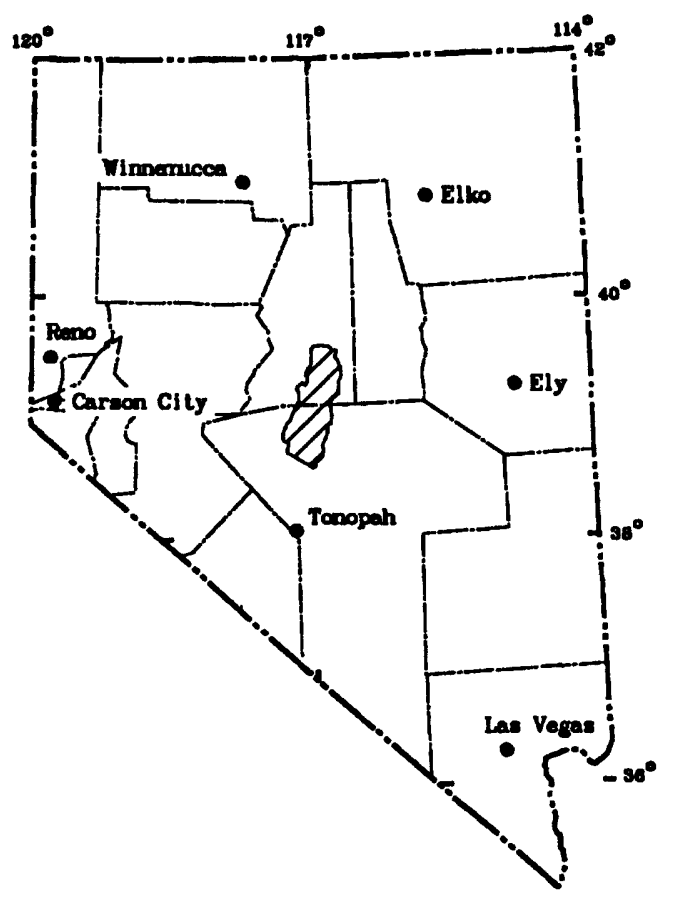
structed to aid in the understanding of basin hydrodynamics.

Approach: Data presented by earlier studies were assembled and supplemented with newly obtained geophysical, geological, and hydrological data. These data were used to develop a preliminary simulation model of the basin. Preliminary model results were then used to guide subsequent data collection to better define the ground-water flow system.

Progress and Significant Results, Fiscal Years 1985-88: All field sampling and modeling were completed in 1986. The report draft was completed and placed in review.

Plans for Fiscal Year 1989: Review of the report will be completed and it will be submitted for USGS approval. 


\section{Nevada Carbonate-Rock Aquifers (Project 128)}

Location: Eastern Nevada.

Project Chief: Donald H. Schaefer, 1987-88;

Michael D. Dettinger, 1984-86.

Period of Project: Continuous since 1984.

Cooperating Agencies: City of North Las Vegas, Desert Research Institute, Las Vegas Valley Water District, Nevada Division of Water Resources, and U.S. Bureau of Reclamation.

Problem: Demand for water in Las Vegas and smaller towns in eastern Nevada is growing, and additional supplies may be needed from ground-water sources outside the local basins. Previous assessments of the water resources of eastern Nevada indicate that the carbonate-rock aquifers are a potential groundwater source, but insufficient data are available upon which to base a decision for the location of major supply wells. Because of the high cost of developing wells in the carbonate aquifers, the location of wells needs to be based on adequate data and sound hydrologic reasoning. Testing and monitoring of selected wells is needed to insure continued availability of water supplies.

Objectives: The carbonate aquifers of eastern Nevada will be studied in order to determine the location and, where possible, the cause of units with high transmissivity, storage capacity, and good water quality. Areas with potential for siting of high-production wells will be selected for test drilling and evaluation.

Approach: Initial studies will focus on the southern part of the carbonate-rock province; later phases will be aimed at the central and northern parts of the carbonate-rock province. Detailed hydrologic, chemical, and geologic analyses of springs and wells already available will be used to gain understanding of the carbonate-rock hydrology and to site other test wells. Test wells to be drilled by the U.S. Geological Survey and U.S. Bureau of Reclamation will be used to determine aquifer properties. Areal studies including remote sensing, geological, geophysical, geochemical, and meteorological surveys will be used in conjunction with the well-test data to define areas in which a high-production well may be sited.

Progress and Significant Results, Fiscal Years 1986-88: In 1987, investigations, which included the siting of three test wells, were completed in Coyote Spring Valley, north of Las Vegas. Studies on the west side of the Sheep Range, northwest of Las Vegas, which included siting of four test wells, were nearly completed in 1988. Several of the wells tapped potentially high-yielding areas and analysis of head data has resulted in modification of existing thinking pertaining to regional flow. Differences in Tertiary basin development between Coyote Spring Valley and the western Sheep range suggest that regionally mappable variations in aquifer development may be present. 
Plans for Fiscal Year 1989: Drilling and testing for the southem part of the study area will be completed in 1989. A summary report of the first 4 years of work will be prepared, and a work plan for moving the study to central Nevada will be developed.

Publications, Fiscal Years 1986-88:

Berger, D.L., Kilroy, K.C., and Schaefer, D.H., 1988, Geophysical logs and hydrologic data for eight well in the Coyote Spring Valley area, Clark and Lincoln Counties, Nevada: U.S. Geological Survey Open-File Report 87-679, 59 p.

Blank, H.R., 1988, Basement structure in the Las Vegas region from potential-field data (abs.): Geological Society of America Abstracts with Programs, v. 20, no. 3, p. 144

Dettinger, M.D., 1987, Influence of Tertiary-age extensional tectonics on present-day regional ground-water flow and discharge in southern Nevada and vicinity (abs.): Geological Society of America Abstracts with Programs, v. 19, no. 6. p. 371-372.

-----(in press), Evaluation of ground-water resources in a structurally extended terrain: Geologic considerations in the eastern Great Basin, Nevada and Utah (abs.): American Geophysical Union, EOS, v. 69, no. 4 .

Emme, D.H., 1986, Aqueous geochemistry and environmental isotope hydrology of the Upper Meadow Valley Wash area, southeastern Nevada: University of Nevada, Reno, unpublished M.S. thesis, 90 p.

Guth, P.L., 1986, Bedrock geologic map of the Black Hills 1:24,000 quadrangle, Nevada: U.S. Geological Survey Open-File Report 86-438, 9 p., 2 sheets.

McBeth, P.E., Jr., and Plume, R.W., 1986, Geophysical exploration of the southern Nevada carbonate terraine: Nevada Water Conference, Las Vegas, February 1986, Poster-Session Display.

Morrin, R.H., Hess, A.E., and Paillet, F.L., 1988, Determining the distribution of hydraulic conductivity in a fractured limestone aquifer by simultaneous injection and geophysical logging: Ground Water, v. 26, no. 5, p. 587-595.

Pierce, H.A., and Hoover, D.B., 1986, Results of natural-source electromagnetic methods for ground water studies near Las Vegas, Nevada: Conference and Exposition, Surface and Borehole Geophysical Methods and Ground Water Instrumentation, Denver, Colo., October 1986, Proceedings, National Water Well Association, p. 354-367.

Thomas, J.M., (in press), Delineation of regional ground-water flow systems in southem Nevada using isotopic and chemical data (abs.): Geological Society of America Abstracts with Programs, v. 20, no. 7. 


\section{Ground-Water Studies, Lake Tahoe Basin, Nevada (Project 129)}

Location: Douglas County and Carson City, Nevada.

Project Chief: Carl E. Thodal.

Period of Project: $1985-88$.

Cooperating Agencies: Douglas County

Department of Public Works and Carson City

Public Works Department.

Problem: Lake Tahoe, which is noted for exceptional water clarity, is experiencing decreasing transparency. Concern about the decreasing transparency has prompted investigations of nutrient sources, especially nitrogen, to the lake. The ground-water component of the Lake Tahoe water and nutrient budgets may be significant, but is not well known. A more precise estimate of the total ground-water nutrient contribution to Lake Tahoe is needed.

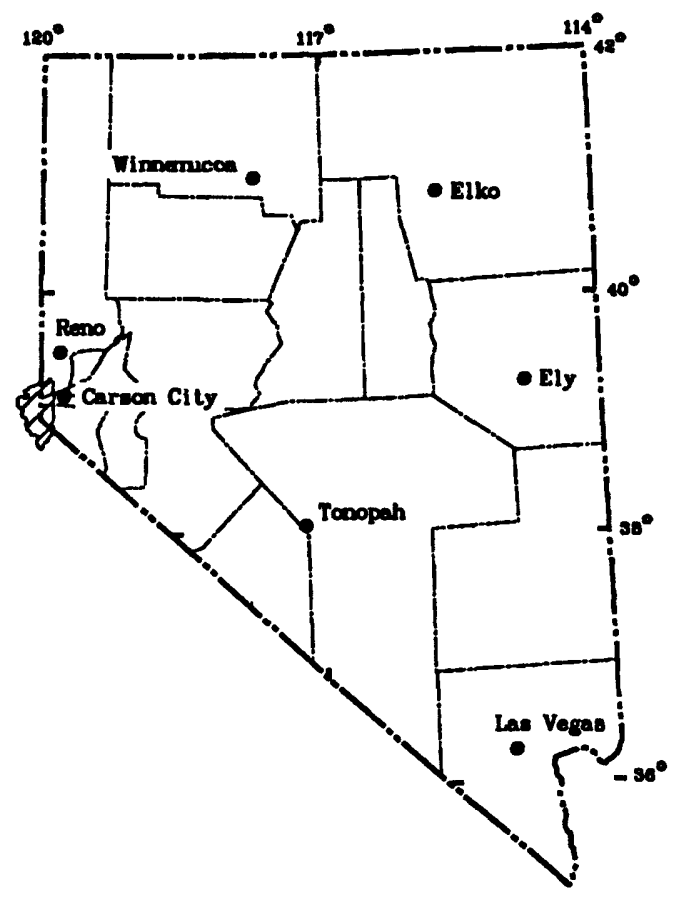

Objectives: The objectives of this study were to compile existing information pertaining to groundwater flow and quality, collect additional data related to ground-water transport of nutrients, and evaluate the potential for nutrient transport in the Douglas County and Carson City, Nev., portions of the Lake Tahoe basin by ground water.

Approach: Existing data and literature on the physical, chemical, and water-quality characteristics of ground-water aquifers were reviewed and compiled along with existing geophysical data. Water-quality data were collected from a network of existing wells and springs, and from new observation wells. Selected tributaries were gaged and sampled during low-flow conditions and assumed to represent ground-water discharge. Aquifer-test data and hydraulic properties estimated from samples of aquifer material were interpreted to determine aquifer properties, and water levels in wells were measured to determine hydraulic gradients to Lake Tahoe.

Progress and Significant Results, Fiscal Years 1985-88: All data collection and interpretation have been completed. Two reports were written and placed in review. A presentation was made at the International Mountain Watershed Symposium held at Lake Tahoe.

Plans for Fiscal Year 1989: Review of both reports will be completed and the reports prepared for publication. 


\section{Nevada Test Site, Weapons Hydrology (Project 130)}

Location: Nevada Test Site, Nye County, Nevada.

Project Chief: William B. Scott, 1987-88;

Terry Katzer, 1986; William D. Nichols, 1985.

Period of Project: Continuing since 1985.

Cooperating Agency: U.S. Department of Energy.

Problem: Nuclear-weapons testing at the Nevada Test Site (NTS) creates the potential for longterm contamination of ground-water supplies by radionuclides. Additionally, design of underground nuclear-test sites requires hydrologic information.

Objectives: The regional ground-water flow system underlying NTS will be characterized. The potential for the extent of radionuclide migration related to nuclear weapons testing will be determined, and hydrologic support will be provided for the

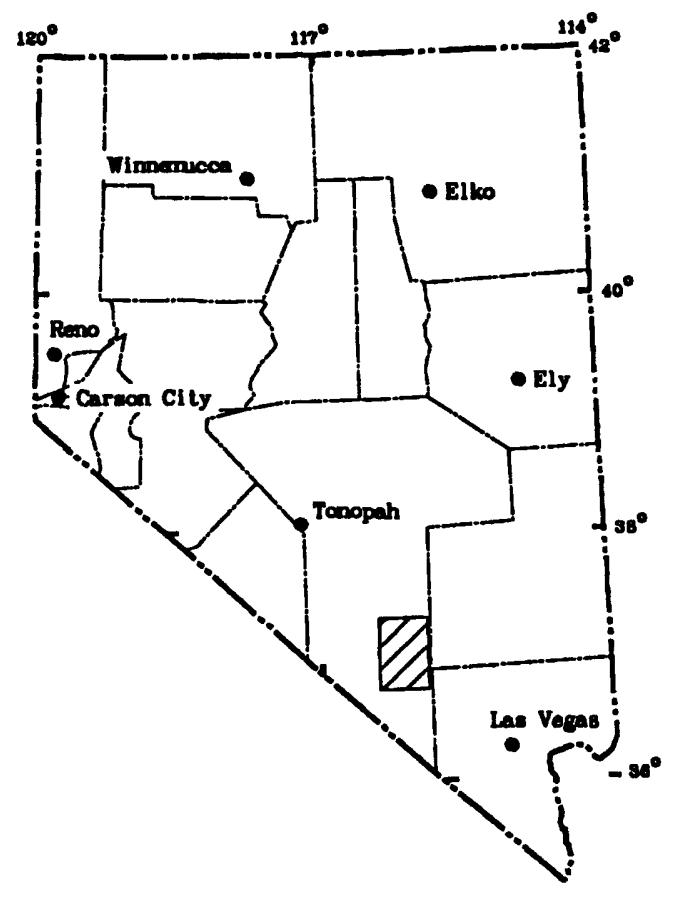
Department of Energy.

Approach: A variety of specially designed studies will be developed and documented to obtain data necessary for the completion of this study. A network of selected test holes and wells will be established to collect hydrogeologic data. Data will be stored in computerized USGS data bases.

Progress and Significant Results, Fiscal Years 1985-88: A test hole was completed to a depth of 3,019 feet on Pahute Mesa, near the western boundary of the NTS. Aquifer tests were performed and the resulting hydrologic data will be used to evaluate ground-water conditions in that area. Maps showing water-table altitudes of Pahute Mesa and Yucca Flat were nearly completed.

Plans for Fiscal Year 1989: Another test hole is planned for the coming year and numerous aquifer tests will be made upon its completion. The maps of Pahute Mesa and Yucca Flat will be completed, and water-level measurements will continue to be collected from a network of observation wells at NTS. A project to assess the potential for developing a Pahute Mesa ground-water flow model will be initiated. Hydrologic expertise will continue to be provided to the USDOE Containment Evaluation Panel and Radionuclide Migration Committee. 


\section{Publications, Fiscal Years 1985-88:}

Arteaga, F.E., Savard, C.S., Johnson, M.E., and Stone, J.C., (in press), Hydrogeologic data from selected wells and test holes in and adjacent to the Nevada Test Site, Nye County, Nevada: U.S. Geological Survey Open-File Report 87-536.

Carman, R.L., and Johnson, M.E., 1986, Analysis of recharge potential at surface disruption sites, Nevada Test Site, Nevada--Study approach: Nevada Water Conference, Las Vegas, February 1986, PosterSession Display.

Savard, C.S., and Morgan, C.O., 1986, Radionuclide migration studies associated with underground nuclear weapon testing, Nevada Test Site, Nevada: Nevada Water Conference, Las Vegas, February 1986, Poster-Session Display.

Scott, W.B., and Morgan, C.O., (in press), Hydrologic activities of the U.S. Geological Survey in support of the radionuclide migration program, Nevada Test Site, Nye County, Nevada, fiscal year 1986: U.S. Department of Energy Summary Report for 1986. 


\section{Water-Resources Evaluation of the Thousand Springs Area (Project 131)}

Location: Elko County, Nevada.

Project Chief: Richard L. Young.

Period of Project: 1985-89.

Cooperating Agency: Elko County.

Problem: Very little basic hydrologic data have been collected for the Thousand Springs area of northeastern Nevada. Interest in the water resources of the area is growing, mainly because of the proposed construction of a coal-fired power plant. Available data are insufficient for estimating the waterresource potential in the area.

Objectives: Surface-water runoff, ground-water recharge, and ground-water discharge measurements are necessary in order to provide information for a hydrologic appraisal of the Thousand Springs area.

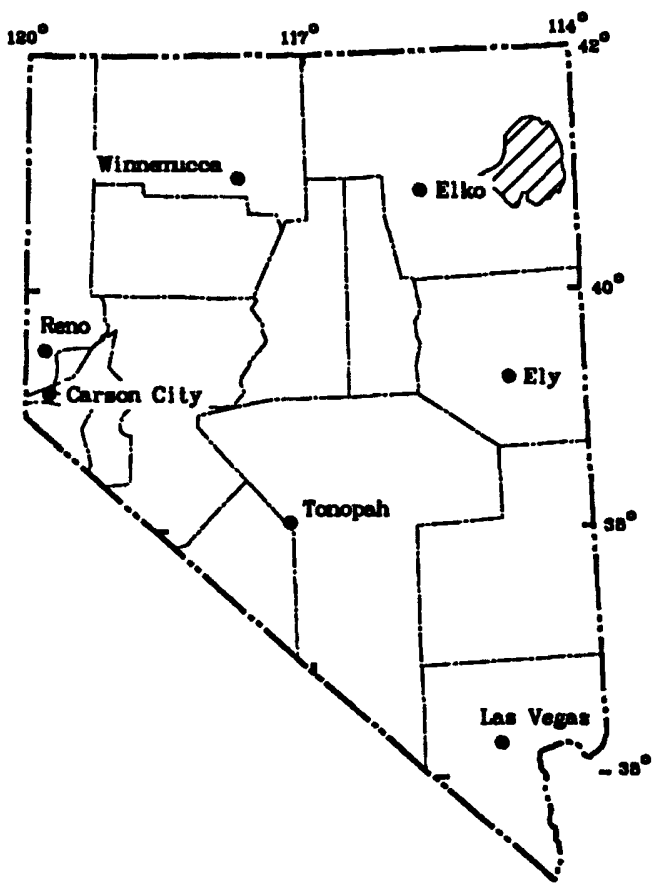
Because future changes in water use may affect water quality, data on surface-water and ground-water quality also will be collected.

Approach: Six data-collection networks will be established: (a) 3 high-altitude precipitation gages; (b) 3 continuous-recording streamflow stations; (c) 4 peak-streamflow stations; (d) staff gages on 2 reservoir spillways; (e) flow measurements at 2 springs; and (f) water-level measurements at 32 well sites.

Progress and Significant Results, Fiscal Years 1985-88: The data-collection networks were established as planned and regular site visits were made. In 1987, one of the streamflow sites was relocated away from the influence of a small diversion dam, and a high-altitude precipitation site was added. Ground-water and water-quality data were collected at a variety of sites in the study area.

Plans for Fiscal Year 1989: Data collection will continue as in the past. A fourth high-altitude precipitation gage and two water-level recorders will be installed at ground-water sites. Seepage measurements and water-quality sampling will be conducted quarterly, and additional ground-water sites will be added as needs are identified.

Publications, Fiscal Years 1985-88:

Frisbie, H.R., La Camera, R.J., Riek, M.M., and Wood, D.B., 1985 [1988], Water-resources data for Nevada, water year 1985: U.S. Geological Survey Water-Data Report NV-85-1, 255 p.

Pupacko, Alex, La Camera, R.J., Riek, M.M., and Wood, D.B., 1988, Water-resources data for Nevada, water year 1986: U.S. Geological Survey Water-Data Report NV-86-1, 263 p.

Pupacko, Alex, La Camera, R.J., Riek, M.M., and Swartwood, J.R., (in press), Water-resources data for Nevada, water year 1987: U.S. Geological Survey Water-Data Report NV-87-1. 


\section{Ground-Water Data for Carson Valley (Project 132)}

Location: Douglas County, Nevada.

Project Chief: David L. Berger.

Period of Project: 1985-88.

Cooperating Agency: Douglas County.

Problem: Water-level measurements used for calibration of a preliminary model of the ground-water and surface-water flow systems in Carson Valley indicated no long-term changes in ground-water levels from 1956 to 1981 . Although 1981 was a dry year and groundwater pumpage was near maximum, the system was not stressed sufficiently to rigorously test the flow model for heavy development conditions. Recent large-scale development in Carson Valley may provide an opportunity to obtain the necessary information for refinement of the existing model and for simulation of development alternatives.

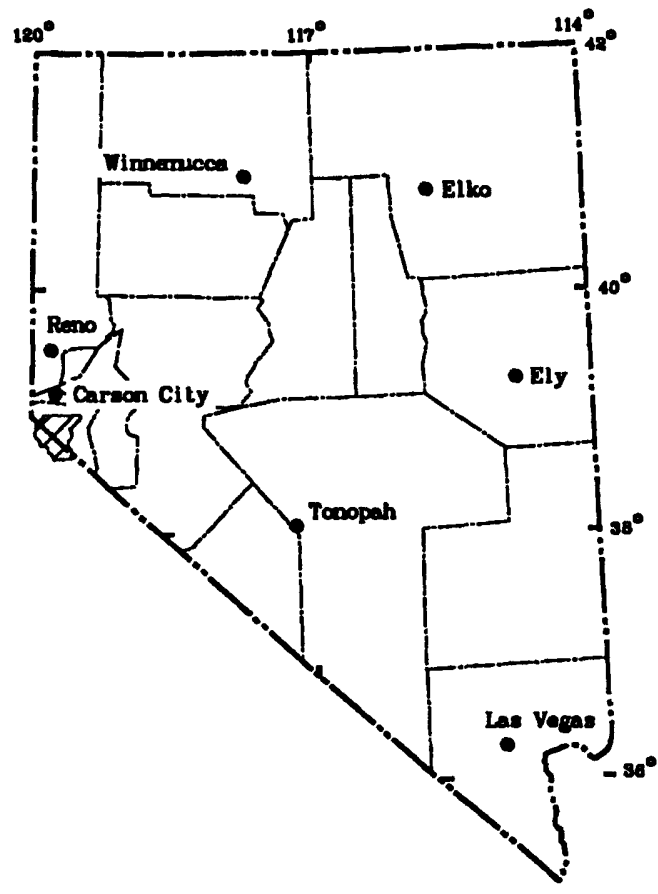

Objectives: A 5-year data base of ground-water level measurements and pumpage information was developed and maintained in Carson Valley. Once adequate data were available, simulations for stressed conditions were to be made on the existing flow model to verify and recalibrate if necessary.

Approach: An observation-well network, established for calibration of the existing flow model, was refined by deleting wells affected by nearby pumping or surface-water bodies, and adding wells near areas of development. Measurements at all sites were made at quarterly intervals except during extreme wet or dry periods, when monthly measurements were made. The effectiveness of the network was evaluated on an annual basis. Ground-water pumpage records were developed on an annual basis from monthly pumpage records or calculated from monthly kilowatt-hour data for agricultural accounts.

Progress and Significant Results, Fiscal Years 1985-88: All ground-water levels for the 1985-88 water years have been entered into the GWSI data base, and pumpage data have been tabulated. In 1988, data on precipitation and sewage import to Carson Valley were also added to the network. Evaluation of data collected during 1985-88 period showed that stresses to the ground-water system were insufficient to warrant recalibration of the ground-water flow model.

Plans for Fiscal Year 1989: The project has been suspended until hydrologic conditions or water withdrawals are such that the system is stressed enough to warrant testing model calibration. A data report summarizing the field measurements will be compiled and published.

\section{Publication, Fiscal Years 1985-88:}

Berger, D.L., 1987, Ground-water levels in water years 1984-86 and estimated ground-water pumpage in water years 1984-85, Carson Valley, Douglas County, Nevada: U.S. Geological Survey Open-File Report 86-539, 16 p. 


\section{Douglas County Ground-Water Quality (Project 133)}

Location: Douglas County, Nevada.

Project Chief: Carl E. Thodal, 1987-88;

Timothy G. Rowe, 1986-87.

Period of Project: $1985-88$.

Cooperating Agency: Douglas County.

Problem: Douglas County, one of the fastest growing counties in the Nation, is experiencing a shift from predominantly agriculture to increasingly residential land use. Ground water is the primary source of domestic water in this area; thus, interest in ground-water quality is increasing. Localized, naturally occurring geochemical processes currently affect ground-water quality in the study area. Changing land-use practices present sources of both potential ground-water quality degradation and increasing demand for potable water.

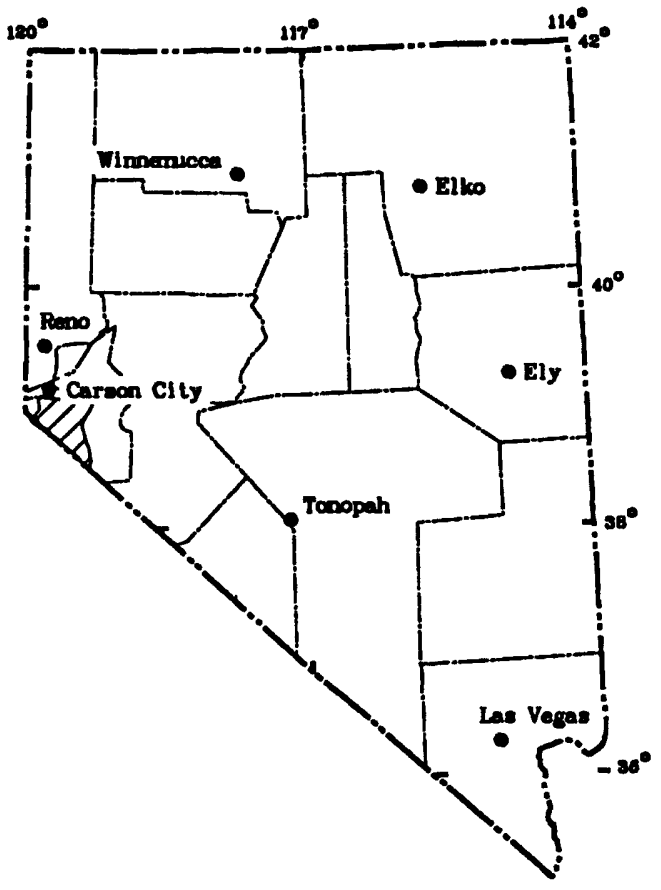

Objectives: This study was to monitor and assess ground-water quality in Carson Valley and the Topaz Lake area for a period of 3 years (1985-88) to characterize seasonal variability and other changes with time.

Approach: Ground-water samples were routinely collected from a network of municipal, domestic, and observation wells throughout the Carson Valley and Topaz Lake areas. The network consisted of 6 primary sites, where samples were collected bimonthly, and 20 sites where samples were collected quarterly to assess long-term trends. Analyses for major ions, nutrients, and organic carbon were made for each sample. Trace constituents for each sample were analyzed bimonthly at each of the primary sites, but only annually at the other 20 sites. Sampling frequency was reduced for the second year of network operation.

Progress and Significant Results, Fiscal Years 1985-88: Ground-water quality monitoring continued as planned through fiscal year 1987, when the data collection part of the program was discontinued. Several sites which showed evidence of organic-compound contamination were resampled and analyzed by the more sensitive gas-chromatography/mass-spectometry method. Four organic compounds were identified at concentrations of 5 micrograms per liter or more. Radon gas analysis was performed at all sites; five sites were above 1,000 picocuries per liter and one was above 10,000 picocuries per liter. Fecal bacteria were detected in water samples from five domestic wells. Two basic-data reports were completed.

Plans for Fiscal Year 1989: The data reports will be prepared for publication, and an interpretive report summarizing results of the study will be written.

\section{Publication, Fiscal Years 1985-88:}

Thodal, C.E., (in press), Data on ground-water quality, Carson Valley and Topaz Lake areas, Douglas County, Nevada, for year ending September 1986: U.S. Geological Survey Open-File Report 88-453. 


\section{Las Vegas Ground-Water Levels (Project 134)}

Location: Clark County, Nevada.

Project Chief: Douglas K. Maurer.

Period of Project: 1985-86.

Cooperating Agency: Las Vegas Valley Water District.

Problem: The increased use of Lake Mead water in Las Vegas will decrease ground-water withdrawals and increase secondary recharge in the basin. A groundwater model for the basin has been developed and calibrated using historical water-level changes. However, calibration might not be sufficient to assess the effects of short-term stresses. An opportunity to measure such a response occurs when major ground-water withdrawals stop in the fall and Lake Mead water (Colorado River) is used, and start again in the spring when demands increase.

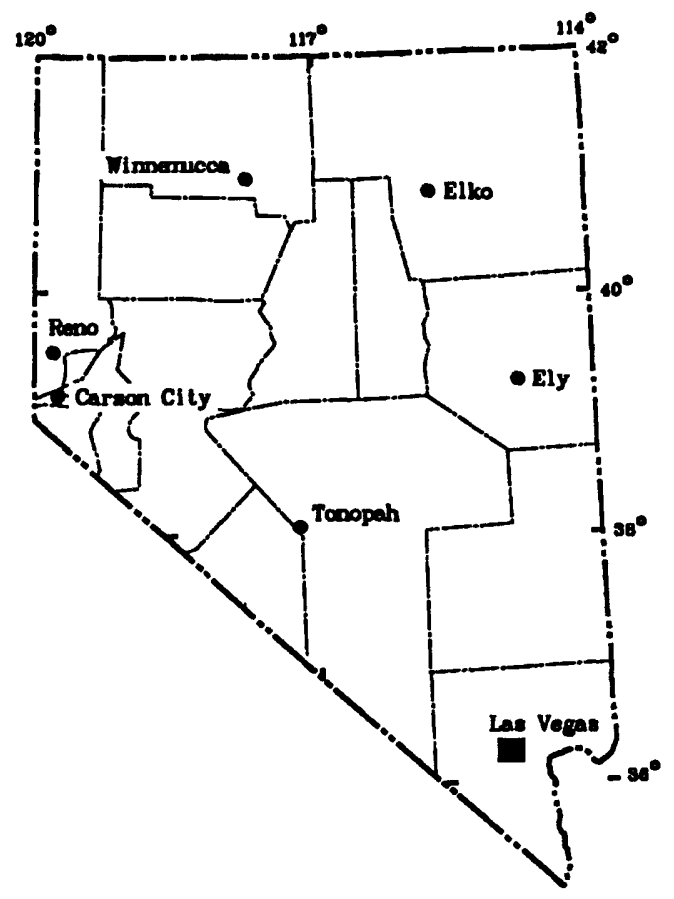

Objectives: The objectives of this study were to:

(1) monitor recovery of the basin-fill aquifer from an organized seasonal stoppage of ground-water withdrawals; (2) measure drawdown in the spring when withdrawals start again; and (3) test an existing model with these short term changes and refine the model parameters as indicated by the new information.

Approach: About 20 wells in the principal deep aquifer were monitored for response to the pulsed stresses, and about 10 wells in the near-surface aquifer were monitored to estimate leakage to or from the principal aquifer. These data were then to be used to improve estimates of aquifer properties and calibrate the model to short-term stresses.

Progress and Significant Results, Fiscal Years 1985-88: The cooperator terminated the project at the end of fiscal year 1986 because artificial-recharge experiments (well injection) were initiated in the study area. The objectives were changed to collection of short-term data. The data report has since been completed.

Publication, Fiscal Years 1985-88:

Maurer, D.K., (in press), Water-level data for Las Vegas Valley, Clark County, Nevada, 1986-87:

U.S. Geological Survey Open-File Report 88-200. 


\section{Gravity and Water Levels (Project 135)}

Location: Statewide.

Project Chief: Donald H. Schaefer.

Period of Project: 1986-88.

Cooperating Agency: Nevada State Senate, Interim Finance Committee.

Problem: Declining water levels in ground-water basins in the western United States are a continuing problem. Wells that monitor water-level declines are often poorly distributed. Additional test holes would be helpful in delineating declines in groundwater levels, but often are too expensive to consider. Gravity measurements may be useful in estimating changes in water levels in areas with few wells because as water is pumped out of a groundwater system, mass is removed but there is usually little or no change in volume. A series of precise gravity measurements in an area of known water-level

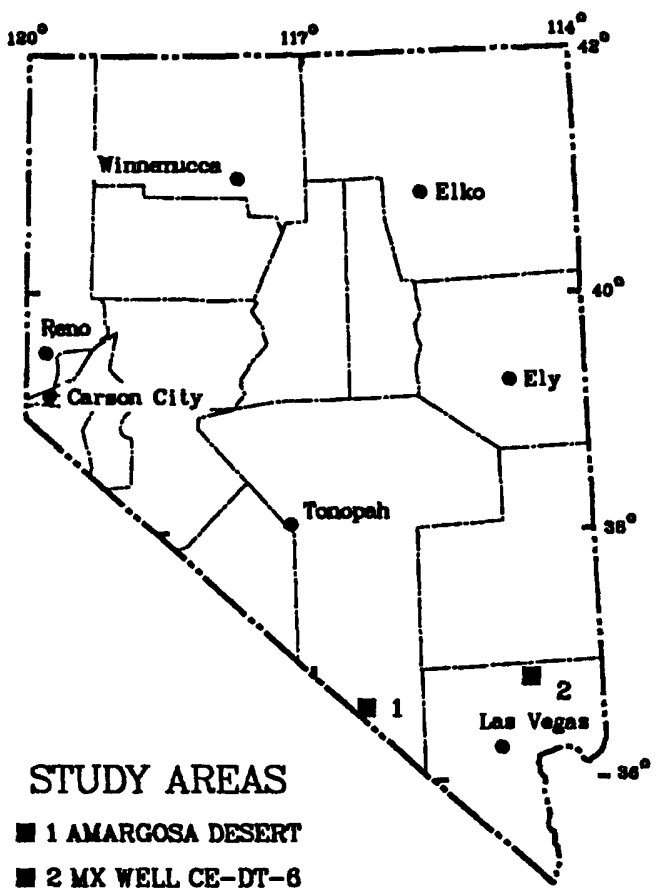
declines might delineate changes in mass due to water withdrawals. Such a technique could then be used to monitor water-level decline in large areas without wells.

Objectives: The objective of this study is to develop procedures that can be used to aid in the determination of water-level declines in large areas without wells.

Approach: A network of 30-50 concrete pads was set up in a few areas experiencing water-level declines, and gravity measurements were taken several times per year at the pads. Each area also included enough wells to allow monitoring of water-level declines so that correlation of water-level declines with changes in gravity measurements could be made. The pad elevations were surveyed before and after the study to determine if any subsidence had taken place, because gravity measurements are very sensitive to such a change.

Progress and Significant Results, Fiscal Years 1986-88: A gravity meter was obtained and fitted with an auto-feedback loop to correct for drift. Pads were set and wells selected at two sites. One study site, in the Amargosa Desert, was later abandoned as well drawdowns were not as great as originally expected. Five sets of gravity measurements were made at the other site, near MX-well CE-DT-6, following a winter of non-use and several summers of heavy use. All water-level data have been entered into the USGS GWSI data base.

Plans for Fiscal Year 1989: Gravity measurements will be continued at 4-month intervals, and a pump test will be made while a tilt-meter is being used to detect elevation changes around the well during pumping. The final report will be completed and submitted for review. 


\section{Carbonate-Rock Streamflow and Recharge (Project 136)}

Location: East-central Nevada.

Project Chief: Charles S. Savard, 1987-88;

Alex Pupacko, 1986.

Period of Project: 1985-88.

Cooperating Agencies: Nevada Department of Conservation and Natural Resources and White Pine County.

Problem: Many streams in Nevada cross a wide variety of geologic materials between source areas in the mountains and ultimate consumption in the closed valleys. It is commonly assumed that little or no aquifer recharge takes place in the mountains and that most aquifer recharge occurs where stream channels cross basin-fill sediments, yet little is actually known about the interactions between streamflow and bedrock aquifers. Recent studies of the carbonate-rock aquifers outcropping in eastern Nevada suggest that they are highly permeable in places. Important gains or losses in streamflow may be occurring in mountain areas where carbonate rocks outcrop.

Objectives: The objective of this study was to attempt to determine geologic effects on streamflow in highmountain basins dominated by carbonate rock.

Approach: Streamflow, precipitation, surface geology, and vegetation were measured and mapped in several similar watersheds located in both carbonate and non-carbonate bedrock. Water budgets were to be developed using modeling techniques for each of the watersheds. Comparison of results from carbonate-rock watersheds with those of non-carbonate rock watersheds were to yield information on the interaction of carbonate rocks and streamflow.

Progress and Significant Results, Fiscal Years 1985-88: Discharge data were collected at stream gages and miscellaneous sites but funding was reduced in 1987 due to the cooperator's higher priorities in other areas. Some field analysis of areas in watersheds contributing to surface runoff was completed and a relation between contributing discharge area and annual mean discharge was developed.

Plans for Fiscal Year 1989: The stream gages will be discontinued and all data will be compiled and published. The funding was discontinued before watershed models could be completed. 
Publications, Fiscal Years 1985-88:

Plume, R.W., 1988, Geologic features that affect the movement of recharge to ground-water basins adjacent to the central Egan Range, White Pine County, Nevada (abs.): Geological Society of America Abstracts with Programs, v. 20, no. 3, p. 221.

Savard, C.S., (in press), Hydrology of four watersheds in the carbonate-rock province, White Pine County, Nevada (abs.): 24th Annual American Water Resources Association Conference, Milwaukee, Wis., November 1988, Program. 


\section{Las Vegas Wash Studies (Project 137)}

Location: Clark County, Nevada.

Project Chief: David E. Prudic.

Period of Project: 1986-87.

Cooperating Agency: U.S. Bureau of Reclamation.

Problem: Las Vegas Wash transports large loads of dissolved solids to the Colorado River due to high levels of native evaporite minerals in the soils and near-surface aquifers, thus contributing significantly to the salinity of the river. Because of this, Las Vegas Wash has been targeted as one of four potential locations for salinity-control projects in the Colorado River Basin. The U.S. Bureau of Reclamation is evaluating two such projects in the Wash: (1) a pipeline to transport cooling water from an industrial complex to the wash, bypassing an unlined, leaky ditch; and (2) a ground-water detention system

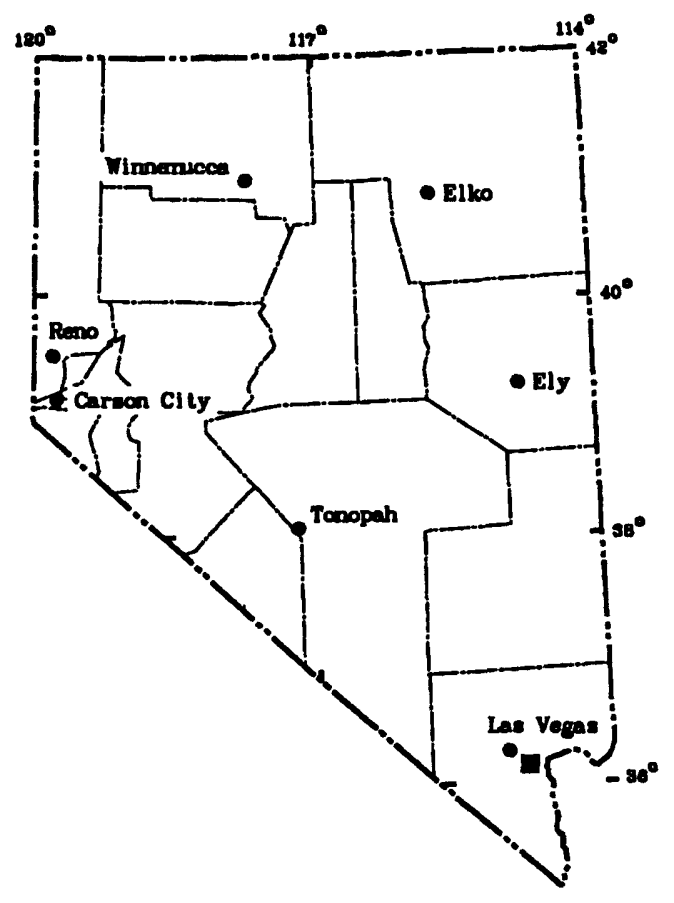
to reduce local flow of saline ground water. The

Bureau requested that the USGS investigate the feasibility of the proposed projects.

Objectives: The objectives of the study were to: (1) determine the effects of replacing a leaky ditch with a pipeline to transport nonsaline waters from the industrial complex near Henderson to Las Vegas Wash, on the salinity of waters in Las Vegas Wash; and (2) to evaluate the effect of installing a ground-water detention basin in the Wash on the salt load transported to Lake Mead.

Approach: Geohydrologic data, water-level measurements, and water chemistry information were collected and applied to calibrate a two-dimensional transport model. The model was used to simulate changes in ground-water flow and salt transport in response to projected effects of the proposed projects.

Progress and Significant Results, Fiscal Years 1985-88: Water-level and water-quality data were collected from 90 shallow wells near the proposed pipeline and from 50 shallow wells near the detention basin. In addition, tests were made to define aquifer properties of many of the 50 wells, and several aquifer-material samples were collected from the wells. Maps and graphs showing trends in ground-water levels and water quality for a 3-year period were prepared. Simulations using a solute-transport model suggest the detention basin concept will not work because the water bearing sediments are too thin and the source and distribution of dissolved solids are unfavorable with respect to the proposed strategy. The pipeline appears to be a more realistic method of reducing salt load in Las Vegas Wash. Reports summarizing the findings were written.

Plans for Fiscal Year 1989: The reports will be reviewed and prepared for publication after approval.

\section{Publication, Fiscal Years 1985-88:}

Burbey, T.J., 1987, Assessment of a salt-reduction strategy for Las Vegas Wash, southern Nevada (abs.): Ground Water, v. 25, no. 5, p. 611 


\section{Southern Nevada Hydrostratigraphy (Project 138)}

Location: Clark and Lincoln Counties, Nevada.

Project Chief: Alan M. Preissler.

Period of Project: 1985-88.

Cooperating Agency: Nevada Bureau of Mines and Geology.

Problem: The extent to which ground-water flow through Paleozoic carbonate rocks is controlled by stratigraphy is important to the larger question of defining flow systems in the carbonate rock aquifers of eastern Nevada. It is well known that most flow is restricted to secondary openings such as joints, fractures, and solution features in the carbonate aquifers. The extent that textural and lithological properties of various carbonate rocks facilitate or impede formation of such secondary features is largely undocumented. Detailed observations of

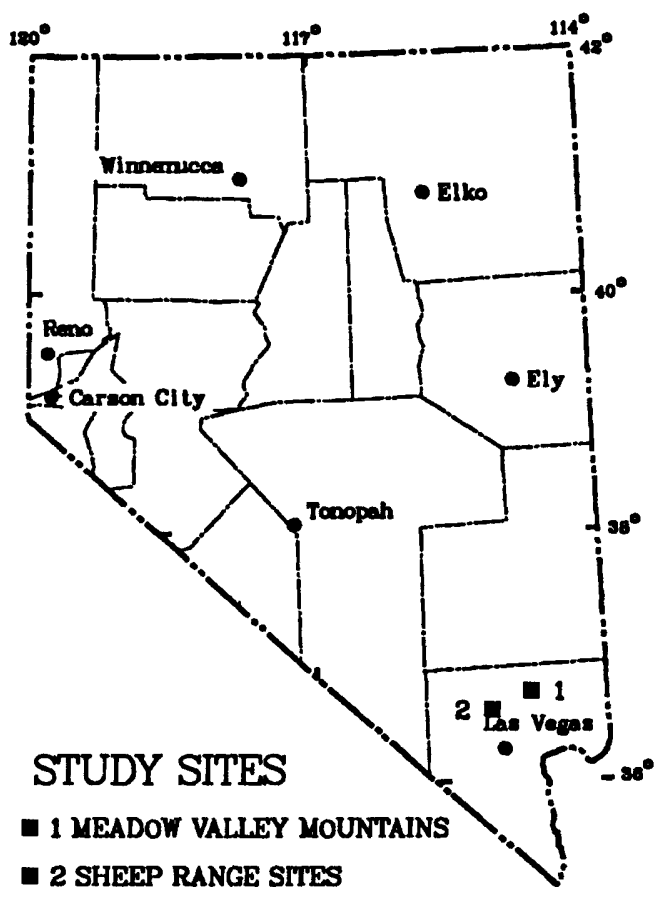
carbonate rocks in outcrop areas are needed to provide useful information on the response of various stratigraphic units to deformation.

Objectives: The objectives of this study were to: (1) describe the textural and lithologic properties of Paleozoic carbonate rocks in order to define hydrostratigraphic units with similar secondary porosity and permeability characteristics; and (2) map variations in thickness and areal extent of hydrostratigraphic units.

Approach: Field assessment of lithologic properties was made, where outcrops in the Meadow Valley Mountains and Sheep Ranges permitted. The tectonic setting of each exposure was described and, where appropriate, rock samples were collected for analysis. Lithologic descriptions and estimates of secondary porosity were made by the most reliable and reproducible methods available. Interpretations concentrated on describing the hydrostratigraphy in terms of secondary porosity and permeability.

Progress and Significant Results, Fiscal Years 1985-88: Secondary porosity and permeability characteristics of the stratigraphic units in the study area have been investigated and hydrostratigraphic units identified. Field work, data analysis, and a first draft of the project report have been completed. The report was placed in review.

Plans for Fiscal Year 1989: Review of the report will be completed and it will be prepared for publication after USGS approval. 


\section{Southern Nevada Evapotranspiration (Project 140)}

Location: Clark and Nye Counties, Nevada.

Project Chief: Michael J. Johnson, 1987-88;

Rita L. Carman, 1985-86.

Period of Project: 1985-88.

Cooperating Agency: Nevada State Senate, Interim Finance Committee.

Problem: Evapotranspiration is the major means of ground-water discharge in arid southem Nevada. Little, if any, work has been done to identify and quantify the amount of ground water lost through evapotranspiration in southern Nevada; the information is needed for hydrologic studies in that area.

Objectives: The objectives of this study were to analyze and quantify evapotranspiration rates in selected areas of southern Nevada.

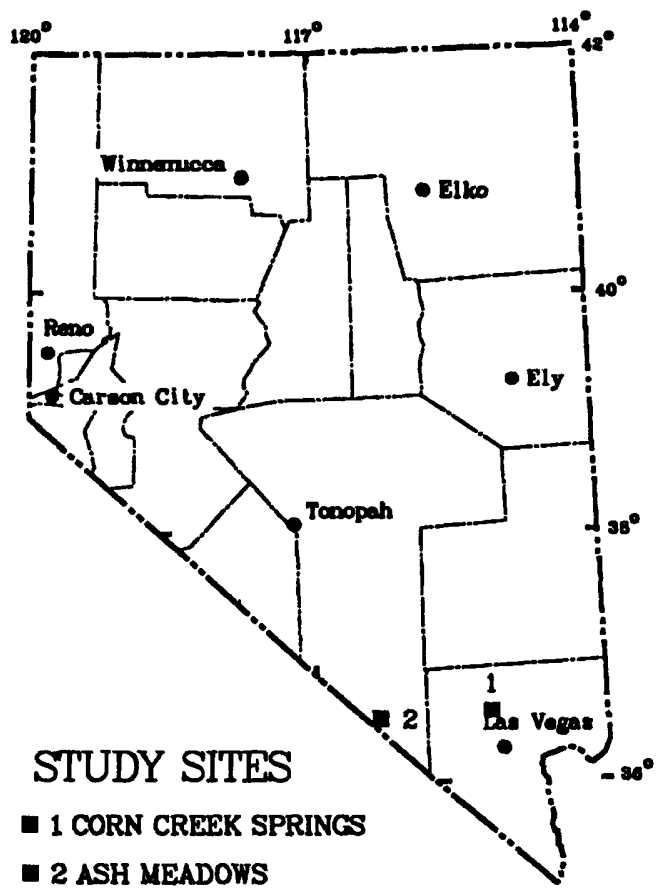

Approach: The eddy-correlation and Penman methods were used to determine evapotranspiration. The eddycorrelation method directly measures evapotranspiration rates by monitoring vapor flux, while the Penman method indirectly measures the evapotranspiration rate by monitoring meteorological parameters used in energy-budget equations. The variability of each parameter from one area to another was also analyzed.

Progress and Significant Results, Fiscal Years 1985-88: Micrometeorological and vapor-flux data were collected at two sites: one near Corn Creek Springs in Las Vegas Valley, and another at Ash Meadows in the Amargosa Desert. A computer program was written to process and display the data. The processed data and processing programs have been stored on magnetic tape to be archived for public access at the National Technical Information Service in Springfield, Va. A data report was written that describes the equipment, theory and equations, and formats used to process and store the data.

Plans for Fiscal Years 1989: An interpretive report that evaluates and presents a summary of the findings will be prepared for review. The data report will be processed through review and prepared for publication. 


\section{Ground-Water Quality in the Carson River Basin (Project 142)}

Location: Western Nevada and eastem California.

Project Chief: Alan H. Welch.

Period of Project: 1986-91.

Cooperating Agency: None (U.S. Geological Survey program). .

Problem: The response of aquifer systems to contamination are largely controlled by a group of factors including geology, hydrology, water withdrawals, and land use. Areas where these factors vary drastically over short distances are most likely to show the largest effects; studies in these areas should produce results with high transfer value to other areas with similar natural and human factors. The Carson River Valley is just such an area.

Objectives: The National Water Quality Assessment

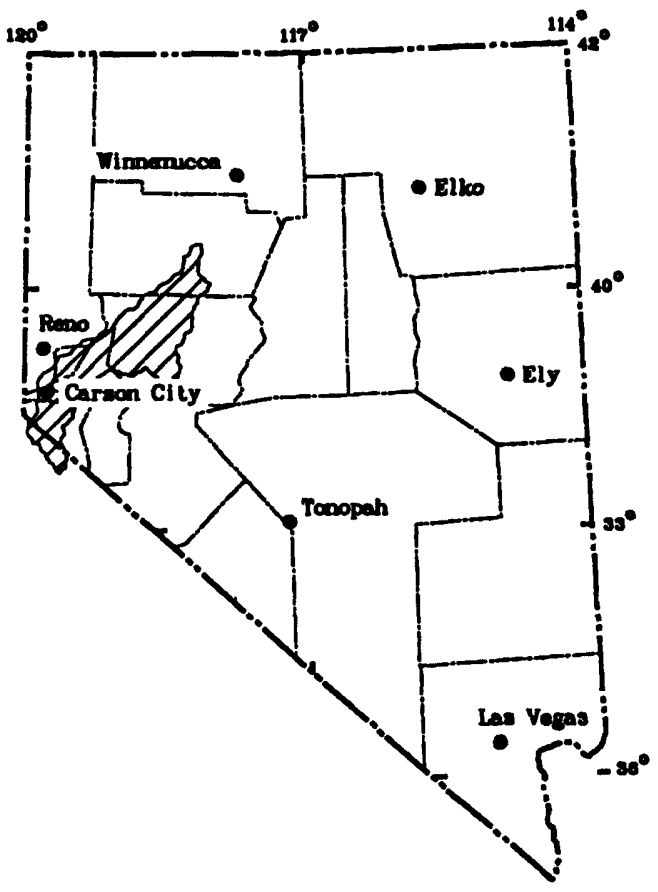
(NAWQA) program is designed to: (1) determine the occurrence and areal distribution of selected trace elements, manmade organic compounds, and other chemical substances that affect the beneficial uses of ground water and that are widespread within the study area; (2) identify and describe zones within the study area that have or are very likely to have particular water-quality problems at the present time; (3) identify and describe zones within the study area that, in relation to land use, and geologic and hydrologic conditions, have varying degrees of susceptibility to future degradation with respect to particular substances; and (4) explore relations of particular types of degraded ground-water quality to land use, hydrology, and other pertinent factors.

Approach: Existing data on ground-water quality in the study area will be inventoried and statistically summarized. Based on this initial analysis, a program to collect additional data to more completely describe the quality of the aquifers with respect to beneficial water use will be designed and implemented. The data will be used to define the relations of observed water quality to geohydrologic and land-use factors.

Progress and Significant Results, Fiscal Years 1986-88: An inventory of available historical data was completed in 1987 and approximately 60 shallow regional wells were drilled. The wells were sampled in 1988 and an additional 60 principal-aquifer wells were drilled and are currently being sampled. Hardware and software for a computer-based Geographic Information System in which to store the data were obtained and brought on line. Several reports neared publication and a paper was presented at the International Geochemical Congress in Paris, France.

Plans for Fiscal Year 1989: A study of an urban area, Eagle Valley, will commence. This study will include drilling 20-30 shallow wells that will be sampled for organic and inorganic constituents. About 55 wells tapping principal aquifers in the Dayton, Churchill, and Carson Desert hydrographic areas will also be sampled. Sampling and analysis of radon will be conducted with an emphasis on Carson and Eagle Valleys. 
Publications, Fiscal Years 1986-88:

Welch, A.H., and Lico, M.S., 1988, Aqueous geochemistry of ground water with high concentrations of arsenic and uranium, Carson River basin, Nevada (abs.): Chemical Geology, v. 70, no. 1/2, p. 19.

Welch, A.H., and Plume R.W., 1987, Water quality assessment of the Carson River ground-water basin, Nevada and California-Project description: U.S. Geological Survey Open-File Report 87-104, 27 p. 


\section{Reconnaissance Study of Irrigation Drainage at the \\ Stillwater Wildlife Management Area (Project 143)}

Location: Churchill County, Nevada.

Project Chief: Ray J. Hoffman.

Period of Project: 1986-88.

Cooperating Agencies: U.S. Department of the Interior program (Bureau of Reclamation, Fish and Wildlife Service, and Geological Survey).

Problem: During the last several years, concem has been increasing about the quality of irrigationdrainage water from western lands and its potential toxic effects on fish, wildlife, and human health. High incidences of reproductive failure and mortality have been observed in waterfowl nesting areas where drainage water is impounded, such as that found at Kesterson Reservoir in California. The Stillwater Wildlife Management Area, fed by irrigation drainage, is likely to be susceptible also.

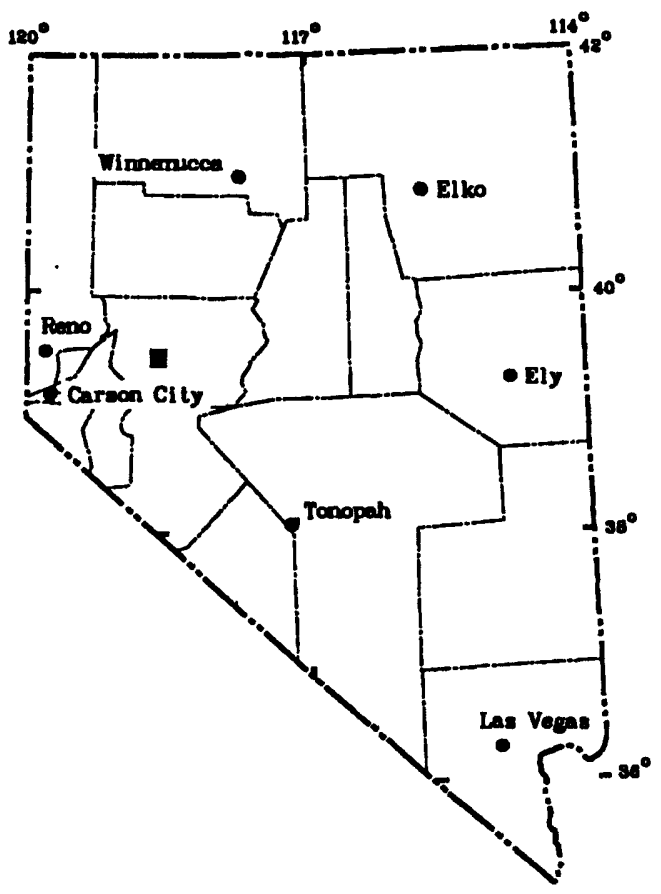

Objectives: The objective of this program is to document whether the quality of irrigation-drainage water from the Newlands Irrigation Project has caused, or has potential to cause, harmful effects on fish, wildlife, or human health in the Stillwater Wildlife Management Area and vicinity.

Approach: A network of approximately 16 surface-water sites and 7 subsurface sites were sampled for physical, biological, and chemical constituents. The data were collected at about quarterly intervals that reflect irrigation practices and significant biologic activities.

Progress and Significant Results, Fiscal Years 1986-88: Sampling in 1986-87 revealed above-background levels of arsenic, boron, chromium, lithium, mercury, molybdenum, and selenium in one or more sampled media (water, sediment, biota). These trace elements are of probable concern to fish, wildlife, and human health in and about the study area. A reconnaissance-level report was written and placed in review, and a work plan for a more detailed study (Project 148) was developed.

Plans for Fiscal Year 1989: The project is complete. The report will continue through the review and publication process.

\section{Publication, Fiscal Years 1985-88:}

Hoffman, R.J., and Hallock, R.J., (in press), Preliminary report of potentially toxic trace elements and pesticides in water, sediment, and biota in and near the Stillwater Wildlife Management Area, Churchill County, Nevada (abs.): Selenium IV--Agricultural Drainage and Implications for the Environment, Berkeley, Calif., March 1987, Symposium Proceedings. 


\section{Ground-Water Study in Honey Lake Valley (Project 144)}

Location: Washoe County, Nevada, and Lassen County, California.

Project Chief: Elinor H. Handman.

Period of Project: 1987-90.

Cooperating Agencies: Nevada Division of Water Resources and Califomia Department of Water Resources.

Problem: As development of the Reno-Sparks area is increasing, nearly all economically available surface water has been allocated and the demand for ground water continues to grow. Use of water from aquifers in the Honey Lake basin is under consideration, but decisions concerning development of the aquifers are complicated by the institutional constraints of withdrawal from an interstate source as well as the physical limitations of ground-water availability in

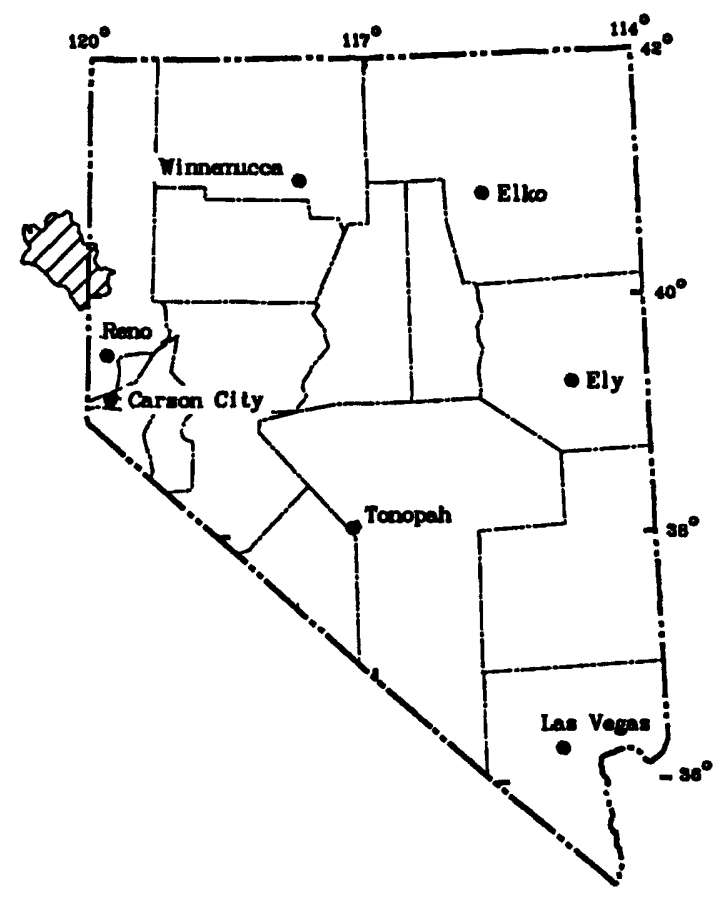
a semiarid area. Therefore, a detailed appraisal of the ground-water budget is needed.

Objectives: The hydraulic characteristics of the aquifers and components of the ground-water budget need to be determined. A digital model will be developed and used to evaluate and quantify the ground-water budget in a selected part of the Honey Lake area near the Nevada-California State line. A report to disseminate the results of the study will be produced in a format and language that is appropriate for use by water managers, water users, and public officials.

Approach: Phase I will include assembly and evaluation of existing data, reconnaissance-level data collection, planning for additional study, and flow-model development. Phase II will involve collection of additional data to fill the needs identified in Phase $\mathrm{I}$, development of a water budget, and revision of the model. Phase III will include completion of the water budget and flow model and preparation of the final report.

Progress and Significant Results, Fiscal Years 1987-88: Work completed in 1987 included: an inventory of wells, selection of stream sites for monthly discharge measurements, a bathymetric study of Honey Lake, gravity and magnetic surveys, and installation of three high-altitude precipitation-storage gages. A preliminary digital flow model was also produced. In 1988, the work included: periodic stream-discharge and water-level measurements, drilling and installation of observation wells, pump tests of production wells, completion of geophysical surveys (audiomagneto-telluric and seismic refraction), evapotranspiration measurements, and publication of a "Water Fact Sheet." The digital-flow model was also refined.

Plans for Fiscal Year 1989: Additional data will be collected and analyzed in 1989, but the main thrust will be interpretation of the data and writing of reports. 
Publication, Fiscal Years 1987-88:

Handman, E.H., 1988, Ground-water resources of Honey Lake Valley, Nevada and California: U.S. Geological Survey Open-File Report 88-306, 2 p. (Water Fact Sheet). 


\section{Geographic-Information System for \\ the Carson River Basin (Project 145)}

Location: Northwestern Nevada and eastern Califomia.

Project Chief: Elizabeth A. Frick.

Period of Project: 1987-90.

Cooperating Agency: None (U.S. Geological Survey Program).

Problem: Within the Carson River basin, environmentally significant concentrations of elements such as arsenic, selenium, molybdenum, boron, lithium, and uranium are present in the unsaturated zone of some, if not most, of the region's basin-fill aquifers.

Few historical data are available on the areal and vertical distribution of trace elements in the soils and aquifers of the Carson basin; however, three ongoing projects (Carson basin NAWQA, Carson basin soil geochemistry, and irrigation drainage at

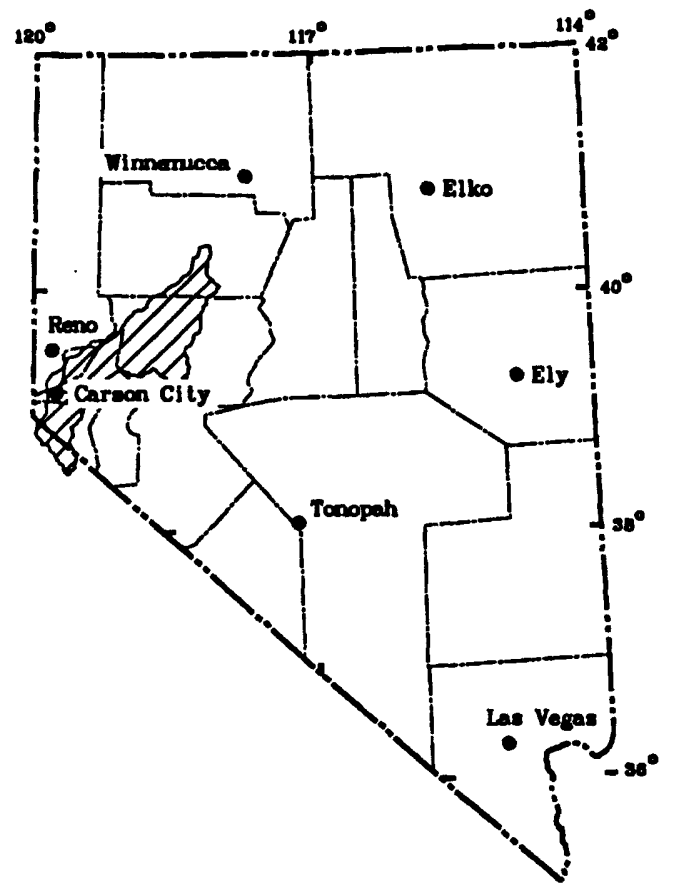
Stillwater Wildlife Management Area) are collecting water- and soil-chemistry data. A computerized Geographic Information System (GIS) can be used as a tool to aid in analysis of relations between the geochemistry of soils and shallow-aquifer materials to the geochemistry of underlying shallow ground water.

Objectives: The objective of this project is to examine whether relations found between solid-phase geochemistry and water chemistry can aid in the regional description of ground-water quality.

Approach: A GIS will be developed for the Carson River basin using computer software to store, manage, and integrate the data. Geology, soil and water chemistry, and land-use data will be assembled and put in digital line-graph form. The GIS will be used to test hypotheses relating areal and vertical patterns in trace-element geochemistry of soils and ground-water quality to each other, to geology, and to land use.

Progress and Significant Results, Fiscal Years 1987-88: A work plan to develop the GIS was written. Approximately 20 data layers were completed. Each data layer contains cartographic representation of one type of information, such as geology. Base maps at a scale of 1:100,000 and 1:250,000 were created, and a statistical analysis on the solid-phase geochemistry data was begun.

Plans for Fiscal Year 1989: Several geochemistry data layers will be updated as laboratory results arrive. Data analysis will be completed and software will be written to allow several users to access the system. A report discussing the GIS and the results of the statistical analyses will be written and placed in the review process. 


\section{Publication, Fiscal Years 1987-88:}

Frick, E.A., 1987, Geographical Information System for interpreting and displaying geochemistry of soil. shallow aquifer material, and ground water in the Carson River basin, Nevada and California--Project objective and plans, in Abstracts of papers presented at the Geographical Information Systems Symposium, Reston, Va., June 1987: U.S. Geological Survey Open-File Report 87-314, p. 32-33. 


\section{Geographic-Information System for the \\ Lake Tahoe Basin (Project 146)}

Location: Lake Tahoe Basin, eastern California and western Nevada.

Project Chief: Elizabeth A. Frick.

Period of Project: 1987-90.

Cooperating Agency: Tahoe Regional Planning Agency.

Problem: Resource assessment, land and resource management, and basic research relating to hydrology in the Lake Tahoe Basin have been hampered by the lack of a common, basin-wide data base. Data collected for diverse purposes at varying scales are stored by individual agencies with different reporting conventions and standards. Previously, a great deal of effort has been expended to reduce duplication in monitoring efforts and to crossreference data sources for the basin. Existing data need to be recompiled at uniform scales $(1: 6,000$, and

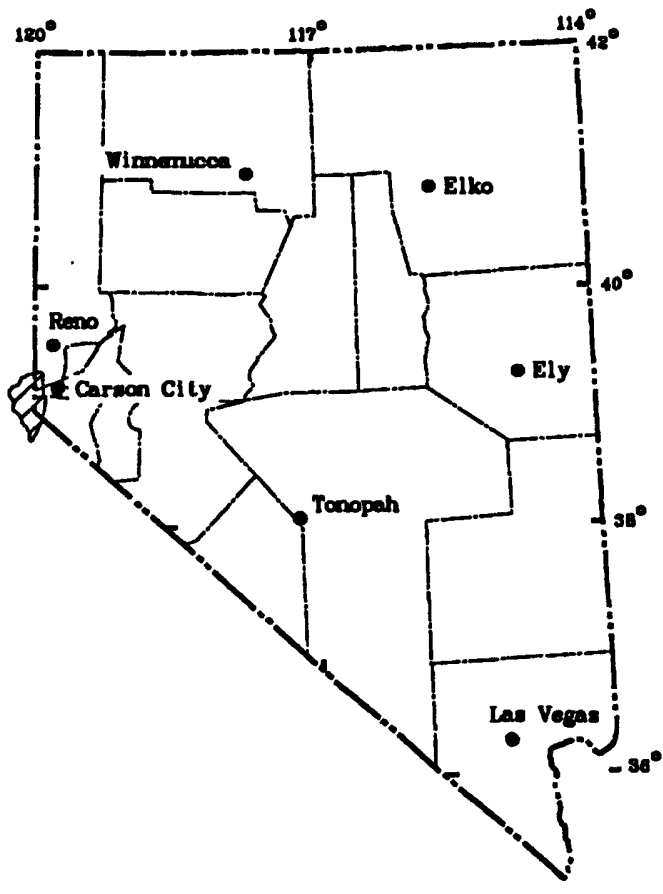
1:24,000) and automated into a consistent geographic-information system.

Objectives: The objective of this study is to develop the Tahoe Environmental Geographic-Information System (TEGIS) that can be used to facilitate water-resource data exchange between the U.S. Geological Survey and other agencies, particularly Tahoe Regional Planning Agency (TRPA). TRPA will use the TEGIS to manage, analyze, and display data in support of the agency's land, water, and air resourcemanagement missions.

Approach: A pilot GIS will be designed, tested, and refined for the Washoe County part of the Lake Tahoe Basin (31 square miles). The major steps in completing the pilot project will be the definition of needs and objectives, data-base design, data inventory and compilation, thematic mapping, map integration and automation, GIS demonstrations, and completion of software to allow simultaneous multiuser access. After completion of the pilot project, the GIS will be expanded to other parts of the basin in the priority order set by the U.S. Geological Survey and Tahoe Regional Planning Agency.

Progress and Significant Results, Fiscal Years 1987-88: The data-base design was completed. Mapping, integration, and automation of the GIS system was nearly completed for the Washoe County section of the study (pilot project). Land-use, parcel, hydrology, integrated terrain units, and administrative units are all included in the GIS. The data base was demonstrated to TRPA.

Plans for Fiscal Year 1989: The pilot project is to be completed and a final presentation of the data base will be presented to TRPA management. The USGS and TRPA will prioritize the remaining areas of the Tahoe basin, and data layers--such as land use--will be added to the GIS in fiscal year 1989. Two poster sessions will be presented at a computer-graphics conference, May 1989. 


\section{Stream Monitoring in the Lake Tahoe Basin (Project 147)}

Location: Lake Tahoe basin, California and Nevada.

Project Chief: Carl E. Thodal, 1989;

Kerry T. Garcia, 1987-88.

Period of Project: 1987-93.

Cooperating Agency: Tahoe Regional Planning Agency.

Problem: The requirements for streamflow and waterquality monitoring data are increasing along with the increasing fiscal commitment of State and Federal agencies to the improvement of environmental conditions in the Lake Tahoe basin. Water-quality monitoring, with emphasis on nutrient loading from tributary streams, is essential to document the local and regional effectiveness of environmental programs, to meet the requirements of the Regional Plan of the Tahoe Regional Planning Agency (TRPA), and to assess compliance with the water-quality management ("208")

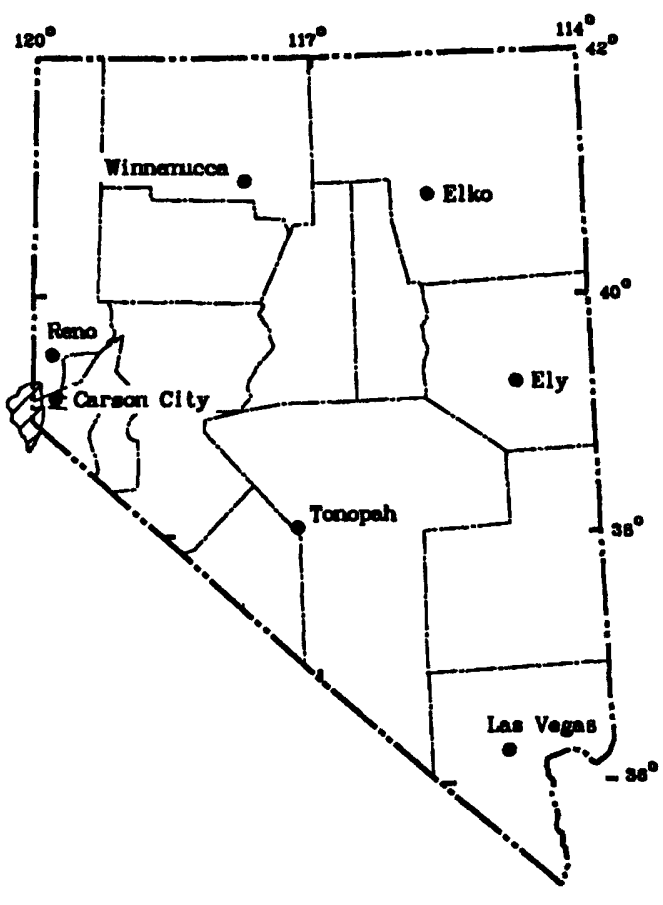
plan for the region.

Objectives: The objectives of this study are to: (1) provide a long-term data base of streamflow and of sediment and nutrient loadings from major tributary streams to Lake Tahoe; (2) determine the sources of streamflow and of sediment and nutrient loads; (3) describe the mechanisms by which sediment and nutrient loads are transported to and by streams; (4) develop methods of estimating total streamflow and nutrient and sediment loads transported by streams to Lake Tahoe; (5) support assessment of the effects of land use and development in the Lake Tahoe Basin on the measured tributary loadings.

Approach: The existing network of sites will be expanded, the level of sampling will be increased, and data analysis will be improved to better define the nutrient input to Lake Tahoe from tributary streams. An additional station will be added to the Lake Tahoe Interagency Monitoring Program (LTIMP) network to increase the total stations to 10, 5 each in California and Nevada. The monitored nutrients will be expanded to fully define the speciation of nitrogen and phosphorus in the stream loadings. Analyses of both dissolved and suspended loads will be made to further delineate potential sources of nutrients.

Progress and Significant Results, Fiscal Years 1987-88: Sampling began in 1988 at all stations at approximately monthly intervals and these data are now stored in the NWIS databases.

Plans for Fiscal Year 1989: A station at Edgewood Creek will be added to the LTIMP network, and a sampling methodology will be defined. Analysis for organic nitrogen and phosphorus will be added in 1989. A data report will be written, and an evaluation of the methods used for computation of sediment and nutrient loadings will commence. The data also will be published in the annual water-data reports for both Nevada and California. 


\section{Detailed Study of Irrigation Drainage at the Stillwater Wildlife Management Area (Project 148)}

Location: Churchill County, Nevada.

Project Chief: Michael S. Lico.

Period of Project: 1987-90.

Cooperating Agencies: U.S. Department of the Interior program (Bureau of Reclamation, Fish and Wildlife Service, and Geological Survey).

Problem: The Stillwater Wildlife Management Area (SWMA) is the largest marsh in Nevada and is maintained mostly by irrigation-return flow drained from fields in the Fallon area. Elevated concentrations of potentially toxic trace elements have been found in this drain water. The geochemical processes controlling the mobilization, transport, and fate of these trace elements are poorly understood.

Objectives: The objectives of this study are to:

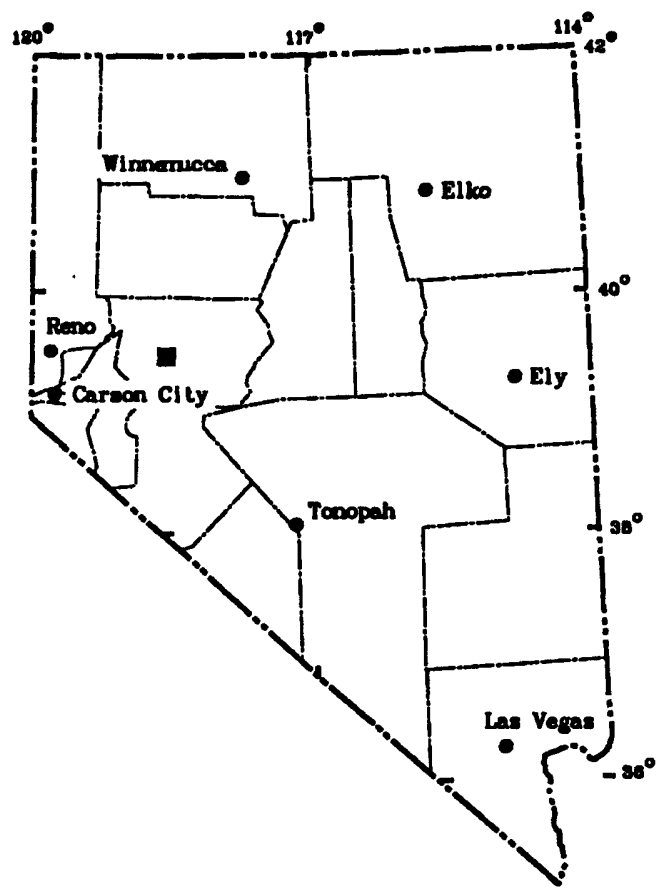
(1) determine for selected areas the occurrence, distribution, and geochemical processes responsible for mobilization and transport of toxic constituents to SWMA and Fernley Wildlife Management Area (FWMA); and (2) collect baseline water-quality and bottom-material data in areas where none currently exist.

Approach: Monthly water-quality sampling at monitored sites will be used to distinguish areas which contribute trace elements to SWMA and FWMA. Those areas which contribute relatively large loads of trace and toxic materials will be studied by continuous monitoring of input drains. Water levels in wells will be measured to determine ground-water flow directions, and additional wells will be installed along ground-water flow paths for detailed sampling. Ground-water seepage on lake bottoms will be measured, and bottom sediments and cores will be characterized. Geochemical models will be used to evaluate sediment-water interactions.

Progress and Significant Results, Fiscal Years 1987-88: Reconnaissance sampling of 38 surface-water sites was completed in the spring and fall of 1988. Ten water-quality sampling wells were augered at FWMA. Core and bottom-material samples were collected and analyzed for trace elements. Continuous-recording monitors to collect data on $\mathrm{pH}$ and specific conductance were installed on a drain in FWMA, and at several sites in SWMA.

Plans for Fiscal Year 1989: Reconnaissance sampling of surface-water sites will continue. Observation wells will be installed in SWMA, and sampling and water-level measurements will commence. Automatic samplers and stream gages also will be located at FWMA and at SWMA. Core materials from FWMA and SWMA will be characterized by $X$-ray, mineralogical, and chemical methods. Seepage measurements will be made on the bottom of South Pond at FWMA and Lead Lake at SWMA. Presentations will be made at scientific conferences, and a progress report by the U.S. Fish and Wildlife Service will be published. 


\section{Publication, Fiscal Years 1985-88:}

Rowe, T.G., and Hoffman, R.J., (in press), Wildlife kills in the Carson Sink, western Nevada, winter of 1986-87, in National water summary 1987--Hydrologic events and water supply and demand: U.S. Geological Survey Water-Supply Paper 2350. 


\section{Effects of Ground-Water Withdrawals \\ on the Maggie Creek Area (Project 149)}

Location: Elko and Eureka Counties, Nevada.

Project Chief: Russell W. Plume.

Period of Project: 1988-91.

\section{Cooperating Agency: Nevada Division of Water Resources.}

Problem: The Maggie Creek area, including the town of Carlin, is in an area of rapidly developing mining operations. In 1985, water consumption for mining and milling operations was less than 800 acre-feet per year. An estimated 5,650 acre-feet will have been used in 1988 and this will increase to more than 9,000 acre-feet in 1989. Mining and milling activities are expected to continue at 1989 levels for 1020 years. Specific concerns are: (1) potential for reduction of flow at Carlin Springs, the main water source for the town; (2) potential for induced

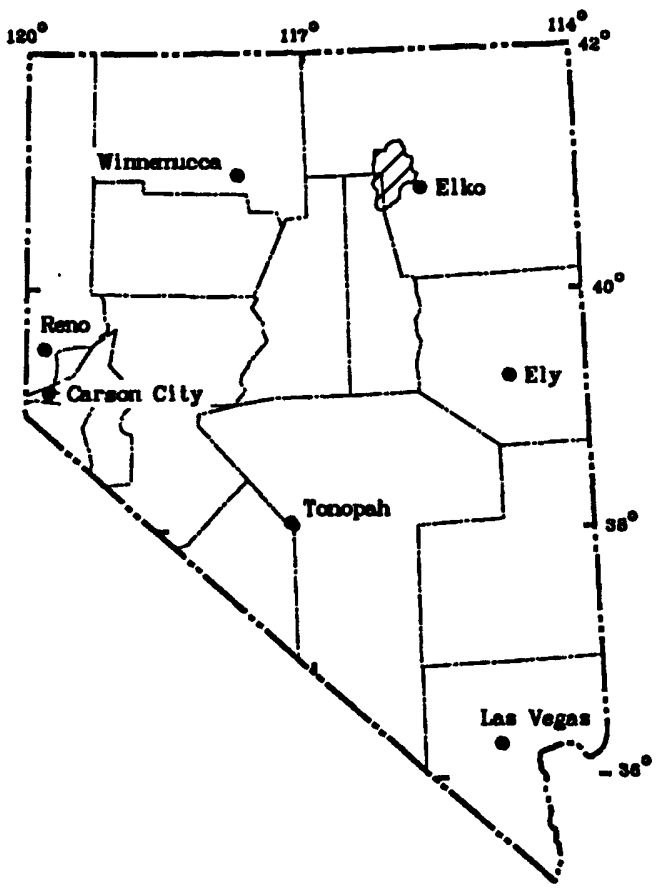
leakage from the channels of Maggie Creek and the Humboldt River, which could impact downstream water users; and (3) uncertainty regarding the long-term response of the ground-water system in the area to sustained larger withdrawals.

Objectives: The objectives of the Maggie Creek study are to: (1) document hydrologic conditions, including ground-water levels, water quality, surface flows, pumpage, and any response to pumping; (2) update groundwater budgets; (3) evaluate the lower basin to determine hydrologic characteristics, geometric boundaries, and interaction of the aquifers; (4) develop a conceptual model of the flow system in the lower basin that is compatible with available geologic, hydrologic, geochemical, and geophysical information; (5) evaluate probable impacts of pumping during the anticipated life of the mining operation; and (6) point out areas that, on the basis of geologic and hydrologic information, appear to have potential as artificial-recharge sites.

Approach: The project was initiated in late 1988 with a literature search, identification of sampling protocol, location of sampling sites, and purchase of necessary field equipment. Intensive hydrologic, geologic, and geophysical data collection and analysis will continue in 1989-90 and a report summarizing the study findings will be completed during the first half of fiscal year 1991.

Progress and Significant Results, Fiscal Year 1988: The literature review was completed, data-collection networks were established, and hydrologic sampling was started.

Plans for Fiscal Year 1989: Aeromagnetic and hydrogeologic maps will be prepared, and areas needing more data will be identified. A compilation of recent pumpage data for Carlin Springs and the mine wells will be made and augmented with detailed measurements. Water levels in wells, water chemistry, and streamflow will be measured. Seismic surveys of lower Maggie Creek basin will be made to get estimates of depth to bedrock. A draft outline of the final report will be prepared. 


\section{Ground-Water Appraisal of Smoke Creek Desert (Project 150)}

Location: Washoe County, Nevada.

Project Chief: Douglas K. Maurer.

Period of Project: 1988-92.

Cooperating Agencies: California Department of Water Resources and Regional Water Planning and Advisory Board--Reno-Sparks and Washoe County.

Problem: Smoke Creek Desert is one of several sparsely developed basins under consideration as a potential source of water for the rapidly growing population of Reno, Sparks, and surrounding areas. An estimated 13,000 acre-feet of water recharges the basin, but estimates of the amount and type of discharge are significantly less well defined. The large area of the playa relative to the size of the basin suggests that a large part of discharge is by evapotranspiration--water which could be put to more

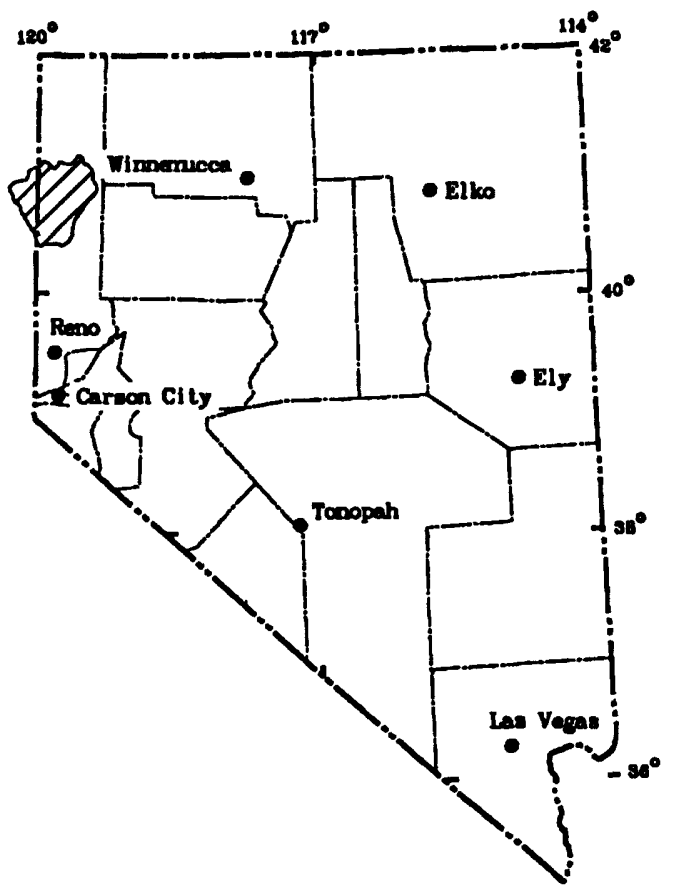
beneficial use within Washoe County. A more detailed assessment of the amount and quality of water available is necessary before management decisions pertaining to development of this water resource can be made.

Objectives: The objectives of this study are to: (1) reappraise the water budget of Smoke Creek Desert; (2) define the geometric boundaries and hydrologic properties of the principal aquifers; (3) determine the general water quality of surface and ground water in the basin; and (4) develop a conceptual model of the hydrologic system in order to aid in a better understanding of the occurrence and movement of ground water.

Approach: A major deficiency of hydrologic and geologic data to support interpretive studies exists because of the undeveloped nature of Smoke Creek Desert. A major emphasis must be placed on data collection during this study, particularly data that relate to recharge, discharge, water quality, and basin and aquifer geometry. Existing wells and springs will be inventoried and a ground-water monitoring network will be established. Precipitation gages will be installed at selected sites and a site to measure evapotranspiration from the playa will be established. A streamflow network will be installed. Water samples will be collected for chemical analysis from surface- and ground-water sources. Geophysical techniques will be used to determine aquifer geometry.

Progress and Significant Results, Fiscal Year 1988: A literature search and assembly of needed equipment, maps, and supplies was started and ground-water and streamflow network sites were selected. A reconnaissance of flowing wells in the basin shows specific conductance ranges from about 200 to over 4,000 microsiemens per centimeter with values decreasing with well depth at some sites and increasing with depth at others. Specific conductance was also found to increase with proximity to the playa. Results of radon sampling show activities range from 20 to 1,700 picocuries per liter with higher values near the Granite Range at the north end of the basin. 
Plans for Fiscal Year 1989: The literature search will be expanded to include hydrologic, climatic, geologic, geochemical, geophysical, and remote-sensing data. Monitoring of ground-water levels and streamflow networks will continue. Bulk precipitation gages will be installed. Water samples will be collected for chemical analysis during spring and fall, when high- and low-flow conditions exist. The conceptual model will be started. 


\section{WATER-RELATED PUBLICATIONS, NEVADA DISTRICT, FISCAL YEARS 1985-88}

Andraski, B.J., (in press), Physical properties of trench backfill at a simulated burial site for low-level radioactive waste near Beatty, NV (abs.): 80th Annual Meeting, American Society of Agronomy, Anaheim, Calif., December 1988, Program of Agronomy Abstracts, v. 80.

Arteaga, F.E., 1985, Use of Landsat data in estimating evapotranspiration rates of Sierra Nevada vegetation in Washoe Valley, Nevada: Symposium on Tropical Hydrology, American Water Resources Association, and Second Caribbean Islands Water Resources Congress, San Juan, P.R., May 1985, Poster-Session Display.

Arteaga, F.E., (in press), Cost effectiveness of the stream-gaging program in Nevada: U.S. Geological Survey Water-Resources Investigations Report 87-4213.

Arteaga, F.E., Savard, C.S., Johnson, M.E., and Stone, J.C., (in press), Hydrogeologic data from selected wells and test holes in and adjacent to the Nevada Test Site, Nye County, Nevada: U.S. Geological Survey Open-File Report 87-536.

Bedinger, M.S., Harrill, J.R., Langer, W.H., Thomas, J.M., and Mulvihill, D.A., 1984, Maps showing groundwater levels, springs, and depth to ground water, Basin and Range province, Nevada: U.S. Geological Survey Water-Resources Investigations Report 83-4119-B, 2 sheets, scale 1:500,000.

Bedinger, M.S., Harrill, J.R., and Thomas, J.M., 1984, Maps showing ground-water units and withdrawals, Basin and Range province, Nevada: U.S. Geological Survey Water-Resources Investigations Report 83-4119-A, 2 sheets, scale 1:500,000.

Bell, J.W., and Katzer, Terry, 1984, Quaternary tectonic history of the IXL Canyon quadrangle, Dixie Valley, Nevada (abs.): Geological Society of America Abstracts with Programs, v. 16, no. 6, p. 442.

----1987, Surficial geology, hydrology, and late Quaternary tectonics of the IXI Canyon area, Nevada--As related to the 1954 Dixie Valley earthquake: Nevada Bureau of Mines and Geology Bulletin 102, 52 p.

Bell, J.W., Watters, R.J., and Glancy, P.A., (in press), Engineering geology of the Reno-Lake Tahoe area, Nevada, in Engineering geology of western United States urban centers [for 28th International Geological Congress, July 1989]: Washington, D.C., American Geophysical Union, Field Trip Guidebook T181.

Berger, D.L., 1987, Ground-water levels in water years 1984-86 and estimated ground-water pumpage in water years 1984-85, Carson Valley, Douglas County, Nevada: U.S. Geological Survey Open-File Report 86-539, $16 \mathrm{p}$.

Berger, D.L., Kilroy, K.C., and Schaefer, D.H., 1988, Geophysical logs and hydrologic data for eight wells in the Coyote Spring Valley area, Clark and Lincoln Counties, Nevada: U.S. Geological Survey Open-File Report 87-679, $59 \mathrm{p}$.

Berggren, Gregg, and Harrill, J.R., 1986, Vegetation, South Lake Tahoe quadrangle [Nevada and California]: Nevada Bureau of Mines and Geology Urban Maps Series, South Lake Tahoe Folio, Map 2Ae, scale 1:24,000. 
Berggren, Gregg, and Harrill, J.R., 1986, Vegetation, South Lake Tahoe quadrangle, Nevada and California: Nevada Bureau of Mines and Geology Open-File Report 86-3 [supplement to Urban Map 2Ae], 2 p.

Blank, H.R., 1988, Basement structure in the Las Vegas region from potential-field data (abs): Geological Society of America Abstracts with Programs, v. 20, no. 3, p. 144.

Blodgett, J.C., Oltmann, R.N., and Poeschel, K.R., 1984, Estimation of streamflow for selected sites on the Carson and Truckee Rivers in California and Nevada, 1944-80: U.S. Geological Survey Water-Resources Investigations Report 84-4058, $223 \mathrm{p}$.

Brown, W.M., III, Nowlin, J.O., Smith, L.H., and Flint, M.R., 1986, River-quality assessment of the Truckee and Carson River system, California and Nevada--Hydrologic characteristics: U.S. Geological Survey Open-File Report 84-576, 201 p.

Bunch, R.L., and Harrill, J.R., 1984, Compilation of selected hydrologic data from the MX missile-siting investigation, east-central Nevada and western Utah: U.S. Geological Survey Open-File Report 84-702, $123 \mathrm{p}$.

Burbey, TJ., 1987, Assessment of a salt-reduction strategy for Las Vegas Wash, southern Nevada (abs.): Ground Water, v. 25, no. 5, p. 611.

Burbey, TJ., and Prudic, D.E., 1985, Simulation of regional ground-water flow in carbonate-rock aquifers of the Great Basin in Nevada, Utah, and adjacent states (abs.): Geological Society of America Abstracts with Programs, v. 17, no. 7, p. 534.

----(in press), Conceptual evaluation of regional ground-water flow in the carbonate-rock province of the Great Basin, Nevada, Utah, and adjacent states: U.S. Geological Survey Professional Paper 1409-D.

Burkham, D.E., 1988, Methods for delineating flood-prone areas in the Great Basin of Nevada and adjacent states: U.S. Geological Survey Water-Supply Paper 2316, 20 p.

Carlton, S.M., 1985, Fish Springs multibasin flow system, Nevada and Utah: University of Nevada, Reno, Mackay School of Mines, unpublished M.S. thesis 1941, 103 p.

Carlton, S.M., and Thomas, J.M., 1986 [1987], Documentation for a digital computer model of the basin-fill aquifer in Smith Creek Valley, Lander County, Nevada: U.S. Geological Survey contribution; available only from National Technical Information Service, U.S. Department of Commerce, Springfield, VA 22161, accession number PB-87 142899 (text) and PB-87 167407 (magnetic tape).

Carman, R.L., 1985, Estimating evapotranspiration from a phreatophyte area in Smith Creek Valley, Nevada (abs): 17th Conference, Agricultural and Forest Meteorology, and Seventh Conference, Biometeorology and Aerobiology, Scottsdale, Ariz., May 1985, Program, p. 48.

-----(in press), Data on evapotranspiration in phreatophyte areas, Smith Creek Valley and Carson Desert, west-central Nevada, 1983: U.S. Geological Survey contribution; available only from National Technical Information Service, U.S. Department of Commerce, Springfield, VA 22161, accession numbers PB-89 167399 (text) and PB-89 167407 (magnetic tape). 
Carman, R.L., and Johnson, M.E., 1986, Analysis of recharge potential at surface disruption sites, Nevada Test Site, Nevada--Study approach: Nevada Water Conference, Las Vegas, February 1986, PosterSession Display.

Crompton, E.J., Frick, E.A., and Thiel, C.M., 1988, How Nevada dealt its water in 1985: American Water Resources Association Symposium on Water-Use Data for Water Resources Management, Tucson, Ariz., August 1988, Poster-Session Display.

Dettinger, M.D., 1987, Influence of Tertiary-age extensional tectonics on present-day regional ground-water flow and discharge in southem Nevada and vicinity (abs): Geological Society of America Abstracts with Programs, v. 19, no. 6, p. 371-372.

-.---1988, Ground-water quality and geochemistry of Las Vegas Valley, Clark County, Nevada, 1981-83-Implementation of a monitoring network: U.S. Geological Survey Water-Resources Investigations Report 87-4007,69 p.

-.---(in press), Reconnaissance estimates of natural recharge to desert basins in Nevada, U.S.A., by using chloride-balance calculations: Journal of Hydrology, v. 106.

-.---(in press), Evaluation of ground-water resources in a structurally extended terrain--Geologic considerations in the eastern Great Basin, Nevada and Utah (abs.): American Geophysical Union, EOS, v. 69 , no. 44 .

Dettinger, M.D., and Van Denburgh, A.S., 1988, U.S. Geological Survey ground-water studies in Nevada: U.S. Geological Survey Open-File Report 88-119, 2 p. (Water Fact Sheet).

Duffrin, B.G., Berger, D.L., and Schaefer, D.H., 1985, Principal facts for gravity stations in the Humboldt House geothermal area, Pershing County, Nevada: U.S. Geological Survey Open-File Report 85-162, 11 p.

Emme, D.H., 1986, Aqueous geochemistry and environmental isotope hydrology of the Upper Meadow Valley Wash area, southeastern Nevada: University of Nevada, Reno, unpublished M.S. thesis, 90 p.

Fischer, J.M., 1988, Streamflow infiltration and ground-water recharge through the unsaturated zone at Vicee Canyon, Nevada: University of Nevada, Reno, unpublished M.S. thesis, 100 p.

----(in press), Hydrogeology of the near-surface unsaturated zone adjacent to the disposal site for lowlevel radioactive waste near Beatty, Nevada, in Bedinger, M.S., ed., Geologic aspects for siting and design of low-level radioactive waste isolation: U.S. Geological Survey Circular.

Fischer, J.M., and Nichols, W.D., 1986, Beatty, Nevada, in Dinwiddie, G.A., and Trask, N.J., eds., U.S. Geological Survey research in radioactive waste disposal--Fiscal years 1983, 1984, and 1985: U.S. Geological Survey Water-Resources Investigations Report 87-4009, p. 87-88.

Flagg, V.E., Moosburner, Otto, and Katzer, Terry, 1985, Water-related scientific activities of the U.S. Geological Survey in Nevada, fiscal years 1983-85: Carson City, Nev., U.S. Geological Survey, 64 p.

Frick, E.A., 1985, Quantitative analysis of groundwater flow in valley-fill deposits in Steptoe Valley, Nevada: University of Nevada, Reno, unpublished M.S. thesis, $192 \mathrm{p}$. 
Frick, E.A., 1987, Geographical Information System for interpreting and displaying geochemistry of soil, shallow aquifer material, and ground water in the Carson River basin, Nevada and California--Project objective and plans, in Abstracts of papers presented at the Geographical Information Systems Symposium, Reston, Va., June 1987: U.S. Geological Survey Open-File Report 87-314, p. 32-33.

Frick, E.A., and Carman, R.L., (in press), Nevada water supply and demand, in Moody, D.W., and Chase, E.B., compilers, National water summary 1987--Hydrologic events and water supply and demand: U.S. Geological Survey Water-Supply Paper 2350.

Frisbie, H.R., La Camera, R.J., Riek, M.M., and Wood, D.B., 1984, Water-resources data for Nevada, water year 1983: U.S. Geological Survey Water-Data Report NV-83-1, 328 p.

----1985, Water-resources data for Nevada, water year 1984: U.S. Geological Survey Water-Data Report NV-84-1, $247 \mathrm{p}$.

----1985 [1988], Water-resources data for Nevada, water year 1985: U.S. Geological Survey Water-Data Report NV-85-1, 255 p.

Garcia, K.T., 1988, Effect of erosion-control structures on sediment and nutrient transport, Edgewood Creek drainage, Lake Tahoe Basin, Nevada, 1981-83: U.S. Geological Survey Water-Resources Investigations Report 87-4072, 65 p.

Garcia, K.T., and Carman, R.L., 1986, Water-quality characteristics and nutrient and suspended-sediment loads, Carson River and Truckee Canal, western Nevada, water year 1980: U.S. Geological Survey Water-Resources Investigations Report 85-4147, $107 \mathrm{p}$.

Gates, J.S., 1984, Hydrogeology of northwestem Utah and adjacent parts of Idaho and Nevada: Utah Geological Association Publication 13, p. 239-248.

----1987, Ground water in the Great Basin part of the Basin and Range province, westem Utah: Utah Geological Association Publication 16, p. 75-89.

Glancy, P.A., 1984, Flash flooding--A critical hydrologic process that relates man and geomorphology in western Nevada, in Lintz, Joseph, Jr., ed., Western geological excursions [in conjunction with 1984 annual meetings of Geological Society of America and affiliated societies]: University of Nevada, Reno, Mackay School of Mines, v. 3, p. 113-114.

-----1984, Aquifers near Fallon, Nevada, in Lintz, Joseph, Jr., ed., Western geological excursions [in conjunction with 1984 annual meetings of Geological Society of America and affiliated societies]: University of Nevada, Reno, Mackay School of Mines, v. 3, p. 115-117.

----1985, The Ophir Creek debris flood of May 30, 1983--A real test of geohydrologic hazard mapping (abs.): Specialty Conference on Delineation of Landslide, Flash Flood, and Debris Flow Hazards in Utah, Logan, Utah, June 1984, Proceedings, p. 195-196.

-..-1986, Geohydrology of the basalt and unconsolidated sedimentary aquifers in the Fallon area, Churchill County, Nevada: U.S. Geological Survey Water-Supply Paper 2263, 62 p. 
Glancy, P.A., 1988, Streamflow, sediment transport, and nutrient transport at Incline Village, Lake Tahoe, Nevada, 1970-73: U.S. Geological Survey Water-Supply Paper 2313, 53 p.

Glancy, P.A., and Whitney, J.W., 1986, Las Vegas Wash--Dynamic evolution of a southern Nevada drainage channel (abs.): Geological Society of America Abstracts with Programs, v. 18, no. 6, p. 615.

Guth, P.L., 1986, Bedrock geologic map of the Black Hills 1:24,000 quadrangle, Nevada: U.S. Geological Survey Open-File Report $86-438,9$ p., 2 sheets.

Hammermeister, D.P., and Walmsley, S.J., 1985, Hydrologic data for Leviathan Mine and vicinity, Alpine County, California, 1981-83: U.S. Geological Survey Open-File Report 85-160, 161 p.

Handman, E.H., 1988, Ground-water resources of Honey Lake Valley, Nevada and California: U.S. Geological Survey Open-File Report 88-306, 2 p. (Water Fact Sheet).

Harrill, J.R., 1986, Great Basin regional aquifer-system study, in Sun, R.J., ed., Regional aquifer-system analysis program of the U.S. Geological Survey--Summary of projects, 1978-84: U.S. Geological Survey Circular 1002, p. 146-151.

-.---1986, Ground-water storage depletion in Pahrump Valley, Nevada-California, 1962-75: U.S. Geological Survey Water-Supply Paper 2279, 53 p.

-.--1986, Hydrology, South Lake Tahoe quadrangle, Nevada and California: Nevada Bureau of Mines and Geology Open-File Report 86-4 [supplement to Urban Map 2Af], 4 p.

Harrill, J.R., Gates, J.S., and Thomas, J.M., (in press), Major ground-water flow systems in the Great Basin region of Nevada, Utah, and adjacent states: U.S. Geological Survey Hydrologic Investigations Atlas HA-694-C.

Harrill, J.R., Welch, A.H., and Preissler, A.M., 1984, Hydrogeologic controls on ground-water flow in Stagecoach Valley, Nevada, in Lintz, Joseph, Jr., ed., Western geological excursions [in conjunction with 1984 annual meetings of Geological Society of America and affiliated societies]: University of Nevada, Reno, Mackay School of Mines, v. 3, p. 117-120.

--.--(in press), Hydrogeochemical evidence for subsurface inflow to Stagecoach Valley, Lyon County, Nevada, in Subitzky, Seymour, ed., Selected papers in the hydrologic sciences: U.S. Geological Survey WaterSupply Paper.

Hoffman, R.J., 1986, A horizontal intragravel pipe for sampling water quality in salmonid spawning gravel: North American Journal of Fisheries Management, v. 6, p. 445-448.

-..-(in press), Chronology of diving activities and underground surveys in Devils Hole and Devils Hole Cave, Nye County, Nevada, 1950-86: U.S. Geological Survey Open-File Report 88-93.

Hoffman, R.J., and Hallock, R.J., (in press), Preliminary report of potentially toxic trace elements and pesticides in water, sediment, and biota in and near the Stillwater Wildlife Management Area, Churchill County, Nevada (abs.): Selenium IV--Agricultural Drainage and Implications for the Environment, Berkeley, Calif., March 1987, Symposium Proceedings. 
Hoffman, R.J., and Scoppettone, G.G., 1988, Effect of water quality on survival of Lahontan cutthroat trout eggs in the Truckee River, west-central Nevada and eastern California: U.S. Geological Survey WaterSupply Paper 2319, $21 \mathrm{p}$.

Katzer, Terry, 1986, Ground water hydrology, Carson City quadrangle, Nevada: Nevada Bureau of Mines and Geology Open-File Report 86-7 [supplement to Urban Map 1Af], 7 p.

----1986, Flood and related debris flow hazards, Las Vegas SE quadrangle, Nevada: Nevada Bureau of Mines and Geology Open-File Report 86-5 [supplement to Urban Map 3A1], 4 p.

-.--1986, Flood and related debris flow hazards, Las Vegas SW quadrangle [Nevada]: Nevada Bureau of Mines and Geology Urban Maps Series, Las Vegas SW Folio, Map 3Bl, scale 1:24,000.

Katzer, Terry, and Glancy, P.A., 1986, Flood and related debris flow hazards, South Lake Tahoe quadrangle, Nevada and California: Nevada Bureau of Mines and Geology Open-File Report 86-6 [supplement to Urban Map 2A1], 11 p.

Katzer, Terry, Harrill, J.R., Berggren, Gregg, and Plume, R.W., 1985, General ground-water map, Las Vegas SW quadrangle [Nevada]: Nevada Bureau of Mines and Geology Urban Maps Series, Las Vegas SW Folio, Map 3Bf, scale 1:24,000.

Katzer, Terry, and Schroer, C.V., 1986, Flood and related debris-flow hazards along principal drainages, Carson City quadrangle, Nevada: Nevada Bureau of Mines and Geology Open-File Report 86-8 [supplement to Urban Map 1A1], $12 \mathrm{p}$.

La Camera, R.J., and Browning, S.B., 1988, Data on surface-water quality and quantity, lower Edgewood Creek basin, Douglas County, Nevada, 1984-85: U.S. Geological Survey Open-File Report 87-565, 18 p.

La Camera, R.J., Hoffman, R.J., Nowlin, J.O., Smith, L.H., and Lima, S.M., 1985, Data on surface-water quality and quantity, Truckee River system, Nevada and California, 1979-81: U.S. Geological Survey Open-File Report 84-238, 189 p.

Lico, M.S., Welch, A.H., and Hughes, J.L., 1986, Hydrologic, lithologic, and chemical data for sediment in the shallow alluvial aquifer at two sites near Fallon, Churchill County, Nevada, 1984-85: U.S. Geological Survey Open-File Report 86-250, 43 p.

----1987, Geochemistry of ground water in the shallow alluvial aquifer, Carson Desert, western Nevada: 8th Rocky Mountain Regional Meeting, American Chemical Society, Denver, Colo., June 1986, Proceedings, p. 89-109.

Maest, A.S., Wing, Rachel, Nordstrom, D.K., Welch, A.H., and Lico, M.S., 1986, The determination and preservation of dissolved arsenic species in high arsenic waters from Fallon, NV, and Mono Lake, CA (abs.): American Geophysical Union, EOS, v. 67, no. 44, p. 940.

Maurer, D.K., 1984, Hydrogeology of Carson Valley, Nevada, in Lintz, Joseph, Jr., ed., Western geological excursions [in conjunction with 1984 annual meetings of Geological Society of America and affiliated societies]: University of Nevada, Reno, Mackay School of Mines, v. 3, p. 127-129. 
Maurer, D.K., 1984, Major structural features of Eagle Valley, Nevada, in Lintz, Joseph, Jr., ed., Western geological excursions [in conjunction with 1984 annual meetings of Geological Society of America and affiliated societies]: University of Nevada, Reno, Mackay School of Mines, v. 3, p. 125-127.

----1985, Gravity survey and depth to bedrock in Carson Valley, Nevada-California: U.S. Geological Survey Water-Resources Investigations Report 84-4202, $20 \mathrm{p}$.

-----1986, Geohydrology and simulated response to ground-water pumpage in Carson Valley, a river-dominated basin in Douglas County, Nevada, and Alpine County, California: U.S. Geological Survey Water-Resources Investigations Report 86-4328, 109 p.

----1988, Simulated changes in ground-water flow caused by hypothetical pumping in east Carson Valley, Douglas County, Nevada: U.S. Geological Survey Open-File Report 87-765, 6 p.

----1988, Simulated changes in ground-water flow caused by hypothetical pumping in southeastern Carson City, Nevada: U.S. Geological Survey Open-File Report 87-769, 7 p.

----(in press), General hydrogeology of the Vista quadrangle [Nevada]: Nevada Bureau of Mines and Geology Urban Maps Series, Vista Folio, scale 1:24,000.

----(in press), Water-level data for Las Vegas Valley, Clark County, Nevada, 1986-87: U.S. Geological Survey Open-File Report 88-200.

Maurer, D.K., and Fischer, J.M., (in press), Recharge to the Eagle Valley ground-water basin by streamflow in Vicee Canyon, west-central Nevada: U.S. Geological Survey Water-Resources Investigations Report 88-4158.

Maurer, D.K., and Myers, C.W., (in press), Recharging the ground water in Eagle Valley, west-central Nevada, by augmenting natural streamflow in Vicee Canyon: U.S. Geological Survey Open-File Report 88-487, (Water Fact Sheet).

McBeth, P.E., Jr., 1986, Hydrogeologic significance of LANDSAT Thematic Mapper lineament analyses in the Great Basin: University of Nevada, Reno, unpublished M.S. thesis, 133 p.

McBeth, P.E., Jr., and Plume, R.W., 1986, Geophysical exploration of the southern Nevada carbonate terraine: Nevada Water Conference, Las Vegas, February 1986, Poster-Session Display.

Meder, J.L., 1984, Human history and water use in the Carson and Truckee River area, in Lintz, Joseph, Jr., ed., Western geological excursions [in conjunction with 1984 annual meetings of Geological Society of America and affiliated societies]: University of Nevada, Reno, Mackay School of Mines, v. 3, p. 130-134.

Moosbumer, Otto, 1986, Nevada surface-water resources, in Moody, D.W., Chase, E.B., and Aronson, D.A., compilers, National water summary 1985-Hydrologic events and surface-water resources: U.S. Geological Survey Water-Supply Paper 2300, p. 323-328.

----1988, Potential flood and debris hazards at Katherine Landing and Telephone Cove, Lake Mead National Recreation Area, Mohave County, Arizona: U.S. Geological Survey Water-Resources Investigations Report 87-4081, 19 p. 
Morgan, D.S., and Fischer, J.M., 1984, Unsaturated-zone instrumentation in coarse alluvial deposits of the Amargosa Desert near Beatty, Nevada: Sixth Annual Participants' Information Meeting--U.S. Department of Energy Low-Level Waste Management Program, Denver, Colo., September 1984, Proceedings, p. 617-630.

Morrin, R.H., Hess, A.E., and Paillet, F.L., 1988, Determining the distribution of hydraulic conductivity in a fractured limestone aquifer by simultaneous injection and geophysical logging: Ground Water, v. 26, no. 5, p. 587-595.

Nichols, W.D., 1987, Geohydrology of the unsaturated zone at the burial site for low-level radioactive waste near Beatty, Nye County, Nevada: U.S. Geological Survey Water-Supply Paper 2312, 57 p.

----1988, Drought duration and frequency in the north-central Great Basin, 1600-1982, and implications for water supply: Symposium on Water-Use Data for Water Resources Management, American Water Resources Association, Tucson, Ariz., August 1988, p. 479-485.

Nichols, W.D., and Akers, J.P., 1985, Water-level declines in the Armagosa Valley area, Nye County, Nevada, 1962-84: U.S. Geological Survey Water-Resources Investigations Report 85-4273, 7 p.

Nowlin, J.O., 1986, Ground-water quality in Nevada--A proposed monitoring program: U.S. Geological Survey Open-File Report 78-768, 236 p.

---1987, Modeling nutrient and dissolved-oxygen transport in the Truckee River and Truckee Canal downstream from Reno, Nevada: U.S. Geological Survey Water-Resources Investigations Report 87-4037, 512 p.

----1987, Documentation for a digital computer model of nutrient and dissolved-oxygen transport in the Truckee River and Truckee Canal downstream from Reno, Nevada: U.S. Geological Survey Open-File Report 87-554, 181 p.

Pierce, H.A., and Hoover, D.B., 1986, Results of natural-source electromagnetic methods for ground water studies near Las Vegas, Nevada: Conference and Exposition, Surface and Borehole Geophysical Methods and Ground Water Instrumentation, Denver, Colo., October 1986, Proceedings, National Water Well Association, p. 354-367.

Plume, R.W., 1984, Ground-water conditions in Las Vegas Valley, Clark County, Nevada--Part I, hydrogeologic framework: U.S. Geological Survey Open-File Report 84-130, 25 p.

----1984, Use of aeromagnetic data to define some properties of a carbonate-rock aquifer in eastern Nevada (abs.): Geological Society of America Abstracts with Programs--1984, v. 16, no. 6, p. 624.

----1985, Ground-water resources of Kyle and Lee Canyons, Spring Mountains, Clark County, Nevada: U.S. Geological Survey Open-File Report 84-438, 47 p.

---1985, Geologic features that control regional ground-water movement in the eastern Great Basin, Nevada and Utah (abs.): Geological Society of America Abstracts with Programs, v. 17, no. 7, p. 691.

----1988, Geologic features that affect the movement of recharge to ground-water basins adjacent to the central Egan Range, White Pine County, Nevada (abs.): Geological Society of America Abstracts with Programs, v. 20, no. 3, p. 221. 
Plume, R.W., (in press), Use of aeromagnetic data to define boundaries of a carbonate-rock aquifer in eastcentral Nevada, in Subitzky, Seymour, ed., Selected papers in the hydrologic sciences: U.S. Geological Survey Water-Supply Paper 2330.

Plume, R.W., and Carlton, S.M., (in press), Hydrogeology of the Great Basin region of Nevada, Utah, and adjacent states: U.S. Geological Survey Hydrologic Investigations Atlas HA-694-A, 1 sheet, scale $1: 1,000,000$.

Prudic, D.E., and Dennehy, K.F., (in press), Summary of session 1--Hydrology of low-level radioactive-waste repository sites, in Bedinger, M.S., ed., Geologic aspects for siting and design of low-level radioactive waste isolation: U.S. Geological Survey Circular.

Pupacko, Alex, La Camera, R.J., Riek, M.M., and Wood, D.B., 1988, Water-resources data for Nevada, water year 1986: U.S. Geological Survey Water-Data Report NV-86-1, 263 p.

Pupacko, Alex, La Camera, R.J., Riek, M.M., and Swartwood, J.R., (in press), Water-resources data for Nevada, water year 1987: U.S. Geological Survey Water-Data Report NV-87-1.

Robbins, S.L.. Prudic, D.E., Schaefer, D.H., and Clutsom, F.G., 1985, Principal facts and density estimates for borehole gravity stations in three water wells located in Dixie and Paradise Valleys, Nevada: U.S. Geological Survey Open-File Report 85-426, 20 p.

Rowe, T.G., and Hoffman, R.J., (in press), Wildlife kills in the Carson Sink, western Nevada, winter of 1986-87, in National water summary 1987--Hydrologic events and water-supply and demand: U.S. Geological Survey Water-Supply Paper 2350.

Savard, C.S., (in press), Hydrology of four watersheds in the carbonate-rock province, White Pine County, Nevada (abs.): 24th Annual American Water Resources Association Conference, Milwaukee, Wis., November 1988, Program.

Savard, C.S., and Morgan, C.O., 1986, Radionuclide migration studies associated with underground nuclear weapon testing, Nevada Test Site, Nevada: Nevada Water Conference, Las Vegas, February 1986, PosterSession Display.

Schaefer, D.H., 1986 [1987], Bouguer gravity anomalies, depth to bedrock, and shallow temperature in the Humboldt House geothermal area, Pershing County, Nevada: U.S. Geological Survey Miscellaneous Investigations Map I-1701, 1 sheet.

----1988, Bouguer-gravity anomaly maps of Paradise, Stagecoach, Dixie, Fairview, and Stingaree Valleys, northwestern Nevada: U.S. Geological Survey Geophysical Investigations Map GP-985, 1 sheet.

----(in press), Gravity, depth to consolidated rock, and soil temperature in the Elko area, northeastern Nevada: U.S. Geological Survey Miscellaneous Investigations Map I-1900.

Schaefer, D.H., Duffrin, B.G., and Plume, R.W., 1986, Principal facts for gravity stations in Paradise and Stagecoach Valleys, Humboldt and Lyon Counties, Nevada: U.S. Geological Survey Open-File Report 85-694, 15 p. 
Schaefer, D.H., Thomas, J.M., and Duffrin, B.G., 1984, Principal facts for gravity stations in Dixie, Fairview, and Stingaree Valleys, Churchill and Pershing Counties, Nevada: U.S. Geological Survey Open-File Report 84-586, 15 p.

Scott, W.B., and Morgan, C.O., (in press), Hydrologic activities of the U.S. Geological Survey in support of the radionuclide migration program, Nevada Test Site, Nye County, Nevada, fiscal year 1986: U.S. Department of Energy Summary Report for 1986.

Smith, R.L., and Carswell, W.J., Jr., 1987, Closure [to Paper 19246, "Average annual fulfillment of instream uses"]: Journal of Water Resources Planning and Management, v. 113, no. 3, p. 446-448.

Smith, W.P., 1986, Reconstruction of precipitation in northeastern Nevada using tree rings, 1600-1982: Journal of Climate and Applied Meteorology, v. 25, no. 9, p. 1255-1263.

Thodal, C.E., (in press), Data on ground-water quality, Carson Valley and Topaz Lake areas, Douglas County, Nevada, for year ending September 1986: U.S. Geological Survey Open-File Report 88-453.

Thomas, J.M., (in press), Delineation of regional ground-water flow systems in southem Nevada using isotopic and chemical data (abs): Geological Society of America Abstracts with Programs, v. 20, no. 7.

Thomas, J.M., Carlton, S.M., and Hines, L.B., (in press), Ground-water hydrology and simulated effects of development in Smith Creek Valley, a hydrologically closed basin in Lander County, Nevada: U.S. Geological Survey Professional Paper 1409-E.

Thomas, J.M., and Hoffman, R.J., 1988, Nevada ground-water quality: U.S. Geological Survey Open-File Report 87-0738, 8 p.

Thomas, J.M., Mason, J.L., and Crabtree, J.D., 1986, Ground-water levels in the Great Basin region of Nevada, Utah, and adjacent states: U.S. Geological Survey Hydrologic Investigations Atlas HA-694-B, 2 sheets.

Thomas, J.M., Welch, A.H., and Preissler, A.M., 1985, Geochemical evolution of ground water in a hydrologically closed basin, northem Basin and Range province, Nevada (abs.): Practical Applications of Ground-Water Geochemistry Conference, Banff, Canada, June 1984, Proceedings, p. 189.

-.--(in press), Geochemical evolution of ground water in Smith Creek Valley, a hydrologically closed basin in central Nevada: Applied Geochemistry.

U.S. Department of the Interior, 1985, A proposed program to study the water resources of the carbonate-rock system of eastem and southern Nevada: U.S. Department of the Interior, 14 p.

Van Denburgh, A.S., and Arteaga, F.E., 1985, Revised water budget for the Fernley area, west-central Nevada, 1979: U.S. Geological Survey Open-File Report 84-712, 17 p.

Van Denburgh, A.S., and Goerlitz, D.F., 1987, Mobility of nitrogen-bearing organic explosives wastes and related compounds in shallow ground water near Hawthorne, Nevada (abs.): Geological Society of America Abstracts with Programs, v. 19, no. 7, p. 875. 
Van Denburgh, A.S., and Schaefer, D.H., 1986, Mobility of nitrogen-bearing explosives wastes in shallow ground water near Hawthorne, Nevada (abs.): 152nd National Meeting, American Association for the Advancement of Science, Philadelphia, Penn., May 1986, Abstracts of Papers, p. 146.

Welch, A.H., and Lico, M.S., 1986, Arsenic in shallow ground water beneath an irrigated pasture in western Nevada (abs.): American Geophysical Union, EOS, v. 67, no. 44, p. 941.

----1988, Aqueous geochemistry of ground water with high concentrations of arsenic and uranium, Carson River basin, Nevada (abs.): Chemical Geology, v. 70, no. 1/2, p. 19.

----1988, Arsenic in an alluvial-lacustrine aquifer, Carson Desert, western Nevada, in Ragone, S.E., ed., U.S. Geological Survey Program on Toxic Waste--Ground-Water Contamination, October 1985, proceedings: U.S. Geological Survey Open-File Report 86-481, p. E-13 - E-18.

Welch, A.H., Lico, M.S., and Hughes, J.L., 1986, Arsenic in ground water of the western United States (abs.): Second Annual Canadian/American Conference on Hydrogeology: Hazardous Wastes in Ground Water--A Soluble Dilemma, Banff, Alberta, Canada, June 1985, Proceedings, p. 81-82.

----1988, Arsenic in ground water of the western United States: Ground Water, v. 26, no. 3, p. 333-347.

Welch, A.H., and Olmsted, F.H., 1984, Geothermal systems of western Nevada, in Lintz, Joseph, Jr., ed., Western geologic excursions [in conjunction with 1984 annual meetings of Geological Society of America and affiliated societies]: University of Nevada, Reno, Mackay School of Mines, v. 3, p. 145-146.

Welch, A.H., and Plume, R.W., 1987, Water-quality assessment of the Carson River ground-water basin, Nevada and California--Project description: U.S. Geological Survey Open-File Report 87-104, 27 p.

Welch, A.H., and Preissler, A.M., 1986, Aqueous geochemistry of the Bradys Hot Springs geothermal area, Churchill County, Nevada, in Subitzky, Seymour, ed., Selected papers in the hydrologic sciences: U.S. Geological Survey Water-Supply Paper 2290, p. 17-36.

Welch, A.H., and Williams, R.P., 1986, Data on ground-water quality for the Millett $1^{\circ} \times 2^{\circ}$ quadrangle, central Nevada: U.S. Geological Survey Open-File Report 85-648-A, 1 sheet.

-----1986, Data on ground-water quality for the Elko $1^{\circ} \times 2^{\circ}$ quadrangle, eastern Nevada: U.S. Geological Survey Open-File Report 85-648-B, 1 sheet.

-.--1986, Data on ground-water quality for the Ely $1^{\circ} \times 2^{\circ}$ quadrangle, eastern Nevada: U.S. Geological Survey Open-File Report 85-648-C, 1 sheet.

---1986, Data on ground-water quality for the Lund $1^{\circ} \times 2^{\circ}$ quadrangle, eastern Nevada: U.S. Geological Survey Open-File Report 85-648-D, 1 sheet.

---1987, Data on ground-water quality for the McDermitt $1^{\circ} \times 2^{\circ}$ quadrangle, northern Nevada: U.S. Geological Survey Open-File Report 85-648-E, 1 sheet.

----1987, Data on ground-water quality for the Lovelock $1^{\circ} \times 2^{\circ}$ quadrangle, western Nevada: U.S. Geological Survey Open-File Report 85-648-F, 1 sheet. 
Welch, A.H., and Williams, R.P., 1987, Data on ground-water quality for the Winnemucca $1^{\circ} \times 2^{\circ}$ quadrangle, central Nevada: U.S. Geological Survey Open-File Report 85-648-G, 1 sheet.

-----1987, Data on ground-water quality for the Reno $1^{\circ} \times 2^{\circ}$ quadrangle, western Nevada: U.S. Geological Survey Open-File Report 85-648-H, 1 sheet.

-----1987, Data on ground-water quality for the Walker Lake $1^{\circ} \times 2^{\circ}$ quadrangle, western Nevada and eastern California: U.S. Geological Survey Open-File Report 85-648-I, 1 sheet.

----1987, Data on ground-water quality for the Tonopah $1^{\circ} \times 2^{\circ}$ quadrangle, central Nevada: U.S. Geological Survey Open-File Report 85-648-J, 1 sheet.

-..--1987, Data on ground-water quality for the western Nevada part of the Goldfield $1^{\circ} \times 2^{\circ}$ quadrangle: U.S. Geological Survey Open-File Report 85-648-K, 1 sheet.

-----1987, Data on ground-water quality for the Caliente $1^{\circ} \times 2^{\circ}$ quadrangle, eastern Nevada: U.S. Geological Survey Open-File Report 85-648-L, 1 sheet.

----1987, Data on ground-water quality for the western Nevada part of the Death Valley $1^{\circ} \times 2^{\circ}$ quadrangle: U.S. Geological Survey Open-File Report 85-648-M, 1 sheet.

-.---1987, Data on ground-water quality for the southern Nevada part of the Kingman $1^{\circ} \times 2^{\circ}$ quadrangle: U.S. Geological Survey Open-File Report 85-648-N, 1 sheet.

Whitfield, M.S., Jr., Eshom, E.P., Thordarson, William, and Schaefer, D.H., 1985, Geohydrology of rocks penetrated by test well USW-H-4, Yucca Mountain, Nye County, Nevada: U.S. Geological Survey Water-Resources Investigations Report 85-4030, 33 p.

Wilson, W.E., 1985, Hydrologic investigations to evaluate a potential site for a nuclear-waste repository, Yucca Mountain, Nevada Test Site (abs.): Geological Society of America Abstracts with Programs, v. 17, no. 7, p. 752 .

Wood, D.B., (in press), Water-level changes associated with ground-water development in Las Vegas Valley, Nevada, 1978-79: Nevada Division of Water Resources, Information Report 30.

-----(in press), Water-level changes associated with ground-water development in Las Vegas Valley, Nevada, 1979-81: Nevada Division of Water Resources, Information Report 31. 


\section{SOURCES OF PUBLICATIONS AND INFORMATION}

Many U.S. Geological Survey products and information are available as over-the-counter sales from Public Inquiries Offices across the Nation. Included among these are:

- U.S. Geological Survey, Public Inquiries Office, 7638 Federal Building, 300 N. Los Angeles St., Los Angeles, CA 90012; telephone (213) 894-2850;

- U.S. Geological Survey, Public Inquiries Office, Bldg. 3, Room 122, 345 Middlefield Rd., Menlo Park, CA 94025; telephone (415) 323-8111, ex. 2817; and

- U.S. Geological Survey, Public Inquiries Office, Room 8105, Federal Building, 125 S. State Street, Salt Lake City, UT 84138; telephone (801) 524-5652.

Most book reports (Professional Papers, Water-Supply Papers, Bulletins, Circulars, Water-Resources Investigations Reports, and Open-File Reports) may be ordered from:

- U.S. Geological Survey, Books and Open-File Reports Section, Federal Center, Box 25425, Denver, CO 80225; telephone (303) 236-7476.

Hydrologic Investigations Atlases, Hydrologic Unit Maps, topographic maps, and other maps pertaining to Nevada are available from:

- U.S. Geological Survey, Map Distribution Section, Federal Center, Box 25286, Denver, CO 80255; telephone (303) 236-7477.

Circular 900, titled "Guide to Obtaining U.S. Geological Survey Information," is a free publication designed to help the public utilize U.S. Geological Survey resources. A copy of Circular 900 may be obtained at the Public Inquiries Offices listed above, or ordered from the Books and Open-File Reports Section (which also is listed above).

Certain reports--those having an alpha-numeric designation such as "PB-89 $167399^{\text {" }}$ at the end of the citation, annual U.S. Geological Survey Water-Data Reports (which contain all data collected and stored in the U.S. Geological Survey National Water Data Storage and Retrieval System, by state), and most WaterResources Investigations Reports released before 1982--are available from:

- National Technical Information Service, U.S. Department of Commerce, 5285 Port Royal Road, Springfield, VA 22161; telephone (703) 4874650.

The National Water Data Exchange (NAWDEX) was established to assist users of water data in identifying, locating, and acquiring needed data. NAWDEX maintains two data bases: a Water-Data Sources Directory, and a Master Water-Data Index that identifies and describes water data. These are available from:

- U.S. Geological Survey, National Water Data Exchange, 421 National Center, 12201 Sunrise Valley Drive, Reston, VA 22092; telephone (703) 648-5677. 
New reports are announced monthly in "New Publications of the Geological Survey," subscriptions to which are available upon request from:

- U.S. Geological Survey, 582 National Center, 12201 Sunrise Valley Drive, Reston, VA 22092.

Topographic, orthophotoquad, land-use, and land-cover maps, and geographic-name and geodesic-control lists pertaining to Nevada are available from:

- Earth Science Information Center, U.S. Geological Survey, 345 Middlefield Road, Menlo Park, CA 94025; telephone (415) 329-4309 or -4390 .

Reports and maps produced by the Nevada District are available for inspection in the Carson City and Las Vegas offices.

- U.S. Geological Survey, Water Resources Division, Room 224, Federal Building, 705 North Plaza Street, Carson City, NV 89701; telephone (702) 887-7600.

- U.S. Geological Survey, Water Resources Division, 1500 E. Tropicana, Suite 201, Las Vegas, NV 89119; telephone (702) 295-1770.

Additional information about Nevada District activities may be obtained from:

- Rita Carman, Public Information Officer, U.S. Geological Survey, Room 224, Federal Building, 705 North Plaza Street, Carson City, NV 89701; telephone (702) 887-7625. 